\title{
The Podocarpeae. ${ }^{1}$
}

\author{
BY \\ WALTER STILES, M.A. (Cantab.) \\ Assistant-Lecturer in Botany in the University of Leeds.
}

With Plates XLVI-XLVIII and eight Figures in the Text.

Contents.

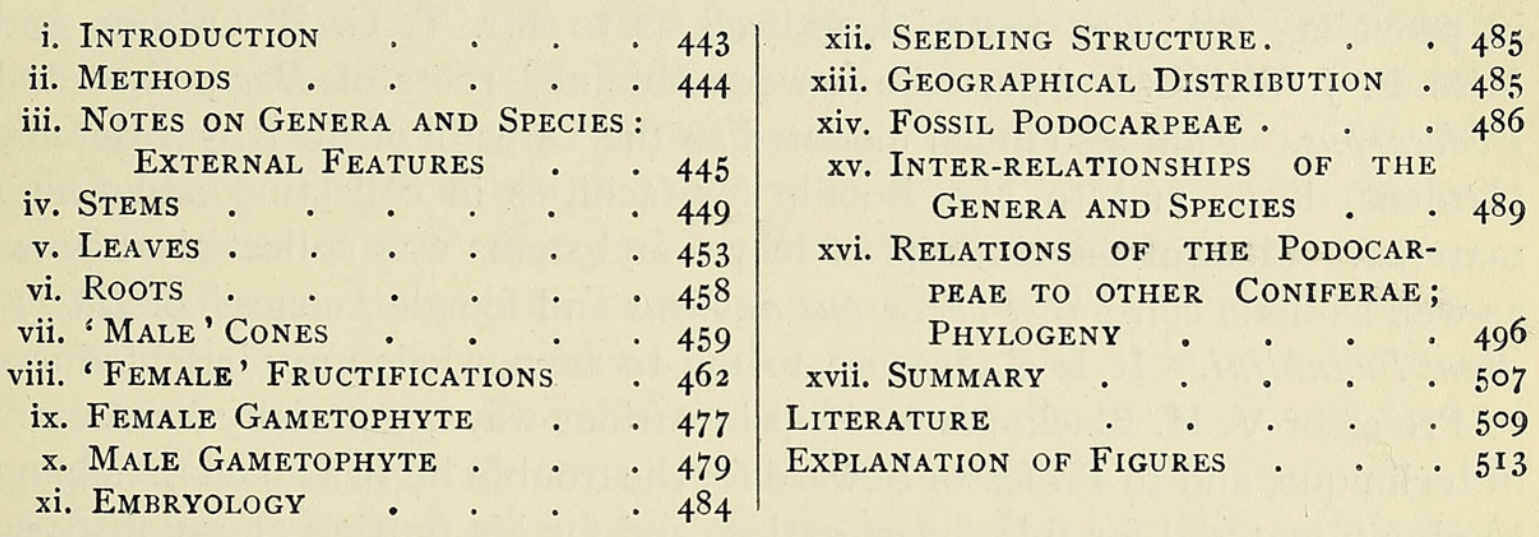

\section{i. INTRODUCTION.}

THE need for comparative researches on the Coniferae cannot be exI pressed better than in the words of Dr. Scott, who in his Presidential Address to the Linnean Society of London for the year 1910 remarked with regard to this group of plants, 'I am convinced that a thorough comparative re-investigation of the whole family will be needed before the question of their affinities can be cleared up. . . A broad synthesis is urgently needed.' ${ }^{2}$ The investigation described in the following pages is an attempt to treat of the structures met with in one of the less known orders of the Coniferae in a comparative manner. On the other hand, the investigation can by no means be described as thorough, for the difficulties of obtaining material of critical stages of some species and of obtaining material at all of others, have proved in many cases insurmountable. This is especially so in the case of gametophytic structures, where series of stages carefully fixed are essential. Owing to the kindness of Mr. W. T. Saxton it has been possible for me to examine the earlier stages of the gametophytes

1 A Walsingham Medal Essay for I 911 .

${ }^{2} \operatorname{Scott}(10)$, p. 77 .

[A.nnals of Botany, Vol. XXVI. No. CII. April, 1912.] 
of Podocarpus latifolius in material collected by him in two gorges near Cape Town on Table Mountain (Stangoolie and Orange Kloof). This material was mostly collected between October I 8 and December I7. On the latter date Mr. Saxton found that the ovules in these localities had all aborted, so that a sequence of the later stages has not been available. Dr. Marie C. Stopes has also most kindly provided material of Podocarpus macrophyllus and $P$. nagi collected by her in Tokyo. This material consisted chiefly of older ovules, which provided a sequence of later stages than those given by the material of $P$. latifolius.

I have also been enabled to examine material of Dacrydium cupressinum sent by Mr. Phillips Turner from Wellington, New Zealand, and material of Microcachrys tetragona collected in Tasmania and sent to Professor Seward by Mr. Maiden from Sydney, New South Wales. I would here record my hearty thanks to the botanists mentioned for their kindness in providing me with material, as well as to Mr. T. G. B. Osborn and Miss E. J. Welsford, from whom were obtained roots of Dacrydium and Podocarpus. I am also much indebted to the Director of the Royal Botanic Gardens, Kew, and to Mr. Boodle for facilities in collecting and fixing material. Most of the material of leaves and stems was collected at Kew, as well as male cones of Podocarpus andinus and female 'cones' of Dacrydium Franklini. It is a pleasure to me to acknowledge my indebtedness to Professor V. H. Blackman for help in various ways, especially in matters of technique, and to Professor Seward for the trouble he has taken in helping to obtain material for this investigation, and for his putting at my disposal much literature which would otherwise have been unavailable. To my colleague, Mr. J. M. Hector, I am indebted for many kindnesses.

\section{ii. Methods.}

The methods used in this investigation require no very special comment. The material collected by Mr. Turner in New Zealand was preserved in methylated spirit; that of Podocarpus nagi and P. macrophyllus, collected by Dr. Stopes at Tokyo, was preserved in dilute spirit. The material collected near Cape Town by Mr. Saxton was fixed in the mixture of mercuric chloride, picric acid, and acetic acid, as used by him in his work on the Callitrineae. The vegetative material collected at Kew was mostly fixed in methylated spirit, although some was killed in cytological fixatives. The young female fructifications of Dacrydium Franklini were fixed in the mercuric-picric-acetic mixture mentioned above, while the most suitable fixative for the male cones of Podocarpus andinus was found to be Flemming's strong fluid.

In the anatomical part of the work microtome series were used wherever possible, as well as hand sections. In a few cases it was found necessary to use the celloidin method. Safranin and anilin blue was found 
a most useful combination of stains for anatomical work, but several other combinations were also employed. For gametophytic and embryological work Benda's iron-alum haematoxylin was largely used. For thicker sections of $8 \mu$ and upwards combinations of anilin safranin with either Delafield's haematoxylin or light green were found extremely useful, owing to the transparency of the stain. For gametophytes not cytologically fixed these stains gave results equal to those obtained with iron-alum haematoxylin, and so were largely used.

\section{iii. Notes on Genera and Species: External Features.}

The division of the Coniferae into the two primary groups of Pinaceae and Taxaceae appears to date from the work of Lindley in $I 83^{1},{ }^{1}$ and has been followed by almost every writer on the Coniferae. A threefold division into Abietinae, Cupressinae, and Taxinae was earlier suggested by L. C. and A. Richard. ${ }^{2}$ The main distinction between the two divisions is in the female fructification, this being a well-defined cone in the Pinaceae, whereas cone formation tends to be imperfect in the Taxaceae. This rule is not without exception, but in the case of female cone-bearing Taxaceae there is no doubt of their affinity with other members of the group.

The later grouping of the Taxaceae into Taxeae (Taxoideae, Taxineae) and Podocarpeae (Podocarpoideae, Podocarpineae) first appears in the work of Endlicher in $1847 . .^{3}$ The differences between the Taxeae and Podocarpeae extend to the male cones as well as the female fructifications. In the first-named group the microsporophylls are peltate or sub-peltate and bear several microsporangia, whereas in the Podocarpeae they are simpler structures bearing constantly two microsporangia on their under surface. As regards their female fructifications, the Taxean ovule is erect and surrounded by two symmetrical integuments; in the Podocarpeae the ovules are generally more or less inverted, and surrounded by a symmetrical inner integument, and an outer integument which only partially surrounds the inner. Here again the distinction is not absolute, for in the genus Phyllocladus the male cone is Podocarpean, while the megasporophyll bears a single erect ovule, with two symmetrical integuments, a Taxean character. This genus has therefore caused systematists a good deal of trouble. Thus we find it placed among the Taxeae by Endlicher ${ }^{4}$ and others, removed to the Podocarpeae by Strasburger, ${ }^{5}$ and placed in a sub-family by itself by Pilger. ${ }^{6}$ Later work has tended to show more and more that its proper place is among the Podocarpeae, ${ }^{7}$ so it is considered with them in this account. The remaining genera are Podocarpus with 62 species, Dacrydium

1 Lindley ('36), p. 3 I6.

${ }^{3}$ Endlicher ('47), pp. 203, $23 \mathrm{I}$.

5 Strasburger ('72), p. 16.

7 See Robertson ('06), Young ('10), Stiles ('11).
2 Richard ('26), p. I24.

4 Endlicher ('47), p. 234 ; Eichler ('89), p. 108.

6 Pilger ('03), $\mathrm{p} .3^{8}$. 
with I6, Saxegothaea and Microcachrys each monotypic, and Pherosphaera with 2 species. ${ }^{1}$ In all genera and species a single ovule is borne in a median position on the megasporophyll. The megasporophylls may be closely aggregated in well-defined cones as in Saxegothaea and Microcachrys, the cone may be a reduced one as in Pherosphaera, a still more reduced one as in Phyllocladus, or the sporophylls may be several in number as in some species of Dacrydium and Podocarpus; lastly, they may occur singly or in pairs as in other species of these two genera. Again, the ovules may be pedicillate as in Podocarpus, or sessile on the sporophyll as in the other genera. In this case, they may be completely reversed as in Saxegothaea and Microcachrys, only partially reversed as in some species of Dacrydium, or erect as in Phyllocladus and Pherosphaera. Finally, they may have only one integument (Pherosphaera), two integuments with the outer only partially surrounding the inner, or the outer integument may be symmetrical (Phyllocladus). In spite of these differences there can now be no doubt that the forms here included form a natural family. Other evidence supporting this conclusion will be given in the course of the paper, and indeed such a view is now almost universally adopted.

The following genera and species have been examined : ${ }^{2}$

I. Saxegothaea, Lindl.

The single species $S$. conspicua, Lindl., has been described as Squamotaxus Albertiana, Senilis, but it would appear that no one but the author of the name has ever employed it. The plant is a small tree of Yew-like habit, native of the Chilian Andes, and is monoecious. A case has, however, been recorded in which some of the branches on a tree were mostly microsporangiate and others ovulate. ${ }^{3}$

2. Microcachrys, Hook. f.

The only species, $M$. tetragona, Hook. f., was for long confused with Athrotaxis, Dacrydium, and Pherosphaera. The male cones were first described by Sir W. J. Hooker in 1843 as A. tetragona, ${ }^{4}$ and again in 1845 by Sir J. D. Hooker as Microcachrys tetragona, ${ }^{5}$ the female cones then described under that name being those of Pherosphaera. Both male and female cones were described by Archer in $185^{\circ}$ as Pherosphaera. ${ }^{6}$

1 The New Caledonian genus Acmopyle (Pilger, '03, p. I I 7), with its single species $A$. Pancheri, probably belongs to this order, but so little is known of it that it seemed doubtful whether any useful purpose would be served by introducing it into this paper.

2 The nomenclature of Pilger's monograph ('03) has been followed throughout as the most recent and most complete systematic account of the Podocarpeae. Further information on external features of the species is to be found in that work. Photographs showing the habit of some species of Podocarpus and Dacrydium are given by Laing and Blackwell ('06). For photographs of Dacrydium Franklini, Pherosphaera Fitzgeraldi, Phyllocladus rhomboidalis, Podocarpus elatus, and P. spinulosus, see Baker and Smith ('10).

3 Norén ('08), p. 102.
5 Hooker, Sir J. D. ('45), p. I 49.

4 Hooker, Sir W. J. ('43), Tab. 560.

${ }^{6}$ Archer ('50), p. $5^{2}$. 
The confusion in nomenclature between the four genera mentioned above was ultimately cleared away by Sir J. D. Hooker in $\mathrm{I} 860 .^{1}$

This plant in habit is not much more than a straggling shrub found on some of the mountains of Tasmania. As regards reproductive shoots the plant is dioecious. As well as in this it differs from Saxegothaea, as far as external characters are concerned, in the form and arrangement of the leaves and in the nature of the fruit.

\section{Dacrydium, Soland.}

The first description of a plant under the generic name Dacrydium in $1786^{2}$ contains practically no mention of its structure, but is chiefly concerned with the use to which the plant is put in the making of a kind of Spruce-beer. Lambert ${ }^{3}$ appears to be the first writer to append a botanical description to the name.

This genus differs from Saxegothaea and Microcachrys in the reduction of the number of megasporophylls in the strobilus, and from Podocarpus in the absence of a stalk to the ovule, and in the freedom of the inner integument from the nucellus, and of the outer from the inner.

There is some range of habit among the sixteen species of this genus. Some, such as $D$. Kirkii, are trees reaching a height of roo feet, the majority are small trees about 20 or 30 feet high, while others are low shrubs. The species are generally dioecious, but $\mathrm{Kirk}^{4}$ describes D. laxifolium as monoecious or dioecious.

Two species of the genus have been examined in the course of this work, D. Franklini, Hook. f., and D. cupressinum, Soland. Both are forest trees, the former being the Huon Pine of Tasmania, the latter the Red Pine of New Zealand.

\section{Podocarpus, L'Hérit.}

The first plant of this genus to be given a botanical name was $P . n a g i$, (Thunb.) Pilger, which was described by Thunberg ${ }^{5}$ under the name of Myrica Nagi. Gärtner in 1778 realized that the plant belonged to a previously undescribed genus, and gave it the name of Nageia Faponica. ${ }^{6}$ Two species are confused in this description, ${ }^{7}$ so the generic name Nageia has been replaced by the later name of Podocarpus, which was first used by Labillardière ${ }^{8}$ in 1806 for the species now known as Phyllocladus aspleniifolius. In the next year L'Héritier's name Podocarpus elongatus appeared. ${ }^{9}$ L. C. and A. Richard in I 826 first gave the name Phyllocladus to what had previously been known as Podocarpus aspleniifolius. ${ }^{10}$ The Vienna Rules regarding botanical nomenclature reject the earlier name Nageia in favour

\footnotetext{
1 Hooker, Sir J. D. ('60), i, p. $35^{8}$.

3 Lambert (1803), p. 93, Tab. 4r.

5 Thunberg (1784), p. 76.

7 Pilger ('03), p. 55 .

9 Persoon (1807), p. 580.
}

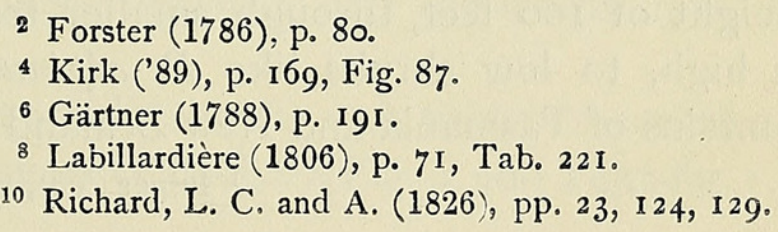


of Podocarpus, and similarly the name Podocarpus as it was first used in I806 is replaced by the later name Phyllocladus.

The chief character distinguishing Podocarpus from other genera is to be found in the greater extent to which fusion of parts has taken place in the female reproductive structures. Whereas in the genera already noticed the outer integument is to a great extent separate from the inner, which is itself separate from the nucellus, in Podocarpus the fusion of these parts is always more or less complete. In all the species of this genus also the ovule is not sessile on the megasporophyll, but is borne in an inverted position at the end of a short stalk, so that the micropyle faces towards the base of the stalk. For the upper part of its length the stalk is fused with the integuments, so that it is impossible to define the limits of the stalk and of the outer integument.

Pilger ${ }^{1}$ divides the genus into five sections :

I. Dacrycarpus, in which the fusion of parts has included the megasporophyll, which is connate with the ovulate structure. This has taken place in none of the following sections.

2. Microcarpus, in which the leaves are squamiform.

3. Nageia, where the leaves are plurinerved.

4. Stachycarpus, with linear or lanceolate leaves, but when in fruit without a fleshy receptacle formed by the fusion and swelling up of the sporophylls. In two species, $P$. andinus and $P$. spicatus, the megasporangiate strobilus consists of a branch bearing about eight megasporophylls separated by appreciable internodes. The other species of the section, however, are reduced in this respect like the species of other sections.

5. Eupodocarpus, with linear or lanceolate leaves and with a receptacle.

Species have been examined representative of the last three sections mentioned above ; it was not found possible to obtain for examination any but herbarium material of the three species of Dacrycarpus, or of the single species of Microcarpus. One species, P.nagi, (Thunb.) Pilger, was examined of the section Nageia; two species, $P$. andinus, Poeppig, and $P$. amarus, Blume, of the section Stachycarpus; and eleven species of the section Eupodocarpus: P.elatus, R. Br., P.spimulosus, (Smith) R. Br., P.polystachyus, R. Br., P. macrophyllus, (Thunb.) Don, $P$. neriifolius, Don, $P$. salignus, D. Don, P. Totara, A. Cunn, $P$. alpinus, R. Br., P. elongatus, (Ait) L'Hér., $P$.latifolius, (Thunb.) R. Br., and an unknown species. It is unnecessary to indicate the external features of each of these species, which are treated of at length by Pilger.

There is a wide range of habitat from tall trees like $P$. elatus reaching a height of Ioo feet, through smaller trees such as $P$. andinus, about 20 feet high, to low shrubs like $P$. alpinus and $P$. nivalis, found on the mountains of Tasmania and New Zealand respectively. 
Most species of Podocarpus are dioecious, though there are cases of monoecism in the genus. Mr. Saxton has made some interesting records when collecting material for this investigation. He found that $P$. latifolius was normally dioecious, but a single case was found of a female plant which bore a single male cone. In the locality in which this record was made male trees were found to be much more numerous than female ones.

It should be noted that $P$. neriifolius, Don, is perhaps more usually called $P$. bracteata, Blume; similarly $P$. salignus, D. Don, is possibly better known as $P$. chilinus, L. C. Rich., while $P$. Thunbergii, Hook., is the more familiar name of $P$. latifolius, (Thunb.) $\mathrm{R}$. Br. The plant which figures most in past investigations of the genus is Podocarpus chinensis, Wall. (or $P$. sinensis). Following Pilger this is $P$. macrophyllus, subsp. maki, Sieb.

Of the 63 species enumerated by Pilger, 3 are placed by that writer in Dacrycarpus, I in Microcarpus, 4 in Nageia, Io in Stachycarpus, and 34 in Eupodocarpus. The remaining II species are 'species incertae sedis', 3 of them possibly belonging to Nageia and 8 to Eupodocarpus. This fact alone shows the imperfect state of our knowledge of the genus at the present time, and it is possible that future systematic study may considerably alter the number of species.

\section{iv. Stems.}

\section{A. Primary Structure.}

The primary structure of the stem has been examined in the following species : Dacrydium Franklini, D. cupressinum, Podocarpus nagi, P. elongatus, $P$. amarus, and $P$. andinus.

A transverse section through the young stem of Podocarpus andinus is roughly circular, and shows generally about four of the decurrent leafbases (Pl. XLVI, Fig. I). There is in the stem a ring of seven or eight endarch collateral bundles. The centre is occupied by a parenchymatous pith; in the cortex is a ring of resin canals just outside the ring of bundles, one resin canal appearing just outside the phloem of each vascular bundle. In this species the resin canals of the stem are fairly large structures with a well-marked epithelial layer, and the canals are no doubt functional. The protoxylem, as usual, consists of spirally thickened elements, while the cells of the metaxylem have uniseriate bordered pits. The cortex is composed of parenchymatous cells; stone cells were not observed.

A leaf-trace arises by the division of one of the bundles, so that the two resulting bundles lie side by side in the ring. This is followed by the division of the resin canal in a similar manner. The leaf-trace and its accompanying resin canal then pass upwards and outwards into the leaf base.

Podocarpus elongatus is on the whole similar. A transverse section of the stem of this species is roughly square (Pl. XLVI, Fig. 2, and Text-fig. I, b). 
The leaf-insertion in this species is decussate, and the leaf-traces pass rather quickly out of the cortex. Each bundle, as in $P$. andinus, is furnished with a single resin canal.

In Podocarpus nagi the stem is usually oblong in transverse section owing to the decussate arrangement of the leaves and to the fusion of the leafbases with the stem (PI. XLVI, Fig. 3, and Text-fig. $1, d$ ). As in $P$. andinus there is a ring of endarch collateral vascular bundles surrounding the pith. How small these primary bundles are and how little xylem beyond protoxylem occurs in them is shown in Pl. XLVII, Fig. I8. In the pith, as well as in the cortex, stone cells are of fairly frequent occurrence. In this species they
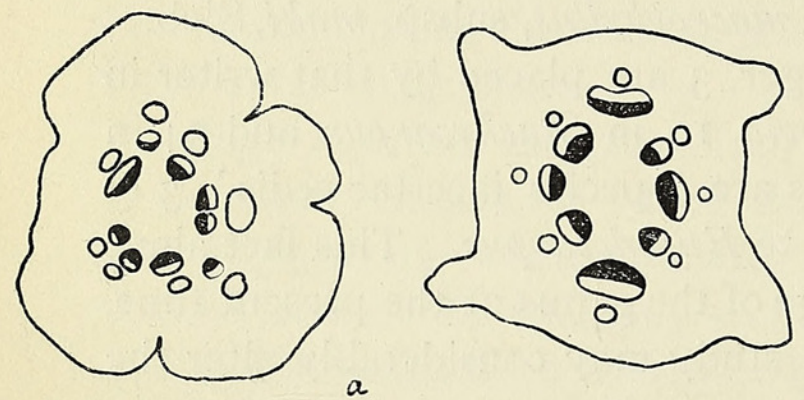

a
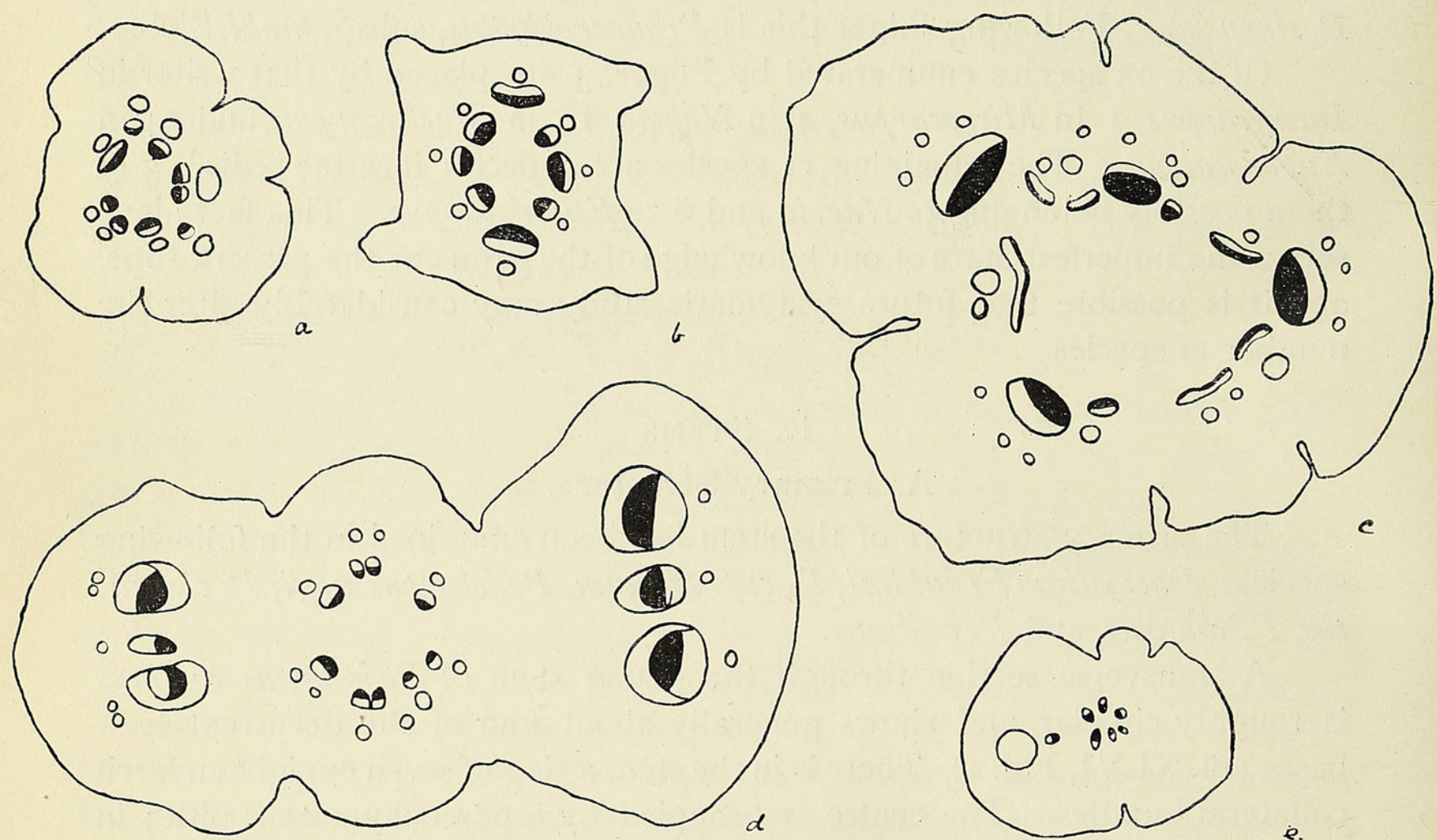

Text-FIg. I. Diagrams of transverse sections through primary stems. $\times 3^{\circ}$. a, Podocarpus andinus ; $b, P$. elongatus; $c, P$. amarus; $d, P$. nagi ; e, Dacrydium Franklini.

appear to occur singly and frequently near the xylem. The resin canals are distributed as in $P$. andinus and $P$. elongatus, but are relatively much smaller. The great peculiarity in the stem of Podocarpus nag $i$ is in the insertion of the leaf-trace. Here one of the stem bundles divides into three, the resulting bundles of the division consisting of two larger lateral ones and one smaller median one (Pl. XLVI, Figs. 3 and 4). Each bundle is accompanied by a single resin canal. These three bundles then pass upwards and outwards, as in the case of Podocarpus andinus. As far as the writer is aware, this is the only recorded case among Conifers of a leaf-trace consisting of more than two bundles, and even in Podocarpus nagi the three bundles forming the leaf-trace result from a single bundle dividing when about to pass out from 
the ring of bundles comprising the stele. Probably the condition of affairs is essentially the same as in some of the Araucarieae. ${ }^{1}$

Podocarpus amarus is essentially the same as $P$. andinus as regards the structure of the young stem. This is, as usual, a ring of bundles with a single resin canal outside each bundle. The case is, however, a little complicated as each leaf bundle is accompanied by three resin canals (Text-fig. I, c). These three canals run down into the stem with their corresponding bundle, but the two lateral ones ultimately fuse with neighbouring canals, so that the bundle is left with a solitary canal. In this stem stone cells are extremely abundant in the pith, though before secondary growth had commenced only a few solitary ones were observed in the cortex. As in $P$. nagi, the primary xylem is practically limited to the protoxylem; Pl. XLVII, Fig. I7, shows a primary bundle in the stem just as the interfascicular cambium is forming.

In the stem of Dacrydium cupressinum there is a layer of sclerenchyma outside and in contact with the phloem. In the stems examined in the course of this work the sclerenchyma was two or three layers thick. The primary medullary rays in this stem are narrow, in some cases being only two cells wide. A ring of resin canals occurs in the cortex, as in the species of Podocarpus examined.

Dacrydium Franklini is the only other species of the genus examined. There is the usual ring of vascular bundles, but unlike $D$. cupressinum, and although resin ducts are present in the leaves, canals are absent from the stem (Text-fig. I, e). The same is apparently the case in Microcachrys.

\section{B. Secondary Xylem.}

The accounts we possess of the structure of the stem in the Podocarpeae are mostly confined to accounts of the secondary wood. They are those of Bertrand ${ }^{2}$ on Podocarpus and Dacrydium (treated as a section of Podocarpus), and of Penhallow ${ }^{3}$ on Podocarpus macrophyllus. Beust ${ }^{4}$ examined Saxegothaea, and Gothan ${ }^{5}$ Saxegothaea, Dacrydium spp., and Podocarpus spp. Baker and Smith have recently published photographs of the wood of Dacrydium, Phyllocladus, and Podocarpus. ${ }^{6}$ The writer has previously examined the stem of Saxegothaea, ${ }^{7}$ and in conjunction with $\mathrm{Mr}$. Brooks that of Podocarpus spinulosus. ${ }^{8}$ Miss Gerry ${ }^{9}$ has recorded some observations on the occurrence of 'bars of Sanio' in these plants.

Bertrand's observations are largely in terms of Taxus. He found that in Podocarpus wood parenchyma was often present in greater quantity than

1 Seward and Ford ('06), p. $35 \mathrm{I}$.

3 Penhallow ('04); ('07), p. 216.

5 Gothan ('05), p. 57.

7 Stiles ('08), p. 2 I0.

9 Gerry ('10), p. II 9.
2 Bertrand ('74).

4 Beust ('84), p. 38 .

6 Baker and Smith ('10), pp. 405, 428, 439 .

8 Brooks and Stiles ('10), p. 306. 
in Taxus, that the phloem fibres early show thick walls, and that resin canals are absent from the wood or phloem. ${ }^{1}$ Bertrand's observations were limited to Dacrydium and Podocarpus, but in Saxegothaea and Microcachrys his statement with regard to the absence of resin canals in the wood and phloem holds equally well.

On the nature of the pitting, Bertrand only remarks that all the tracheides do not have spiral thickenings as in Taxus. ${ }^{2}$ Lately considerable attention has been directed to the nature and distribution of bordered pits on the walls of the tracheides. Beust ${ }^{3}$ and Gothan ${ }^{4}$ find that the pits in Saxegothaea are uniseriate, the pits being frequently in close contact and flattened above and below along the line of junction. This observation the writer was able to confirm. ${ }^{5}$ Very occasionally the pitting is for a short distance biseriate, when the pits are close together and alternate. As a result of flattening along the line of contact they have a partially hexagonal shape.

Gothan ${ }^{6}$ has observed this biseriate arrangement of the pits in the stem of Dacrydium cupressinum and two other species of the genus. I have examined the stem of Dacrydium cupressinum, but have not been able to confirm this statement. No doubt, as in Saxegothaea, the occurrence of the biseriate arrangement, at any rate in stems not many years old, is rather rare.

The writer has examined the wood of the fairly young stems of several species of Podocarpus. The pitting on the radial walls is uniseriate, and although the pits are sometimes in contact, this is not always the case, as variations in this respect may occur in the tracheides of the same section. ${ }^{7}$ That such a variation should occur is of importance when it is considered that the distribution of pitting is one of the characters used in the determination of fossil woods. On the tangential walls of the tracheides of the summer wood conspicuous and numerous large simple pits ('Eiporen') occur. ${ }^{8}$

The medullary rays throughout the order consist of parenchymatous cells only. They are only one cell wide, and in the young stems, at any rate, are not often more than five cells deep.

Gothan ${ }^{9}$ has made observations on the medullary ray pitting, a character on which he lays much stress in the determination of Coniferous woods. He finds four types of medullary ray pitting in the Podocarpeae.

I. Saxegothaea has the tangential walls of the medullary ray cells smooth, but the horizontal walls have numerous small simple pits.

1 Bertrand, 1. c.

4 Gothan ('05), p. 57.

6 Gothan, 1. c.

8 Penhallow ('07), p. 2 I7, for Podocarpus macrophyllus; Baker and Smith ('10), p. 405, Fig. 2;0, for Dacrydium Franklini.

9 Gothan ('05).

3 Peust ('84).

5 Stiles ('08), p. 210.

7 Cf. Gerry ('10), Pl. XIII, Fig. 2.

2 1. c.

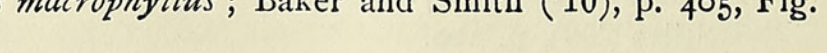


2. Typical 'Podocarpoid' pitting, consisting of smallish oval pits with a somewhat slit-like opening, occurs in Podocarpus neriifolius, $P$. salicifolius, and Dacrydium laxifolium.

3. A type characterized by large simple pits ('Eiporen') occurs in Podocarpus andinus, P. spicatus, Phyllocladus, Dacrydium Franklini, Microcachrys, and Pherosphaera.

4. A 'mixed type', with both the (2) and (3) kinds of pitting, is found in Podocarpus Sellowi, P. falcatus, Dacrydium cupressinum, and D. elatum.

\section{v. LEAVES.}

The leaves of the Podocarpeae show the usual xerophytic structure characteristic of Conifer leaves, ${ }^{1}$ but, nevertheless, the range in structure, at least as far as external characters are concerned, is probably as great as that found in any order of the Coniferae.

\section{A. External Features. ${ }^{2}$}

The leaves of Saxegothaea and of many species of Podocarpus-for example, $P$. andinus, $P$. spicatus, and $P$. ferrugineus - are in external aspect very similar to those of Taxus. They generally end in a more or less acute tip, and are narrowed at the base. From this type of leaf there can be arranged a series of leaves of various species of Podocarpus, similar in shape, but increasing in size, such as $P$. Totara, $P$. elongatus, $P$. macrophyllus, and $P$. polystachyus, culminating in the large leaves of $P$. amarus and $P$. elatus, the leaves of the last-named plant being often 12 to 15 centimetres long and a centimetre wide.

Another kind of leaf is found in the familiar type of small appressed, more or less triangular leaf, which is found in Pherosphaera, Microcachrys, many species of Dacrydium (for example, D. Franklini), and in some species of Podocarpus. In more than half of the species of Dacrydium 'juvenile' forms of leaf occur which differ from those of the adult plant in being needle-like in shape. Such 'juvenile' forms are found in $D$. cupressinum, $D$. biforme, $D$. Kirkii, D. Bidzillii, \&c. In D. cupressinum the leaves of the adult plant are shorter and flatter than those of the juvenile state, but yet are not triangular nor appressed to the stem, being rather intermediate in shape between the juvenile state and the more general adult state.

The most distinct type of leaf is found in the Nageia section of the genus Podocarpus (Pl. XLVII, Fig. 24). As is well known, the leaves in this section are comparatively wide and are traversed by a number of parallel veins; in this respect they are sharply marked off from all other species in

1 See for example Warming and Vahl ('09), p. 3 I 0.

2 A full account of the external characters of the leaves of the Podocarpeae is given by Pilger ('03), p. 3. See also the specific descriptions in that work. 
this order. The leaf of Podocarpus nagi is about $\sigma$ centimetres long by 2 centimetres wide, and often has as many as to veins. The superficial resemblance of the leaves of Nageia to those of species of Agathis has been frequently commented on, as well as the resemblance of both these types to the leaves of Cordaites.

In Phyllocladus the true leaves are reduced to scales, being replaced functionally by phylloclades.

In most of the species the leaves are arranged spirally on the axis, but in the Nageia section of Podocarpus, as well as in Microcachrys, Podocarpus vitiensis, and $P$. elongatus, a decussate or sub-decussate arrangement prevails.

\section{B. Internal Structure.}

The internal structure of the leaves of the following species has been examined: Saxegothaea conspicua, Microcachrys tetragona, Dacrydium cupressinum, D. Franklini, Podocarpus nagi, $P$. andinus, $P$. amarus, $P$. macrophyllus, $P$. elatus, $P$. polystachyus, $P$. saligmus, $P$. Totara, $P$. elongatus. In addition accounts of the structure of the following species have already been published: Podocarpus chilimus ${ }^{1}$ ( $=P$. salignus, D. Don), $P$. nagi, ${ }^{2}$ $P$. neriifolius and $P$. falcatus, ${ }^{3}$ and $P$. spimulosus. ${ }^{4}$ The leaf of Microcachrys has been described by Thomson, ${ }^{5}$ and its structure compared with that of the megasporophyll, a comparison which has brought out some interesting points. Observations on the leaves of Phyllocladus have been made by Mrs. Arber. ${ }^{6}$ As well, there is the comparative account of the structure of the leaves of Saxegothaea and Podocarpus (in which the genus Dacrydium is included) by Bertrand. ${ }^{7}$ A brief general account of the anatomy of the leaves in the Taxaceae is given by Pilger. ${ }^{8}$

From these accounts, and from investigations on the species mentioned above, it is evident that several types of leaf occur in the Podocarpeae.

I. Perhaps the commonest type of leaf is that of Podocarpus macrophyllus (Text-Fig. 2, a). In this species the leaf is 5 or 6 centimetres long and about 7 millimetres broad. On each side of the xylem of the median vascular strand is found well-developed transfusion tissue (reticulate cells of Bertrand). From either side of this stretches to the margin of the leaf the accessory transfusion tissue of Worsdell (transfusion tissue of Bertrand and hydrostereome transversal of Bernard). Descriptions and figures of both transfusion tissue and accessory transfusion tissue are given by Worsdell ${ }^{9}$ and Bernard. ${ }^{10}$ On the lower or phloem side of the vascular bundle occur three resin canals, one median with regard to the bundle, the other two, one

\footnotetext{
1 Worsdell ('97), p. 3 1 0.

3 Bernard, l. c., p. 275.

5 Thomson ( $\left.09^{2}\right)$, p. 349 .

7 Bertrand ('74).

9 Worsdell ('97).
}

\footnotetext{
2 Bernarả ('04), pp. 268, 270.

4 Brooks and Stiles ('10), p. 307.

6 Robertson ('06), p. 260.

8 Pilger ('03), p. 7 .

10 Bernard ('04).
} 
on each side of the median one, but yet distinctly underneath the phloem. These canals are small, but the epithelial cells seem to be of the normal type. ${ }^{1}$

A sclerenchymatous hypodermal layer is developed beneath the epidermis on the upper side. On the lower side this layer is only developed below the midrib, and even on the upper surface it is discontinuous. At the base of the leaf, however, hypoderm is developed all round. Stomata seem almost entirely limited to the under side of the leaf. They are sunk below the surface, as is usual in Coniferae, and are of the usual Coniferous type. There is a well-marked palisade layer below the upper epidermis and hypoderm ; the remaining mesophyll of the leaf is well provided with intercellular spaces. It is in this 'spongy' tissue that the accessory transfusion tissue is found.

The structure of the leaves of Podocarpus elatus and $P$. polystachyns seems to be essentially similar. In these species three resin canals beneath the phloem appear to be the rule. There are slight differences in the quantity of transfusion tissue, accessory transfusion tissue, and sclerenchyma, but no doubt the quantity of these is to some extent determined by external conditions. It is interesting to note that the leaves in which this type of structure has been observed are amongst the largest of the uninerved ones in the genus.

In leaves referred to Podocarpus amarus, obtained from the Royal Gardens, Kew, there are three resin canals, as in $P$. macrophyllus, but they are smaller than usual in this type, and are easily overlooked.

2. Podocarpus vitiensis, comprising Bertrand's monotypic subgenus Polypodiopsis, ${ }^{2}$ according to that author has leaves characterized by a structure different from that found in other species in the genus. The chief difference consists in the distribution of the resin canals, one under the nerve and one in the parenchyma on each side of the leaf and near the margin. The decussate arrangement of the leaves and other characteristics given by Bertrand are also found in other species.

3. In the third type of leaf there is normally a single resin duct under the vascular bundle, as, for example, in P. salignus (Text-fig. 2, $b$ ). There is also a tendency towards reduction of accessory transfusion tissue and sclerenchyma as compared with the $P$. macrophyllus type. In P. Totara the accessory transfusion tissue is not very typical, the cells being rather short, and not much lignified, intermediate in character between the mesophyll cells and typical accessory transfusion tissue. Stomata were observed on the lower surface only, while a sclerenchymatous hypoderm was observed on both sides. Podocarpus elongatus appears to have leaves with a similar internal structure, but here, as Bertrand ${ }^{3}$ correctly observed, stomata are

1 Pilger ('03, p. 8) records the frequent presence of three resin canals under the bundle in Podocarpus, but does not give the names of any species.

2 Bertrand ('74), p. 66.

${ }^{3}$ l. c., p. 60.

H h 2 
found on the upper as well as on the under surface. Pilger ${ }^{1}$ would correlate this with the presence of palisade on both sides of the leaf, but in the leaves examined by the writer palisade was very feebly developed. The development of palisade on one side or on both sides of the leaf, as well as the extent of its development, probably, as in Angiosperms, depends mostly on external conditions. Bertrand's statement that, except in $P$. elongatus, $P$. vitiensis, the Nageia section of Podocarpus, and Dacrydium, the upper face of the leaves is without stomata, ${ }^{2}$ can be accepted no more than his statement that there is constantly under each bundle a single resin canal. ${ }^{3}$ In Podocarpus andinus, for example, stomata occur on the upper as well as
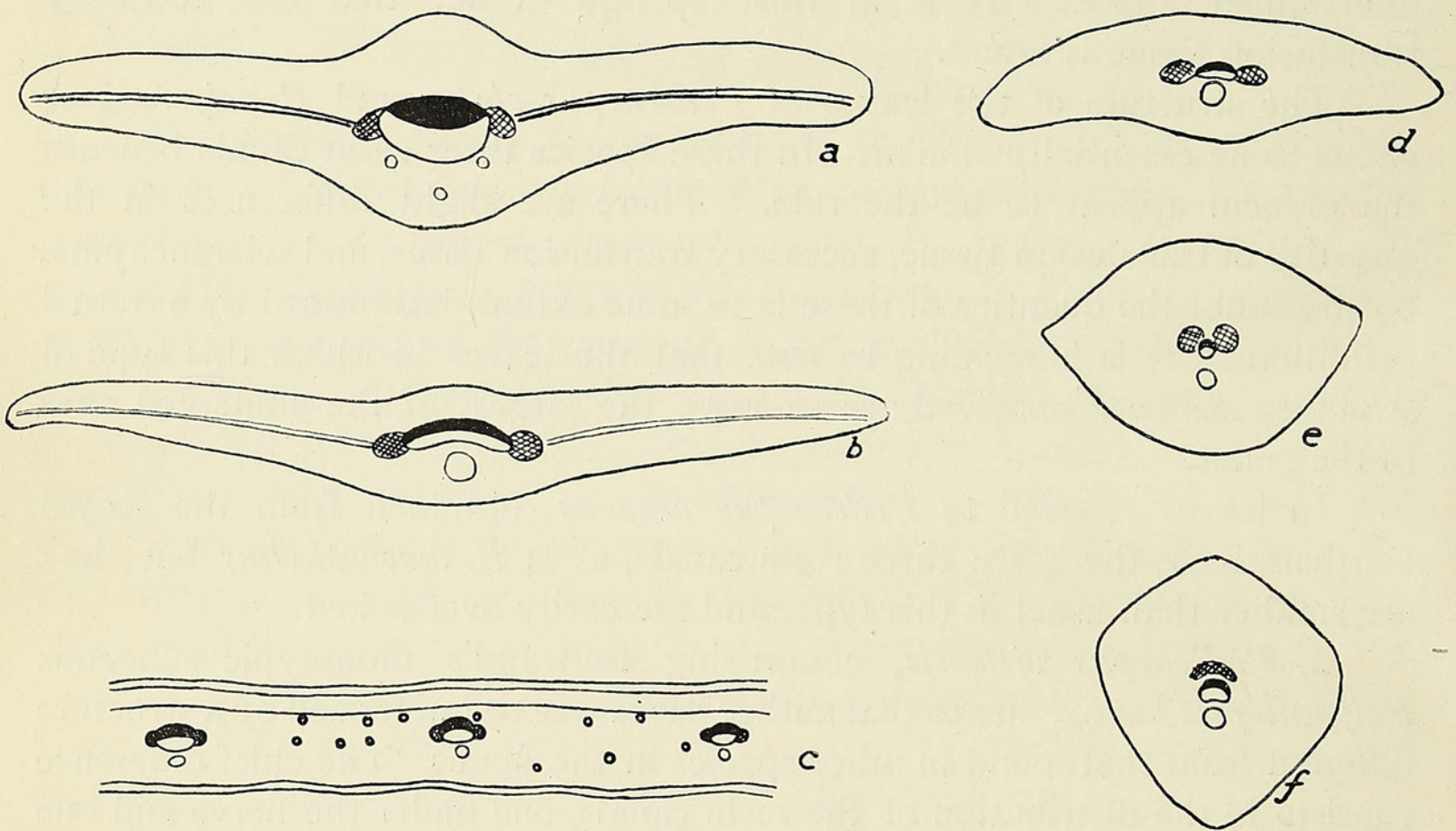

TeXT-FIG. 2. Diagrams of transverse sections of leaves of the Podocarpeae. Xylem is shown in black and transfusion-tissue is cross-hatched. In $a$ and $b$ the distribution of accessory transfusion tissue is indicated, and in $c$ the distribution of epidermis, palisade, 'spongy' tissue, and stone-cells. a, Podocarpus macrophyllus, $\times 19 ; b, P$. salignus, $\times 19 ; c, P$. nagi, $\times 36 ; d, P$. andinus, $\times 19$; $e$, Dacrydium cupressinum, $\times 36 ; f, D$. cupressinum (juvenile condition), $\times 36$.

on the under surface. ${ }^{4}$ This last species may be regarded as the extreme type of this group as regards leaf structure (Text-fig. 2, $d$ ), for in its leaves there is no trace of accessory transfusion tissue, nor is a sclerenchymatous hypoderm developed. Together with $P$. ferrugineus this species is classed by Bertrand in his section Prumnopitys, the chief characters of the section being want of both hypoderm and accessory transfusion tissue. ${ }^{5}$

4. Bertrand's characteristics of the leaf of Dacrydium are absence of accessory transfusion tissue and of differentiation of the fundamental tissue ; the constant presence of stomata on the upper surface and of hypoderm below the epidermis. ${ }^{6}$ The writer's observations on $D$. cupressinum and

\footnotetext{
1 Pilger ('03), p. 7.

2 Bertrand, 1. c.

3 1. c., cf. $P$. macrophyllus and $P$. amarus.

4 The case of Microcachrys was unknown to Bertrand.

${ }^{5}$ Bertrand ('74), p. 65 .

${ }^{6}$ l. c., p. 67 .
} 
D. Franklini quite confirm these statements. The juvenile form of leaf of D. cupressinum is tetragonal in transverse section, with a sclerenchymatous hypoderm continuous round the leaf, except in the region of the stomata. These occur in two bands towards those corners of the tetragonal leaf which are morphologically the margins. Palisade tissue is continuous all round the leaf, there being perhaps a slight development of spongy tissue in the corners corresponding to the margins.

There is a single vascular bundle with a well-marked resin canal. A well-marked sheath of parenchymatous cells surrounds the bundle and resin canals, a single layer of similar cells separating the phloem and the canal. Well-marked transfusion tissue is absent, but some lignified parenchymatous cells about the xylem probably represent it. These cells, although in the position of centripetal xylem, have exactly the appearance of parenchymatous cells, except for their lignified walls, and in this case certainly do not appear to be modified xylem-elements (Pl. XLVII, Fig. I9). The leaf of the adult form is more flattened than the juvenile form, and is not markedly tetragonal in section (Text-fig. 2,e). The structure, otherwise, is almost identical with that of the juvenile form. The stomata are in a similar position, but more numerous, while the lignified cells probably equivalent to transfusion cells occur in two rather lateral groups (Pl. XLVII, Fig. 20).

5. The leaf of Microcachrys tetragona has been described by Thomson, ${ }^{1}$ with whose account my own observations agree. There is a distinct palisade with sclerotic hypoderm on the lower surface, while hypoderm on the upper surface is wanting. The stomata, as in Dacrydium, occur on the upper surface only. The single resin canal is wholly foliar, not being carried down into the stem.

6. Phyllocladus. The writer has not had an opportunity of examining leaves of this genus. Mrs. Arber ${ }^{2}$ has described those of Ph. alpinus, Ph. trichomanoides, and Ph. rhomboidalis. They are, as would be expected in such a reduced leaf, of very simple type. On the whole they most nearly recall those of Microcachrys, except that no hypoderm or palisade is present. A single resin canal is present under each bundle. There is no differentiation of tissues in the mesophyll of the leaf. Mrs. Arber did not observe stomata in Ph. alpinus and Ph. trichomanoides, but a few were present in Ph. rhomboidalis.

7. Nageia. Of the species of the Nageia section the only one whose leaves have been examined in the course of this investigation is Podocarpus nagi. In this species no stomata were observed on the upper surface of the leaf, a character in which, according to Bertrand, it differs from other species of the section. In the leaves from Tokyo examined there is a scleren- 
chymatous hypodermal layer on both sides of the leaf. It is occasionally interrupted, and always so at the stomata.

The palisade layer under the upper hypoderm is well marked; it consists of a single layer of cells occasionally doubled. The rather compact 'spongy' tissue is about eight layers of cells thick; solitary stone cells are scattered in it. A small resin canal is present under each bundle. Accessory transfusion tissue is absent (Text-fig. 2, c).

A remarkable character presents itself at the base of the leaf in this species. It has already been stated that the leaf-trace consists of three bundles. Shortly after leaving the central cylinder of the stem a cambium forms, not only between the xylem and phloem, but also on the upper side (as regards the leaf) of the bundle as well. In this way concentric bundles are produced which consist on one side of secondary tissue only (Pl. XLVII, Fig. 2I). This state of affairs recalls that found in some of the vascular bundles of the axes of the inflorescences of Welwitschia, except that, whereas in $P$.nagi the xylem surrounds a parenchymatous area and is surrounded by phloem, in Welwitschia the concentric bundles have an amphivasal structure, with xylem surrounding the phloem. ${ }^{1}$

\section{vi. Roots.}

An exhaustive account of the structure of the roots of the Coniferales is in process of publication by Noelle ; of this account at the time of writing only the first part dealing with the Pinaceae had appeared. ${ }^{2}$ In the description of Podocarpean roots to be given here it is not intended to describe these structures in any great detail, but merely briefly to indicate the more important characteristics of the roots of the few species available to the writer.

Perhaps the most conspicuous external character of the roots of Podocarpus and Dacrydium is the presence of numerous tubercles, which are said to be caused by an ectotropic mycorrhiza. These tubercles have been mentioned by Van Tieghem ${ }^{3}$ and described by Shibata. ${ }^{4}$

In all the species examined, Dacrydium Franklini, Podocarpus macrophyllus, $P$.cupressinus, and $P$. alpimus, the primary xylem forms a rather narrow diarch plate. In this respect it agrees with the roots of the Araucarieae, ${ }^{5}$ and most of the Abietineae. ${ }^{6}$ In some of the latter, namely,

1 See, for example, Sykes ('10), pp. 192, 202. It is perhaps worthy of note in this connexion that Seward and Ford ('06, p. 338) record the presence of such a concentric leaf-trace bundle as I have described, in the cortex of a young stem of Araucaria imbricata. Seward and Ford, however, 'prefer to regard this concentric strand as a leaf-trace of unusual structure rather than attribute to what is undoubtedly an exceptional occurrence any morphological significance.'

\footnotetext{
${ }^{2}$ Noelle ('10), p. I69.

${ }^{4}$ Shibata ('02), p. 644.

3 Van Tieghem ('70), p. 195.

5 Seward and Ford ('06), pp. 343, 345; Noelle ('10), p. I 70.

${ }_{6}^{6}$ Noelle ('10), p. I 78.
} 
Pseudotsuga, ${ }^{1}$ Pseudolarix, and Abies, ${ }^{2}$ the roots are diarch or triarch, while in Pinus, as well as in the Taxodieae and Cupressineae, the roots are polyarch.

The secondary wood is composed mostly of tracheides, but woodparenchyma cells are fairly numerous. The annual rings are not always well marked, as was the case in my roots of Podocarpus cupressinus, whereas in $P$. alpinus the rings were very well marked. These differences are possibly individual rather than specific. The medullary rays are like those of the stem; they are one cell wide and wholly parenchymatous. The bordered pits on the walls of the tracheides are often contiguous; they are usually uniseriate, but a case was observed in $P$. alpinus in which there was a biseriate arrangement. Miss Gerry has recorded the presence of 'bars of Sanio' in the tracheides of the root in Dacrydium cupressinum and Saxegothaea. ${ }^{3}$ She also records the crowding of the pits in many cases.

Considerable emphasis has been laid on the value for phylogenetic and classificatory purposes of the distribution of resin canals in the root. ${ }^{4}$ In the roots of the Podocarpeae I have examined these structures were entirely absent.

\section{vii. 'MALE' CONES.}

In contrast to the megasporangiate structures, the microsporophylls of the Podocarpeae are always aggregated into cones. These are remarkably. uniform structures throughout the whole of the order, but among the different species a fairly wide variation in size is exhibited.

In Microcachrys the mature cones are only about $4 \mathrm{~mm}$. long and about $2 \mathrm{~mm}$. broad; those of Saxegothaea are about twice this length, ${ }^{5}$ while in Podocarpus andinus and $P$. spimulosus ${ }^{6}$ they may be as long as $\mathrm{I}$ to $\mathrm{I} \cdot 5 \mathrm{~cm}$. The cones of Podocarpus Totara Hallii vary from 3 to $20 \mathrm{~mm}$. in length. ${ }^{7} \quad$ A larger type of cone is found in Podocarpus latifolius, while the strobili of Podocarpus polystachyus may reach a length of $10 \mathrm{~cm}$.

In Saxegothaea and Podocarpus the male cones are borne at the apices of short pedicels, which occur either singly or two or three together in the axils of foliage leaves. In Saxegothaea one cone is usually found in the axil of a foliage leaf, though there may be two or three. ${ }^{8}$ In Podocarpus andinus the same appears to be the case. One cone in the axil is the rule in Podocarpus nivalis. ${ }^{9}$ In Podocarpus Totara Hallii, on the contrary, Burlingame reports that the cones are usually in pairs of one large and one small one. ${ }^{10}$ In Podocarpus spimulosus the number of strobili in the axil

1 Jeffrey ('05), p. 3 .

3 Gerry ('10), p. I 2 I.

5 Norén ('08), p. I02; Stiles ('08), p. 2 II.

7 Burlingame ('08), p. 162 ,

${ }^{2}$ Burlingame, 1 . c.
2 Noelle ('10), pp. 194, 205.

4 Jeffrey ('05), p. 24 ; Noelle ('10), p. 250.

${ }^{6}$ Brooks and Stiles ('10), p. $3 \circ 7$.

8 Thibout ('96), p. I79; Stiles ('08), p. 2 I . 10 1. c. 
of one leaf may vary from one to four. ${ }^{1} \quad$ The strobili of Phyllocladus are borne in clusters of 2 to 8 in the axils of scales at the tips of the lateral branches. $^{2}$ In Microcachrys, on the other hand, the male cones are terminal on an ordinary leafy shoot. ${ }^{3}$

Coulter and Chamberlain ${ }^{4}$ have remarked on the relation of leaves and strobili in the Taxaceae as being such, that if the axis were shortened, a compound strobilus would result. Although this statement does not hold generally for the Podocarpeae (as witness the case of Microcachrys), yet it is nevertheless true for Saxegothaea and all the species of Podocarpus examined by the writer. The resemblance to a raceme of the cone-bearing branch previously noticed in the case of Saxegothaea ${ }^{5}$ is even still more noticeable in the case of Podocarpus andinus (Pl. XLVI, Fig. 5).

In Microcachrys, where the foliage leaves are arranged decussately, the sporophylls are arranged in alternating whorls of four. In all other genera, as far as they have been examined, the sporophylls are spirally disposed on the cone axis. At the base of the cone occur a few small spirally arranged bracts.

The writer has only had an opportunity of examining the male cones of Saxegothaea, Microcachrys, Podocarpus andinus, P.polystachyus, P. spinulosus, and $P$. latifolius, but descriptions are also available of a few other species. These cases are, however, sufficient to show that a good deal of variation in shape and mode of attachment of sporangia exists in the order (Text-fig. 3).

In $P$. andinus each sporophyll is attached to the axis of the cone by a short narrow stalk, which terminates in the relatively large triangular upward-projecting portion ending in a broad point. The two sporangia are inserted on this on the side near the cone axis, one on each side of the stalk and partly attached to it, and are not in contact with one another (Pl. XLVI, Fig. 6, and Text-fig. 3, a). In Podocarpus latifolius the extent of fusion is greater and the sporangia are radially elongated; a tangential section of the cone shows that they are fused together for the upper half of their vertical width (Text-fig. $3, b$ ). In Saxegothaea, and presumably also in Podocarpus Totara Hallii, ${ }^{6}$ the two sporangia are fused together for the greater part of their vertical width (Text-fig. $3, c$ ). The same is the case in Microcachrys, but here a large cavity is present between the two sporangia and below the phloem of the vascular bundle (Text-fig. $3, d$ ). In Saxegothaea the line of dehiscence of the sporangium is transverse, ${ }^{7}$ and transverse dehiscence of the sporangium of Dacrydium cupressinum is figured by Richard and by Lambert, ${ }^{8}$ and described for $D$. elatum and

\footnotetext{
1 Brooks and Stiles ('10), p. 307.

3 Thomson ('091), p. 26, Pl. I, Pl. II, Figs. I and 2.

4 Coulter and Chamberlain, 1. c. 5 Lindley ('51).

6 Burlingame ('08), Pl. VIII, Fig. 6.

7 Stiles ('08), p. 2 I 2.

8 Richard ('26), Pl. II, Dacrydium cupressinum, Fig. K; Lambert ('32), Tab. 69.
} 
D. Colensoi by. Thibout, while the same is said to be the case in Podocarpus andinus, $P$. dacrydioides, and $P$. Totara. ${ }^{1} \quad$ In $P$. spinulosus ${ }^{2}$ and some other species described by Thibout ${ }^{3}$ the dehiscence is oblique. Thibout also records oblique dehiscence in Phyllocladus.

The vascular structure of the cone axis is very similar to the primary vascular structure of the stem ; that is, there is a ring of vascular bundles surrounded by a ring of resin canals, one canal outside the phloem of each bundle. Saxegothaea has traces of centripetal xylem in these bundles, ${ }^{4}$ but no such thing was found in Microcachrys or any of the species of Podocarpus examined, nor is any recorded in the case of Phyllocladus. ${ }^{5}$ No canals are present in the cone axis of Microcachrys.

The sporophyll trace originates in the same way as the leaf-trace;
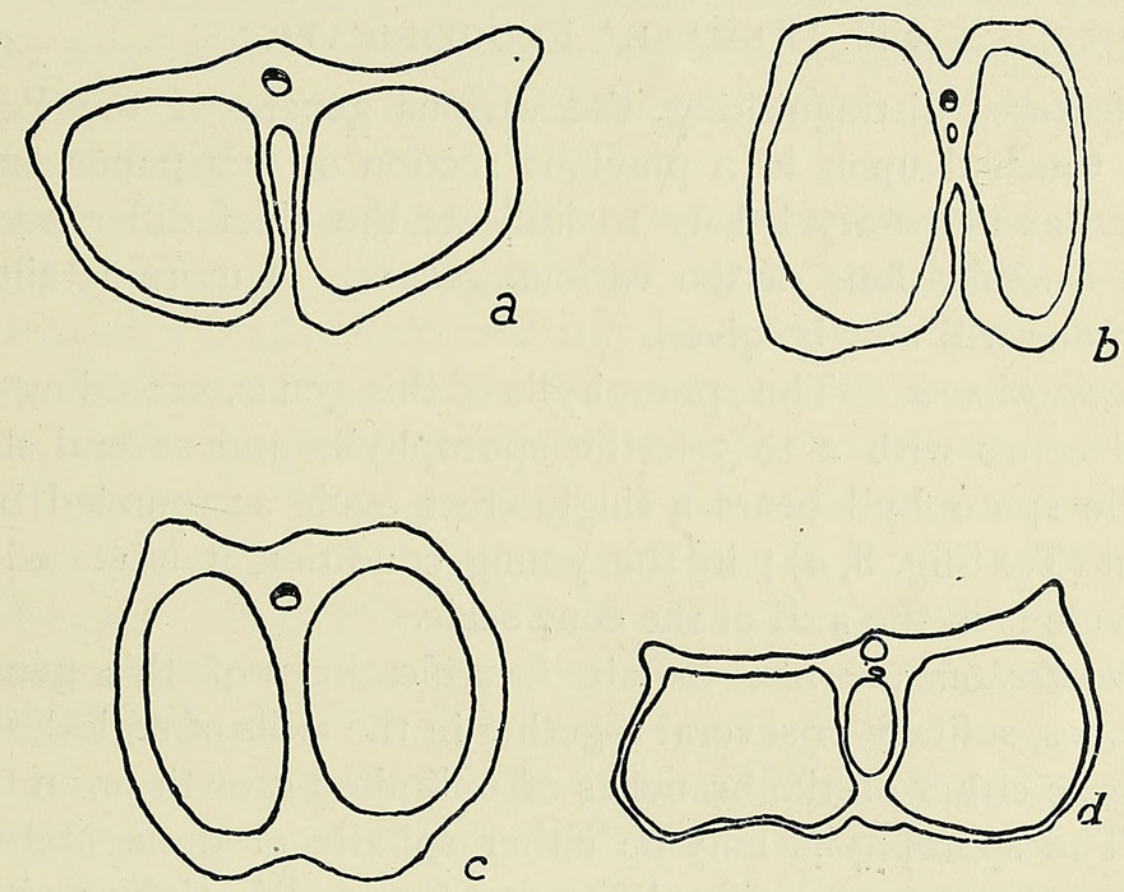

TeXT-FIG. 3. Transverse sections throngh microsporophylls. a, Podocarpus andinus, $\times 3^{2}$; b, P. latifolius, $\times 3^{2} ; c, P$. Totara Hallii (after Burlingame); $d$, Microcachrys, $\times 3^{2}$.

that is, by the division of a single bundle into two which lie side by side in the ring of bundles, above which point one of them passes out into the sporophyll. The resin canal divides similarly, and in Saxegothaea, ${ }^{6}$ Podocarpus spinulosus, ${ }^{7}$ and $P$. latifolius a canal passes into the sporophyll; in Podocarpus andinus, however, the canal does not enter the sporophyll.

The single vascular bundle in the sporophyll consists of a few xylem and phloem elements which require no special comment; in the terminal lamina the bundle ends in a development of transfusion tissue.

1 Thibout ('96), p. I 7o.

3 Thibout ('96) p. I 7 I.

${ }^{3}$ Robertson ('06).

7 Brooks and Stiles ('10), p. 308.
2 Brooks and Stiles ('10), p. 308.

4 Stiles ('08), p. 2 I 2.

6 Stiles ('08), p. 212. 
The development of the sporangium has not been traced in detail in any species of the order, but no doubt follows that of other Conifers. In the youngest material examined of Podocarpus andinus five layers of cells were visible outside the megaspore-mother-cells; in the mature sporangium only the remains of two layers were visible inside the sporangium wall. The latter in Saxegothaea and Podocarpus latifolius has conspicuous thickening bands on the vertical walls, but in $P$. andinus the walls are not very conspicuously thickened. In Saxegothaea ${ }^{1}$ and Podocarpus spp. the sporophyll contains cells of presumably a secretory nature with deeply staining contents which are very like those figured by Seward and Ford ${ }^{2}$ for Araucaria Rulei. In Podocarpus latifolius and $P$. andimus the terminal lamina contains a large air-space on the side below the vascular bundle.

\section{viii. 'Female' Fructifications.}

The features distinguishing the various genera of the Podocarpeae have been touched upon in a previous section of this paper, and for this purpose it was necessary briefly to indicate the chief differences between the female fructifications of the various genera. A more detailed account of these organs will now be given.

I. Pherosphaera. The sporophylls of this genus, according to Pilger, form small cones with 2 to 5 fertile sporophylls and several sterile ones. Each fertile sporophyll bears a single erect ovule surrounded by a single integument (Text-fig. 8, $a$ ); in the young condition it is stated by Pilger that the ovule is in the axil of the cone scale.

II. Phyllocladus. The female fructifications of this genus consist of small cones, solitary or several together in the axils of scale-leaves, which may be borne either on the branches of unlimited growth or on the phylloclades. ${ }^{4}$ The sporophylls may be either spirally or decussately arranged, and this is not even a specific difference, for in $P h$. alpinus, although the usual arrangement of the sporophylls is a decussate one, yet a spiral arrangement sometimes obtains. ${ }^{5}$ In this species there may be one pair or two pairs of fertile sporophylls at the base of the cone, and several upper pairs of sterile cone scales. ${ }^{6}$

Each fertile sporophyll bears a single erect ovule, which appears from one of Mrs. Arber's figures to be borne in the axil of the sporophyll. ${ }^{7}$ When young the ovule is surrounded by a single integument, and the resemblance to Pherosphaera is thus striking (Text-fig. 8, $b$ ). Later a symmetrical outer integument (the aril) arises round the inner, and in the older seed forms a papery cup. The inner integument appears to differentiate into

1 Stiles ('08), p. 212 , Fig. 29.

3 Pilger ('03), p. 39.

2 Seward and Ford ('06), p. 356, Fig. 22, H.

5 Robertson ('06), p. 26 I.

4 1. c., p. 94 .

' l. c., Pl. XVII, Fig. 8 .

6 1. c. 
three layers: ${ }^{1}$ an outer 'fleshy' layer which does not thicken up, ${ }^{2}$ a middle hard sclerenchymatous layer, and an inner soft-celled tissue.

It would appear from Van Tieghem ${ }^{3}$ that the sporophyll and ovular vascular supplies are connected independently to the cone axis. The ovular supply terminates below the base of the nucellus in a 'tracheal platform', no strands entering the integuments. ${ }^{4}$

III. Saxegothaca. The structure of the cone of this species has already been described by several writers. ${ }^{5}$ The cones, which are borne terminally on somewhat elongated branches, are somewhat spherical in shape, and consist of about twenty cone scales. Above the foliage leaves on the conebearing shoot, and below the cone, are a number of bracts intermediate in character between the foliage leaves and the lowest of the cone scales. These latter are sterile, and are themselves intermediate between the bracts and fertile cone scales. ${ }^{6}$ Foliage leaves and megasporophylls are thus bridged over by numerous intermediate gradations. All these are spirally arranged on the shoot.

The cone scales are ovate-lanceolate or lanceolate structures, imbricate, and becoming fused together later, first at the base. Each fertile megasporophyll bears a single ovule medianly placed on the upper surface of the scale. ${ }^{7} \quad$ At the time of pollination the ovule is sunk in a cavity at the base of the scale, and is completely reversed, ${ }^{8}$ that is, the micropyle faces towards the axis of the cone. The nucellus of the ovule is surrounded by two integuments; the outer is now generally known as the epimatium. The inner integument completely surrounds the nucellus, the epimatium only partly surrounds the ovule, being present indeed on its upper surface only (Pl. XLVI, Fig. 8).

The youngest condition of the cone has been described by Norén. ${ }^{9}$ He finds the young ovule borne near the base of the scale and at right angles to it (Text-fig. 8,c), so that the micropyle faces towards the under side of the scale above. He finds the epimatium in this young state to be in close connexion with the integument; only through the subsequent growth do the outer parts of the epimatium and integument come to be free from one another. This does not support Pilger's statement ${ }^{10}$ that the

1 Robertson ('06), Pl. XVII, Fig. II.

3 Van Tieghem ('69), p. 279.

2 Young ('10), p. 85.

4 Robertson ('06), p. $26 \mathrm{I}$.

5 Pilger ('03), p. 42; Norén ('08), p. 108; Stiles ('08), p. 213 ; Thomson ('09²), p. 345; Tison ('09), p. I42.

6 The application of the term 'bract' has been limited to the reduced leaves below the cone; the 'pièces du cône' are always referred to as 'megasporophylls' or 'cone scales'. It seems best not to use the term 'bract' in regard to the latter.

7 In several cones Thomson (' $09^{2}$ ) has observed ovules borne on the lower surface of the sporophylls at the base of the cone.

8 See Norén ('08), Taf. 8, Figs. 19 and 20 ; the former of these figures is reproduced in Coulter and Chamberlain ('10), p. 327 .

9 Norén ('08), p. Iog. 10 Pilger ('03), p. 16. 
epimatium is an outgrowth of the cone scale and has no nearer connexion with the integument of the ovule, but Norén refrains from disputing it, simply stating that he does not regard the question as settled. ${ }^{1}$ In material a little older, Tison ${ }^{2}$ confirms Norén's observations on this point. Tison's observations were made on cones about three weeks before pollination. By this time the ovule is lodged in a cavity at the base of the bract. Tison states that the ovule and epimatium are borne on the upper extremity, and appear to be the prolongation and termination of a mass of tissue differentiated from that of the cone scale. This may be so, but Tison's figures, cited to support this statement, do not in my opinion confirm it. This tissue is that undergoing rapid intercalary growth, as a result of which the ovule is carried further away from the axis, and becomes completely reversed, with the micropyle facing the axis (Text-fig. 8, d). As Tison remarks, the ovule in the very young cone is probably borne erect at the base of the scale, and it is by the continued intercalary growth at the base of the scale that the ovule comes to occupy a position some distance from the axis. Thus in the stage described and figured by Norén, the ovule is about one-eighth the length of the scale from the axis; in that described by Tison it is not less than one-fifth the length of the scale away, while at the time of pollination it may be as much as, or more than, one-third of the length of the cone scale from the axis. The later appearance of the cone has been described by Lindley ${ }^{3}$ and Pilger. ${ }^{4}$ The cone scales appear to fuse into an irregularly globose fleshy mass about a centimetre long; the scales are fused together at their base, but the acute tips remain free. In this fleshy mass are included the seeds, to about the number of six, so that a large number of ovules evidently fail to develop.

The structure of the ovule itself has been most minutely described by Norén. Tison's later description is almost identical with Norén's. The nucellus for the great part of its length is free from the integument. It is not circular in transverse section, but elliptical, the longer diameter being the one transverse to the cone scale.

Before the time of pollination the nucellus grows at a greater rate than the integument and epimatium, so that by the time pollination takes place it not only completely fills the micropyle, but projects beyond it so as to form a large stigmatic surface. ${ }^{5}$ Norén has described the peculiar mode of pollination in this species. Pollen, besides falling on the nucellus itself, may get lodged in the cavity round the ovule, in which case the pollen-tube may grow over the tissues of the integument and epimatium into the micropyle. Besides the interest attaching to such a peculiar mode of pollination,

1 Norén ('08), p. Io9.

${ }^{3}$ Lindley ('51).

${ }^{2}$ Tison ('09), p. I43.

4 Pilger ('03), p. 42.

5 Tison ('08), p. I37; Norén ('08), p. I10, Figs. I9 and 20; Stiles ('08), p. 214, Fig. 3 I ; Tison ('09), p. I 43 , Figs. 8 and 9 . 
is the greater one of its being essentially similar to the condition found by Thomson ${ }^{1}$ in Agathis. As pointed out by the writer ${ }^{2}$ and by Tison, ${ }^{3}$ this nucellar expansion is similar to that occurring in Araucaria, but is much more prominent. Tison ${ }^{4}$ reports that the nucellus is covered with a sticky secretion which no doubt keeps the pollen-grains attached to the nucellus during their germination. He finds that when the pollen is shed the sporophylls of the female cones on the same plant have already closed up.

A rather remarkable phenomenon is the occurrence of cells towards the apex of the nucellus which have thickening bands on their walls and a somewhat tracheidal appearance. ${ }^{5}$ Their function is obscure, but they may serve as water-storage reservoirs.

After pollination the stigmatic expansion continues to grow for about two months. ${ }^{6}$ Norén figures an ovule a year after pollination. The extruded part of the nucellus is still conspicuous at this late stage ; fertilization had not taken place in the ovule.

The megaspore-mother-cell arises deep in the nucellus, at the level at which the nucellus and integument become free from one another. It is surrounded by 'spongy' tissue.?

Accounts of the vascular anatomy of the female fructification have been published by Thomson, Tison, and the writer. ${ }^{8}$ The accounts agree in the main, but those of Tison and the writer differ in details.

The axis of the cone contains a ring of endarch collateral vascular bundles with a resin canal outside each in the cortex (Pl. XLVI, Fig. 7). Thomson found near the base of the cone 'a few centripetal elements associated with the bundles at the sides of the gap left by the exit of the megasporophyll trace'. Similar elements were found, but rarely, in the upper part of the peduncle. ${ }^{9}$

A single bundle leaves the axis of the cone to supply the sporophyll. This bundle arises by the division of one of the bundles of the cone axis, so that the two bundles lie side by side in the ring. A little higher up the resin canal divides similarly. The sporophyll trace and its accompanying resin canal then bend upwards and outwards into the sporophyll. In the young condition observed by Thomson, the ovular supply is given off from the upper surface of the sporophyll bundle at the level of insertion of the integument. After the separation of the ovular supply from the sporophyll bundle, centripetal xylem-elements appear in connexion with the latter.

\footnotetext{
1 Thomson ('07), p. 27 I.

3 Tison ('09), p. 145.

5 Norén ('08), p. I1 2, Fig. I6; Stiles ('08), p. 214.

2 Stiles ('08), p. 2 I 4 .

4 Tison ('08), p. I37; ('09), p. I44.

7 Norén ('08), p. 1 I 4.

8. Stiles ('08), p. 215; Thomson ('09²), p. 346 ; Tison ('09), p. I47.

9 Thomson ('092), p. $34^{8}$.
} 
Later, a more complicated, and, in the lower part of the cone scale, a very variable, vascular structure occurs. Generally, the ovular supply given off from the upper surface of the sporophyll consists of about two bundles, although the number is not constant, ${ }^{1}$ with inverse orientation of xylem and phloem as compared with the sporophyll. At the same time the sporophyll bundle divides into a row consisting of a variable number of bundles; sometimes there are three, in other cases as many as five. The central bundle often divides partially, inasmuch as although the xylem separates into several groups, the phloems of the corresponding xylem groups remain joined laterally. This state of affairs was described formerly as the sporophyll bundle dividing more or less into a row of bundles, ${ }^{2}$ a description which $\mathrm{M}$. Tison has evidently misunderstood. ${ }^{3}$ The bundles on each side of the central one now bend round through two right angles so as to lie in the same line with the ovular supply given off from the upper surface of the sporophyll bundle; the end bundles of the row, however, gradually die out, often moving further away from the central bundles; these latter, generally to the number of three or four, bend round to the ovule, and fusing into two bundles just below it, enter the base of the nucellus and there terminate. ${ }^{4}$ The xylem of these bundles is almost all centripetal in its development. No resin canals accompany the ovular supply. Higher up the scale the sporophyll bundle appears more compact, the xylem masses having reunited. Centripetal xylem makes its appearance in the upper part of the scale in great quantity. The elements are short and wide and of irregular shapes, and have the appearance of transfusion tracheides. ${ }^{5}$ Near the tip of one cone scale the single resin canal accompanying the sporophyll bundle had divided into three bundles lying side by side. This is interesting when it is remembered that one type of leaf in the genus Podocarpus contains three resin canals underneath the vascular bundle.

IV. Microcachrys. The ovoid-globose cones of this genus are terminal on the branches and consist of about twenty sporophylls which are borne in alternating whorls of four; the uppermost are always sterile. These sporophylls are tetragonal in shape, and each fertile scale bears a single ovule in a median position on the upper surface. As in Saxegothaea, the ovule is completely surrounded by an integument, partially surrounding which is an epimatium.

The youngest material examined was in the megaspore-mother-cell

1 Tison ('09) gives cases in which this supply bundle is absent altogether, but such have not been observed by the writer.

2 Stiles ('08), p. 216.

3 Tison ('09), p. 150.

4 Bertrand ("78), in a paper on ovular integuments, gives a figure of the ovule in which a vascular bundle, presumably the ovular supply, extends through the greater length of the epimatium. This representation is, however, without foundation in fact.

${ }^{5}$ Stiles ('08), p. 216, Figs. 33, 34. 
stage. At this time the ovule is inserted nearer the tip of the scale than the cone axis, being about three-fifths of the length of the scale from the cone axis. It is erect at this time, the micropyle facing directly upwards (P1. XLVI, Fig. 9; Text-fig. 8,e). As in Saxegothaea, the integument and epimatium are in close connexion, and at this stage are only free from one another for about their upper half. The integument and epimatium both project a good way beyond the top of the nucellus. The integument is much longer on the side towards the cone axis and remote from the epimatium than on the other, and in every ovule examined the upper part of it had bent round through more than a right angle, so that it was actually pointing towards the scale on this side (Pl. XLVI, Fig. 9).

The single megaspore-mother-cell is seated in about the middle of the nucellus, there being about seven layers of cells above it in median section. The cells surrounding it are not much differentiated from the outer cells of the nucellus at this stage.

At a later stage examined by. Thomson, ${ }^{1}$ the ovule has become quite reversed so that the micropyle faces the cone axis.

The writer has examined a still later stage collected on mountain tops in Tasmania. The cone scales become swollen and fleshy and of a fine red colour ; they retain their individuality, not fusing together partially as in Saxegothaea. The seed is very small, being from 2 to 3 millimetres long and a little less in width ; the lower side is flat, while the upper is convex; the seed thus has the shape of a somewhat flattened tetrahedron. The seed-coat differentiates into an outer thin membranous layer and an inner, thicker, hard sclerenchymatous layer.

The vascular structure of the cone axis consists of a ring of bundles from which the sporophyll bundles arise by division as in Saxegothaea. As in the vegetative stems of this plant there are no resin canals, so there are none in the cone axis. Worsdell ${ }^{2}$ has described the vascular system of this cone scale as consisting of two distinct bundles very close together: a lower one serving the sporophyll, and an upper one serving the ovule. According to Thomson ${ }^{3}$ a single bundle leaves the cone axis and gives off a single supply bundle from its upper surface; the orientation of the xylem and phloem of the latter is inverse as compared with that of the sporophyll bundle. In the old scales I have examined, a single bundle leaves the axis of the cone, and the ovular supply appears on its upper surface very shortly after the entrance of the sporophyll supply into the sporophyll. It lies so close to the latter, however, even up to the insertion of the ovule, that ovular and sporophyll supply might be considered one bundle. Ultimately, the ovular supply bends obliquely upwards and bifurcates near the base of the ovule, the divisions entering the base of the integument. A large resin duct, or

$$
{ }^{1} \text { Thomson }\left({ }^{\prime} 09^{2}\right) \text {, p. } 349.2 \text { Worsdell ('99), p. } 53^{8} .
$$


rather resin gland, for it ends blindly in both directions, is present on the under side of the sporophyll bundle.

\section{Dacrydium.}

i. D. Franklini. The megasporangiate strobili of this plant are terminal on the branches bearing them, and consist each of a lax spike of eight or nine megasporophylls separated by conspicuous internodes. ${ }^{1}$ Each sporophyll is a small structure, in the stage examined about $1.5 \mathrm{~mm}$. long and about I mm. wide, and is somewhat triangular in shape, and bears a single ovule medianly placed on the upper surface. Strasburger, ${ }^{2}$ who has recorded some observations on this species, states that the ovule arises in the axil of the sporophyll. In the material examined by the writer the ovule was towards the tip of the sporophyll, much as in Microcachrys. In another matter the sporophyll is very reminiscent of that of the latter genus, for it contains a resin cavity which ends blindly in both directions, resin canals being absent in the cone axis as in the vegetative stem.

The ovule in the stage examined was about half-reversed; that is, its axis made an angle of about half a right angle with the cone scale, the micropyle pointing inwards. As in Saxegothaea and Microcachrys the nucellus is free from the integument for most of its length, and the epimatium only partially surrounds the integument just as in those genera. It certainly does not completely surround the integument, as Tison asserts to be the case in Dacrydium. ${ }^{3}$ The tip of the sporophyll curves up into a point just behind the epimatium, and gives much the appearance of a third integument, and in this respect again it is not unlike Microcachrys.

The axis of the fructification contains a ring of five or six small bundles, from which those of the sporophylls are given off. At about the level of the extreme base of the slightly decurrent sporophyll a resin duct appears on the phloem side of the bundle nearest the sporophyll. A very little higher up this bundle divides into three, the two lateral ones being smaller. The central bundle first passes out into the sporophyll accompanied on its under side by a resin canal, and a very little higher up the two lateral ones pass out also. These form the ovular supply and have their xylem and phloem with inverse orientation, as in Saxegothaea and Microcachrys. As in these genera also they are not accompanied by resin ducts (P1. XLVII, Fig. 22). The two ovular supply bundles terminate below the nucellus. At the stages examined the xylem of the sporophylls is very little lignified. It is noteworthy that the ovular supply bundles attach themselves laterally to the sporophyll bundle at the extreme base of the sporophyll, much as is the case with the lateral bundles of the ovular

1 For figures see Parlatore ('64), Tav. II, Figs. 40-54.

2 Strasburger ('79), p. $76 . \quad 3$ Tison ('09), p. I47. 
supply of Saxegothaea, where, however, the insertion is higher up the scale. Occasionally, in $D$. Franklini, one of the ovular supply bundles attaches itself to a bundle of the cone axis other than its own sporophyll bundle.

ii. D. cupressinum. In this species the fertile branch terminates in a few spirally arranged scales, the uppermost of which bears a single ovule. A case was observed in which there were two fertile sporophylls on the branch. The scales differ but little from the foliage leaves; they are somewhat shorter and are lanceolate rather than linear, the transition from the linear foliage leaf to the lanceolate fertile sporophyll being gradual.

On the upper surface of the sporophyll and near its base is borne an outgrowth which arches over the ovule in the form of a hood (Text-fig. 8, $f$ ). This is the epimatium, and the solitary ovule is borne on this and not on the scale itself as in Dacrydium Franklini. Owing to lack of material the position of the ovule in the very young state cannot be recorded.

The ovule itself is rather remarkable. The nucellus is a conical structure, and is completely surrounded by a very remarkable inner integument. This consists of four distinct layers: a single outer layer of sclerenchymatous cells forming a kind of epidermis; inside this a layer of anticlinally elongated cells filled with a brown tannin-like substance; a mass of very thick-walled cells inside this, which diminishes regularly in thickness from the micropyle towards the chalaza; and, finally, on the nucellus side there is a region of parenchymatous cells, which increases in thickness as the sclerenchymatous layer diminishes. The micropyle in the stage examined consisted of a very narrow tube, but this was after pollination.

The epimatium is a much larger structure than in the species already described, and, as has been already indicated, bears the ovule on its upper surface, the latter being inserted a short distance above the junction of megasporophyll and epimatium. The latter, like the inner integument, contains a good deal of sclerenchyma. As in Saxegothaea, Microcachrys, and Dacrydium Franklini, it only partially encloses the ovule. It is, however, not pressed closely against the inner integument as in those species, and in a longitudinal section through the 'strobilus' reminds one of the ovuliferous scale of Pinus rather than of a Podocarpean epimatium. There can, however, be no doubt of its homology with the latter.

The vascular system of the cone scale and axis in D. cupressinum is similar to that of $D$. Franklini. The axis below the insertion of the fertile sporophyll contains a small ring of about three vascular bundles, each with a resin canal on its outer side. One bundle of the ring divides into three bundles, the lateral ones bending round so as to lie side by side on the inside of the median bundle. Each of these bundles is provided with a resin canal. The group of three passes into the sporophyll, and the two upper ones then pass into the epimatium and terminate at the base of the ovule. 


\section{Podocarpus.}

i. Eupodocarpus. ${ }^{1}$ The early development of the female fructification has been traced by Strasburger ${ }^{2}$ in the case of Podocarpus chinensis, Wall. ( $P$. macrophyllus, subsp. maki, Sieb.). The ovulate structure is described as arising in the axil of the sporophyll, the integument as growing up round the nucellus, while the horseshoe-shaped aril arises later.

Some young fructifications of $P$. latifolius collected by Mr. Saxton yielded the youngest stages of my material. The ovular stalk is short and the ovule at its apex is almost perpendicular to the megasporophyll, and is not reversed. The integument and epimatium are only free at the tip (Pl. XLVI, Fig. I I, and Text-fig. 8, $g$ ). In this species the ovular stalk never elongates very much; by the time the reduction division takes place the ovule is, however, completely inverted (Text-fig. $8, h, k$, and cf. with $l$ ). Later the bases of the four 'cone' scales become fused together into one fleshy mass.

The ovulate structure of Podocarpus macrophyllus is like that of $P$. latifolius in general appearance, but two fertile megasporophylls are perhaps of more frequent occurrence than in that species. The fleshy receptacle is formed in this species as in the last (Pl. XLVI, Fig. 10). The seed-coat is differentiated into two layers; a harder and thicker outer layer which, however, cannot be described as woody, and a softer inner layer which cannot be aptly described as either fleshy or membranous.

The vascular structure of the female fructification has already been described by Mr. Brooks and the writer ${ }^{3}$ in the case of Podocarpus spinulosus, (Sm.) R. Br., $P$. alpinus, R. Br., and a third species. These observations have now been supplemented by further ones on $P$. macrophyllus and $P$. latifolius.

In $P$. macrophyllus, as in species previously examined, a single bundle supplies the megasporophyll, while the ovular supply below the point at which the stalk becomes free from the sporophyll consists of two vascular bundles, the xylem and phloem of which are inversely orientated as compared with the xylem and phloem of the sporophyll bundle. These two bundles, by division of one or both, give rise to a row of three or four small bundles (Text-fig. 4, $a-d$ ). They are accompanied by a row of small canals, about one canal to each bundle, though this relation is not strictly maintained. Towards the chalazal end of the ovule, if the supply bundles number four, one of the bundles at the end of the row may die out, or bend round the ovule in a tangential direction and descend towards the micropyle.

1 For figures of the female fructifications of Podocarpus chilinus, $P$. elongatus, and P. coriaceus, see Richard ('26), Pl. I ; and for photographs of these structures in P. elatus and P. spinulosus, see Baker and Smith ('10), pp. 432, 444 .

${ }^{2}$ Strasburger ('79), p. 77.

3 Brooks and Stiles ('10), p. 31 I. 
Thus at the chalazal end there are only three of the supply bundles present. Of these the median bundle bends over the top of the ovule, and in so doing divides into two (Text-fig. $4, g$ ), while the lateral bundles bend round through a right angle(Text-fig. $4, f$ ). All these bundles descend towards the micropyle,
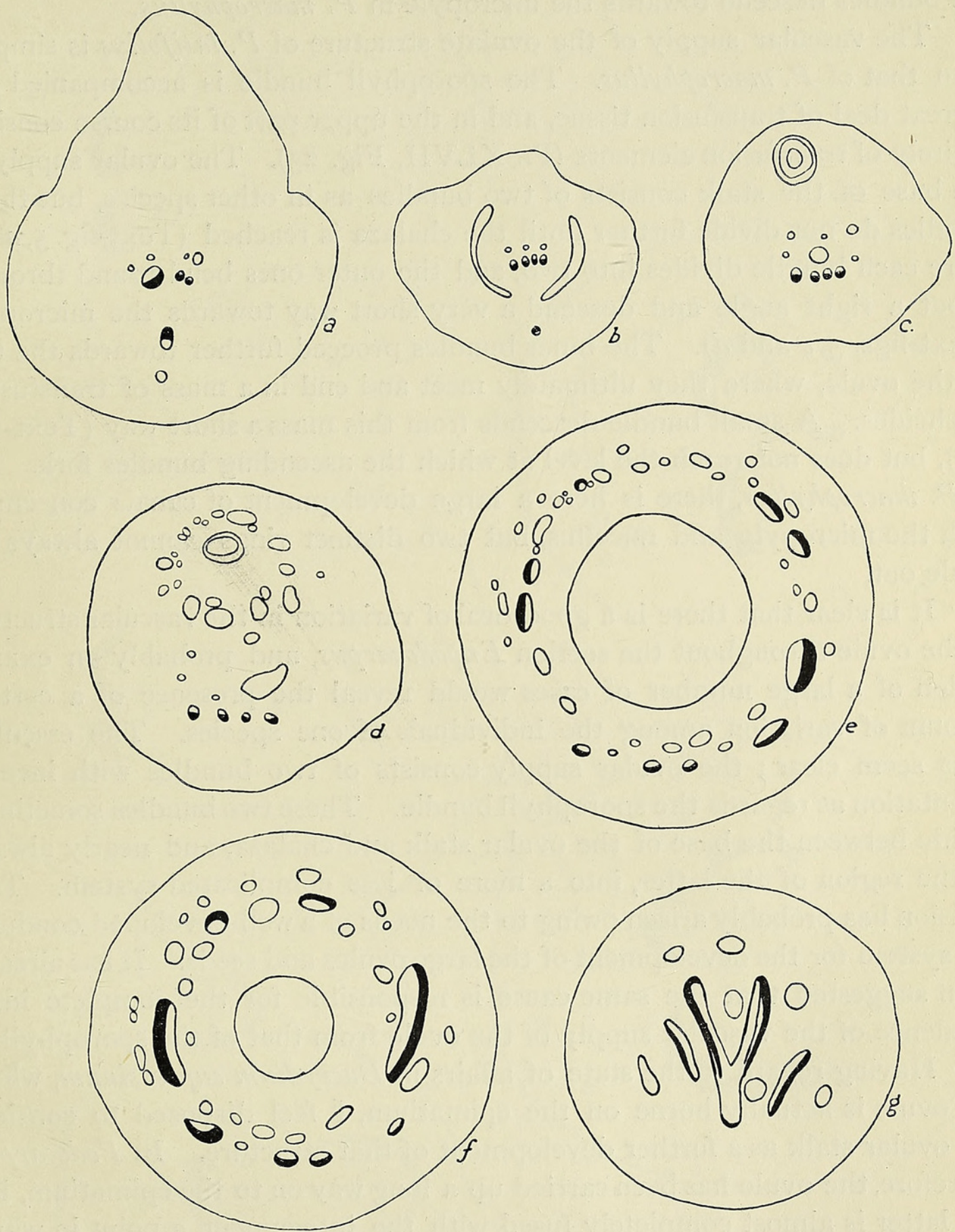

TEXT-FIG. 4. a-g. Diagrams of a series of transverse sections through the ovule of Podocarpus macrophyllus. $\times 18$.

and in so doing any single bundle may divide (Text-fig. $4, e, f$ ). They die out about half-way between the chalaza and the micropyle.

A conspicuous feature in the ovule of $P$. macrophyllus is the presence of a large number of canals in the ovule apparently unrelated to the vascular 
supply. These canals form roughly two rings concentric with the micropyle and nucellus (Text-figs. $4, d-f$ ).

The vascular supply of the ovule in $P$. macrophyllus is very similar to that of $P$. spinulosus, ${ }^{1}$ the chief difference being in the much greater distance the bundles descend towards the micropyle in $P$. macrophyllus.

The vascular supply of the ovulate structure of $P$. latifolius is simpler than that of $P$.macrophyllus. The sporophyll bundle is accompanied by a great deal of transfusion tissue, and in the upper part of its course consists entirely of transfusion elements (Pl. XLVII, Fig. 23). The ovular supply at the base of the stalk consists of two bundles as in other species, but these bundles do not divide further until the chalaza is reached (Text-fig. $5, a-c$ ). Here each bundle divides into two, and the outer ones bend round through about a right angle and descend a very short way towards the micropyle (Text-figs. 5, $c$ and $d$ ). The inner bundles proceed further towards the top of the ovule, where they ultimately meet and end in a mass of transfusion tracheides. A small bundle descends from this mass a short way (Text-fig. $5, e)$, but does not reach the level at which the ascending bundles fork. As in P. macrophyllus, there is here a large development of canals concentric with the micropyle and nucellus, but two distinct rings cannot always be made out.

It is clear that there is a good deal of variation in the vascular structure of the ovule throughout the section Eupodocarpus, and probably an examination of a large number of cases would reveal the presence of a certain amount of variation among the individuals of one species. The essential facts seem clear; the ovular supply consists of two bundles with inverse orientation as regards the sporophyll bundle. These two bundles sometimes divide between the base of the ovular stalk and chalaza, and nearly always in the region of the latter, into a more or less complicated system. This division has probably arisen owing to the needs of a well-developed conducting system for the development of the large ovules and seeds. It has already been suggested that the same cause is responsible for the complete independence of the vascular supply of the ovule from that of the sporophyll. ${ }^{2}$

Having regard to the state of affairs in Dacrydium cupressinum, where the ovule is actually borne on the epimatium, I feel disposed to consider the ovular stalk as a further development of that structure. In Podocarpus, therefore, the ovule has been carried up a long way on to the epimatium, but the latter is almost completely fused with the integument, a point in which it differs markedly from Dacrydium cupressinum.

The vascular system of the ovule of Podocarpus is therefore to be regarded as a further development from that of the more primitive Podocarpeae. In a previous paper $\mathrm{Mr}$. Brooks and the writer ${ }^{3}$ stated that there was

1 Brooks and Stiles ('10), P1. XXI, Figs. I 5-I8.

2 1. c., p. 3 I 4 . 


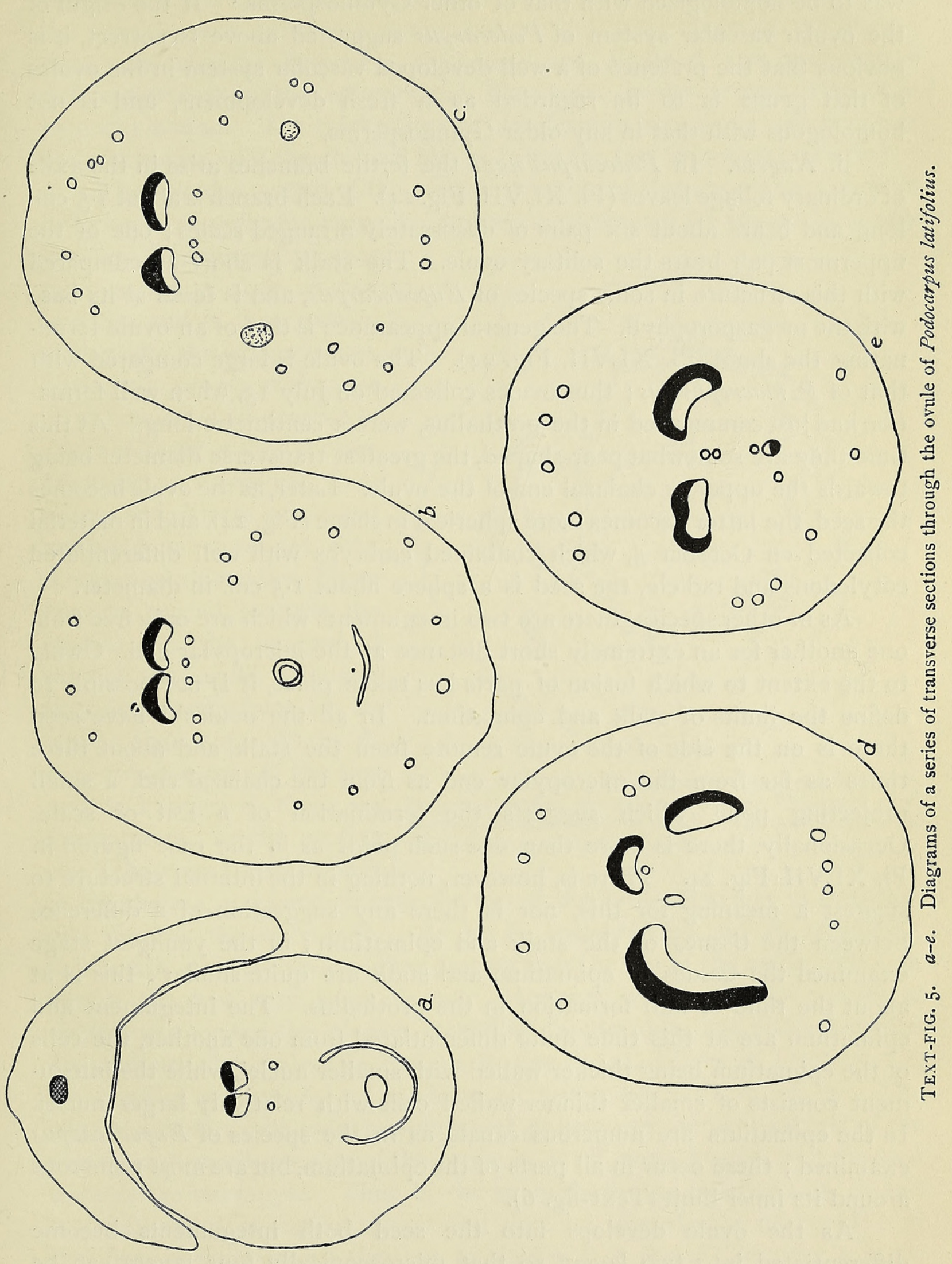


not sufficient data to decide to what extent the ovular supply in Podocarpus was to be homologized with that of other Gymnosperms. ${ }^{1}$ If the origin of the ovular vascular system of Podocarpus suggested above is correct, it is obvious that the presence of a well-developed vascular system in the ovules of that genus is to be regarded as a fresh development, and is not homologous with that in any older Gymnosperms.

ii. Nageia. In Podocarpus nagi the fertile branches arise in the axils of ordinary foliage leaves (Pl. XLVII, Fig. 24). Each branch is about I. $5 \mathrm{~cm}$. long and bears about six pairs of decussately arranged scales; one of the uppermost pair bears the solitary ovule. The stalk is short as compared with this structure in some species of Eupodocarpus, and is fused at its base with the megasporophyll. The general appearance is that of an ovule terminating the shoot (Pl. XLVII, Fig. 24). The ovule is large compared with that of P.macrophyllus; thus ovules collected on July I3, when wall formation had just commenced in the prothallus, were a centimetre long. At this time they are somewhat pear-shaped, the greatest transverse diameter being towards the upper or chalazal end of the ovule. Later, as the ovule becomes the seed, the latter becomes more spherical in shape (Fig. 24), and in material collected on October 5 , which contained embryos with well differentiated cotyledons and radicle, the seed is a sphere about $\mathrm{I} .5 \mathrm{~cm}$. in diameter.

As in other species, there are two integuments which are only free from one another for an extremely short distance at the micropylar end. Owing to the extent to which fusion of parts has taken place, it is not possible to define the limits of stalk and epimatium. In all the ovules I have seen there is on the side of the ovule remote from the stalk, and about three times as far from the micropylar end as from the chalazal end, a small projecting point which suggests the termination of a leaf or scale. Occasionally, there is more than one such point, as in the case figured in Pl. XLVII, Fig. 24. There is, however, nothing in the internal structure to suggest a meaning for this, nor is there any suggestion of a difference between the tissues of the stalk and epimatium; in the youngest stage examined the tissues of epimatium and stalk are quite similar: this is at about the time of wall formation in the prothallus. The integument and epimatium are at this time quite differentiated from one another, the cells of the epimatium being thicker walled with smaller nuclei, while the integument consists of smaller thinner walled cells with relatively larger nuclei. In the epimatium are numerous canals, as in the species of Eupodocarpus examined; these occur in all parts of the epimatium, but are most numerous around its inner limit (Text-fig. 6).

As the ovule develops into the seed both integuments become differentiated into two layers, so that microscopically four layers can be recognized in the seed-coat; a naked-eye examination, however, only ${ }^{1}$ Oliver ('03); Stopes ('04); Arber, A. ('10); Oliver and Salisbury ('11). 
reveals two layers, the outer soft semi-fleshy layer (formed from the epimatium) and the inner woody layer (formed from the integument). By the time the seed contains a young embryo the outer layers of the integument are already becoming thickened and lignified, and are clearly differentiated from the epimatium. The inner layers remain thin and parenchymatous. The thickening and lignification appear to commence at the micropylar end, the chalazal region being the last to become lignified.

The vascular system of the ovulate structure of Podocarpus nagi appears to be more complicated than that previously described for the ovule of any Conifer. The sporophyll contains a row of four or five bundles, and is thus parallel veined like the foliage leaves. The ovular supply at the base of the ovular stalk consists of a row of three or four bundles (Text-fig. 7,a) having their xylem and phloem orientated inversely as compared with the sporophyll bundles. These bundles ascend towards the chalaza on the sporophyll side of the ovule, although they may sometimes be laterally displaced. As in $P$. macrophyllus, one of the two middle bundles if there are four present, or the median one if there are three, ascends

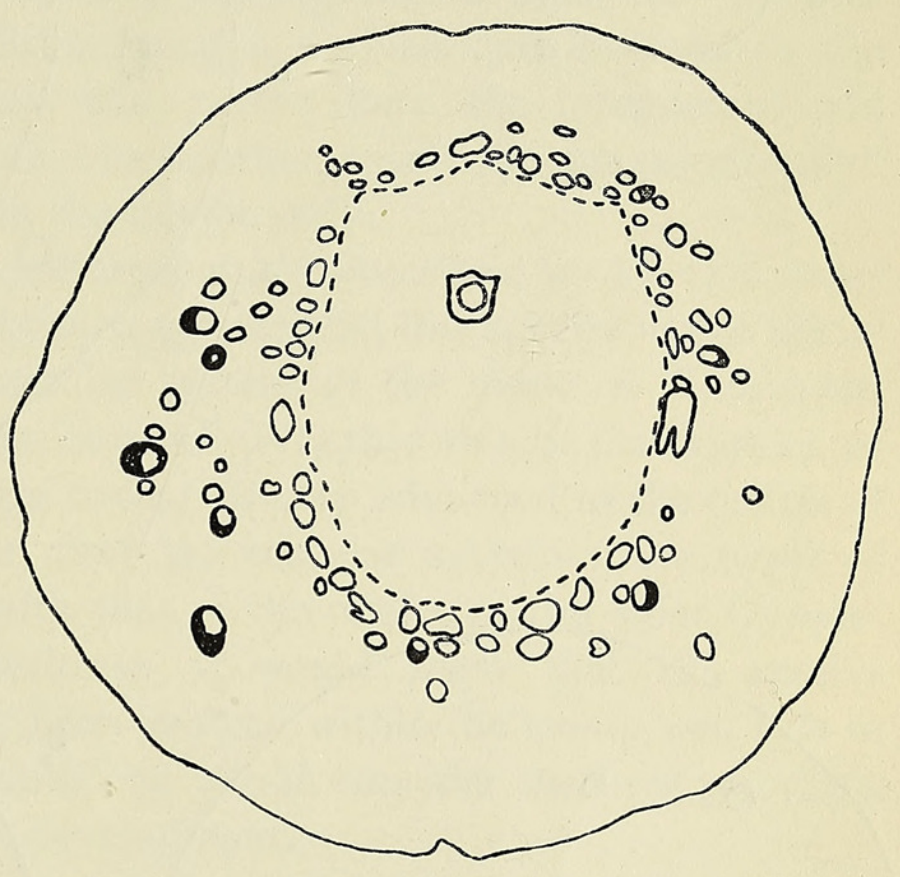

TexT-FIG. 6. Diagrammatic representation of a transverse section through an ovule of Podocarpus nagi, showing the distribution of canals. The dotted line marks the outer limit of the integument. $\times 8$.

to the chalaza, and bending over the top of the ovule descends on the other side towards the micropyle. As in $P$. macrophyllus and $P$. spinulosus, this bundle divides into two after passing over the top of the ovule, although one of the two may soon die out. However, whereas in the species of Eupodocarpus cited the median ascending bundle does not divide between the stalk and the chalaza, in $P$. nagi it may do so. Thus in Text-fig. 7,c, the bundles marked $B_{2}, B_{3}, B_{4}$, have all arisen by division of $B$. The bundles lateral to the main bundle which passes over the chalazal end of the ovule bend round the side of the ovule as in P. macrophyllus, and descend towards the micropyle. Thus in the series shown the bundles $\mathrm{A}, \mathrm{B}_{3}, \mathrm{C}$, and $\mathrm{D}$, bend round at various levels and descend towards the micropyle; in this part of their course they are marked $a, b_{3}, c$, and $d$ (Text-fig. $7, c, d$ ). As in P. macrophyllus, these descending bundles may divide. They descend a $a_{\text {most }}$ to the micropylar region (Text-fig. $7, b$ ), and in this respect differ 
from species of Eupodocarpus so far examined. In the outer layers of the integument in the young ovules there is a ring of what appear to be
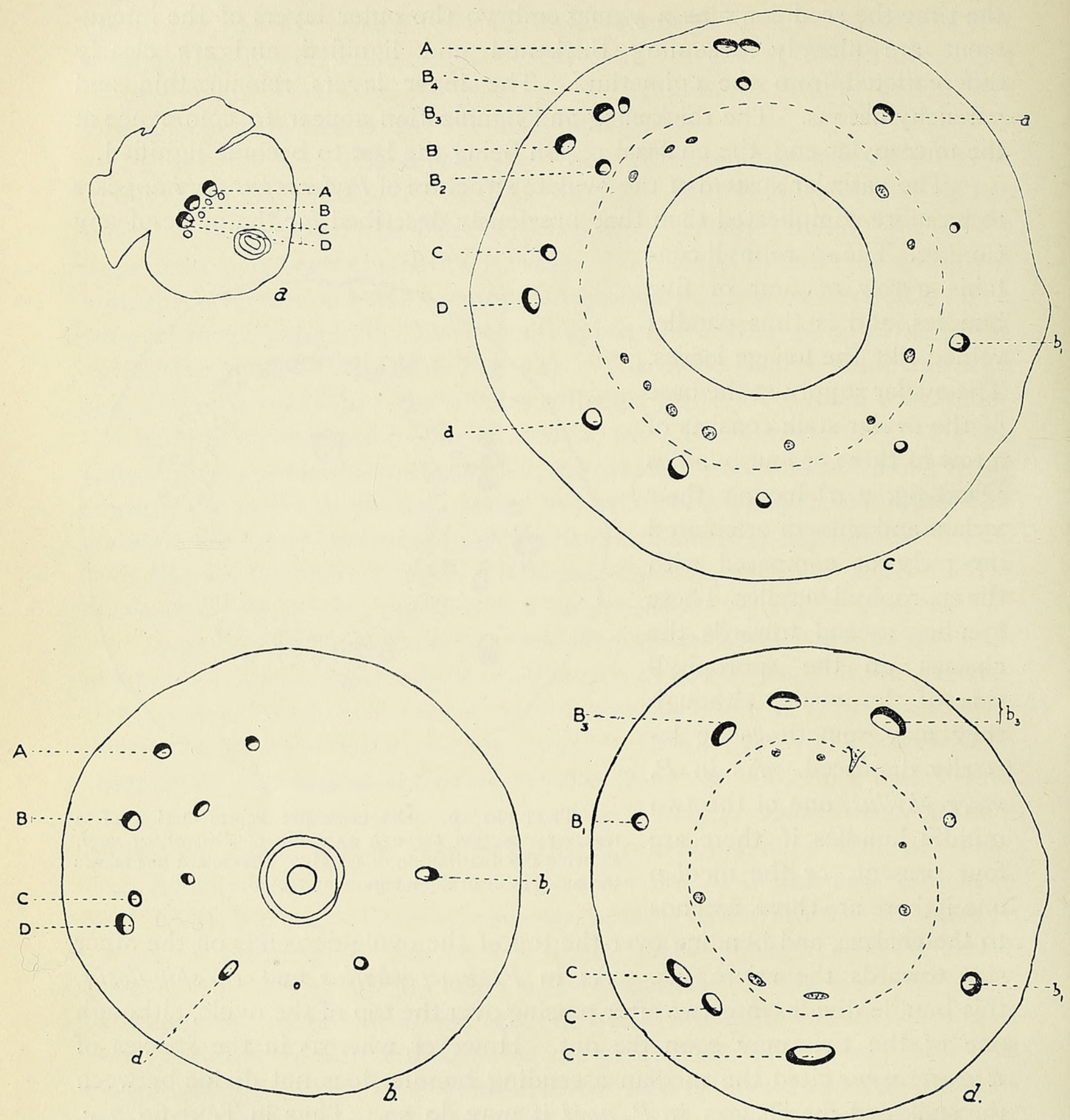

TEXT-FIG. 7. Diagrams of transverse sections through an ovule of Podocarpus nagi to show the distribution of vascular tissue. $a$, Near the micropylar end. $b$, A little higher up. $c$, Through the middle of the ovule. $d$, Towards the chalazal end. A-D, ascending vascular bundles. $a-d$, descending vascular bundles.

undifferentiated vascular bundles connected with the vascular bundles of the epimatium by means of undifferentiated or only partly differentiated strands. ${ }^{1}$ Later these strands become more noticeable, until in the old seed

1 Compare the state of affairs in Torreya, where the supply of the inner integument is similarly undifferentiated (Oliver ('03), p. 469). On general grounds, however, it does not seem possible to connect the structure of the Torreyan with that of the Nageian ovule. 
they stand out distinctly on the outside of the woody integument after removal of the softer epimatium.

The ovule of Podocarpus nagi has thus an exceedingly complicated structure, both as regards the differentiation of the seed-coat into four layers, and as regards the vascular system. Everything goes to show that this is a derived and not a primitive condition. The vascular system is extremely unlike that in the ovule of any other genus of Gymnosperms, but can be compared with that of Podocarpus macrophyllus. It is more complicated than in that species, but the ground-plan is the same, and the further development is no doubt connected with the large size of the seed. Further evidence in support of the condition being a derived one is found in the greater extent of fusion between the parts; here the integument and epimatium are scarcely free from one another, while the megasporophyll is fused for part of its length with the ovular stalk.

It is possible that this is the species vaguely described by Favre ${ }^{1}$ under the name of $P$. chinensis. It has been suggested that this species might throw light on the homology of the vascular system of the ovule of Podocarpus with that of other Gymnospermous ovules., ${ }^{2}$ Whether this be that species or not it furnishes additional evidence to that already advanced in the course of this section of the present paper, that the vascular system of the ovule of Podocarpus is not homologous with that of the ovules of the older Gymnosperms described by various writers. It would seem that the ovular structure in the Podocarpeae has been evolved within the group, and it is in the genus which on general grounds one would consider the least primitive that one finds the most complex development.

\section{ix. Female Gametophyte.}

It is with regard to the female gametophyte and embryology that the greatest gap in our knowledge of the Podocarpeae occurs. Of the female gametophyte of Pherosphaera we know nothing ; in the case of Saxegothaea, Microcachrys, and Dacrydium our knowledge is limited to a few isolated observations on the megaspore membrane. ${ }^{3}$ In Phyllocladus and Podocarpus a general outline of the gametophytic history is known in one species of each genus (Ph. sp. and $P$. coriaceus). Owing to the kindness of Dr. M. C. Stopes and Mr. Saxton I have been enabled to examine gametophytic material of two species of the Eupodocarpus section of Podocarpus (P. macrophyllus and P. latifolius), and one species of the section Nageia ( $P$. nagi $)$. The earliest stages were found in ovules of $P$. latifolius. The megaspore increases in size, and its nucleus divides, so that the free nuclei

1 Favre ('65), p. 379.

2 Brooks and Stiles ('10), p. 315 .

3 Since this paper was written the writer has published a few facts relating to the Gametophytes of Dacrydium. See Stiles ('11). 
formed by successive divisions come to lie in the parietal layer of cytoplasm surrounding the central vacuole.

During the development of the young prothallus the layers of tapetal cells come to be more sharply marked off from the outer cells of the nucellus. Wall formation was not observed, but from the disposition of the cells before the appearance of the archegonia, there can be no doubt that the ingrowing primary prothallial cells are formed as in other Conifers. $\mathrm{Up}$ to the time of formation of the archegonia the cells of the prothallus are all uninucleate; no sign of any binucleate condition was observed such as Lawson ${ }^{1}$ found in Cryptomeria.

The archegonia arise as superficial cells at the apical end of the prothallus. Coker found that these numbered from five to ten in $P$. coriaceus; there is a similar number in the case of $P$. macrophyllus, but in $P$. latifolius, in the only case examined, there were as many as fourteen archegonia, while in each of the two ovules of $P$.nagi which contained archegonia the number was nineteen. Each archegonium is surrounded by a well-defined layer of jacket cells; these are conspicuous on account of their denser cytoplasm and larger nuclei. Occasionally, in P. macrophyllus, two archegonia occur within a common jacket, a fact of interest in comparison with Phyllocladus, where the same phenomenon has been observed. In $P$. nagi, to judge from the two cases examined, the phenomenon is more marked, as many as three archegonia being surrounded by a common jacket. The distribution of the archegonia in Podocarpus is thus like that in the Abietineae and Taxeae, but shows an approach to the state found in Cunninghamia, ${ }^{3}$ where the archegonia form a ring all enclosed in a common jacket, and surrounding a central mass of sterile tissue.

Coker has observed a ventral-canal-nucleus in $P$. coriaceus. ${ }^{4}$ In $P$. macrophyllus a well-defined ventral-canal-nucleus was not seen, but a safranin-staining mass present in the upper part of some archegonia may have been the disorganizing ventral-canal-nucleus. There is no evidence of this nucleus being cut off by a wall.

In $P$. coriaceus ${ }^{5}$ the neck consists of from two to twenty-five cells. Although such an extreme variation was not noticed in $P$. macrophyllus, yet the variation in number is certainly considerable in the mature archegonia, and as many as eighteen cells have been counted in the neck of one archegonium. ${ }^{6}$

Before fertilization the egg nucleus undoubtedly undergoes rapid increase in size. Unfortunately, measurements are not available for the young and old egg nucleus in the same species. In $P$. latifolius the diameter of the nucleus of the young archegonium is about $25 \mu$, while in

1 Lawson ('042), p. 427 .

4 Coker ('02), p. 98 . ${ }^{2}$ Young ('07), p. 87 .

3 Miyake ('11), p. I I.

6 The structure of the archegonium neck would thus appear to differ markedly from that of Phyllocladus and Dacrydium. See Young ('10) and Stiles ('11). 
P. macrophyllus the egg just before fertilization (P1. XLVIII, Fig. $3 \mathrm{I}$ ) is about $45 \mu$ or $50 \mu$ in diameter.

Before fertilization takes place the nuclei of the prothallus cells begin to divide, but the products of division are not cut off by cell-walls, and as the process may be and generally is repeated more than once, the prothallus cells in the old seeds may contain as many as eight nuclei. This is evidently a phenomenon of general occurrence in the genus, as it takes place in all species that have so far been examined, namely, $P$. coriaceus by Coker, and $P$.nagi, $P$. macrophyllus, $P$. elatus, and $P$. latifolius, by the writer.

The development of more than one megaspore in an ovule is a phenomenon that has been observed in several Coniferous genera $;^{1}$ it has been recorded for Podocarpus by Coker in $P$. coriaceus. ${ }^{2}$ In both $P$. latifolius and $P$. macrophyllus an example of this has been found among the writer's material; in the former case the prothalli were in a young stage before wall formation had commenced, but in the case observed in $P$. macrophyllus both prothalli had produced archegonia, and one contained a pro-embryo.

In Phyllocladus, ${ }^{3}$ Saxegothaea, ${ }^{4}$ Microcachrys, ${ }^{5}$ and Dacrydium laxifolium $^{6}$ a thick megaspore membrane of the usual type is developed, but in the two species of Podocarpus examined by Thomson, $P$. coriaceus and $P$. macrophyllus, subsp. maki ( $P$. Makoyi, P. chinensis, or $P$. sinensis), no trace of a megaspore coat could be found. From the species examined in the course of this work it is evident there is great variation in the genus as regards this structure. In $P$. macrophyllus and $P$. nagi the membrane is very poorly developed, and never appears to be more than I $\mu$ thick. Only an isolated late stage has been observed in the case of $P$. elatus, and here also the membrane was very poorly developed. $P$. latifolius, on the other hand, is in marked contrast to these species. At about the $3^{2-}$ nucleate stage of the prothallus the megaspore membrane is well under I $\mu$ thick, while by the time the neck-cells are cut off from the central cells of the archegonia the membrane forms a thick coat about $4.2 \mu$ thick. It thins out towards the apical part of the prothallus, and is not more than $2 \mu$ thick in the region of the archegonia. By the time the pro-embryos are developing the membrane becomes thinner, and is then about $2.5 \mu$ thick in the middle region of the prothallus.

\section{x. Male Gametophyte.}

\section{A. Early History (Structure of Pollen).}

The early history of the male gametophyte, from the microspore stage up to the time of shedding of the pollen, has been investigated in species of all genera of the Podocarpeae except Pherosphaera. The later history from

1 e. g. Sequoia (Lawson, '04'1 , p. 10); Callitris (Saxton, '10, p. 559).

${ }^{2}$ Coker ('02), p. 97 . 3 Young ('10), pp. 86, 88.

5 Thomson $\left(09^{2}\right), \mathrm{p} \cdot 349$.

6 Thomson $\left({ }^{\prime} 05^{1}\right)$.

* Norén ('08), p. I I 5 . 
the beginning of pollen-tube development up to fertilization has only been observed in two cases : in Podocarpus coriaceus ${ }^{1}$ and Phyllocladus sp. ${ }^{2}$

A most excellent general account of the early stages of development has already been published by Coulter and Chamberlain, ${ }^{3}$ and as the additional species examined by the writer behave similarly in this respect to those already observed, only a brief account of this part of the subject is necessary.

As regards gross structure, the pollen-grains of Saxegothaea ${ }^{4}$ are wingless; those of Microcachrys possess wings which are, however, small and variable in size and number, three being the most frequent number met with. In Phyllocladus, Dacrydium, and Podocarpus the wings are on the whole larger and are two in number, although three wings are found exceptionally in Podocarpus ferruginea, ${ }^{5}$ and normally in Podocarpus dacrydioides. ${ }^{6}$

The feature of the gametophyte which has attracted most attention is the comparatively large development of prothallial tissue, a feature first noticed by Thibout ${ }^{7}$ in Podocarpus polystachyus. In all the species so far investigated two prothallial cells are cut off successively, as in the Abietineae. In Saxegothaea ${ }^{8}$ the second prothallial cell always divides into two daughtercells, and the first often divides as well. This prothallial complex of three or four cells persists up to the time of pollination, which is as far as the development of the male gametophyte has been observed. An exactly similar condition probably obtains in Microcachrys. ${ }^{9}$ An essentially similar condition has been found in Dacrydium Bidwillii, where, as a rule, only the second prothallial cell divides, and in $D$. cupressinum and $D$. laxifolium, where generally both prothallial cells divide. ${ }^{10}$ A less active condition prevails in Phyllocladus, ${ }^{11}$ where usually neither cell divides, although the second occasionally does so.

In Podocarpus there is apparently a more variable condition. In $P$. coriaceus, Coker ${ }^{12}$ found that the primary prothallial cells might divide amitotically. Jeffrey and Chrysler ${ }^{13}$ found in $P$.polystachyus, $P$. ferrugineus, and $P$. dacrydioides that both the prothallial cells might undergo two successive divisions, making a total of eight prothallial cells. Burlingame ${ }^{14}$ recorded a similar condition in $P$. Totara, var. Hallii, but reported a great deal of variation in the number of prothallial cells produced, namely, from one to eight, six being the most usual number. Mr. Brooks and the writer have found that as many as eight prothallial cells may be produced in $P$. spimulosus. ${ }^{15}$ As many as eight prothallial cells are also produced in $P$. andinus.

1 Coker ('02), p. $94 . \quad{ }^{2}$ Young ('10), p. 82.

${ }^{4}$ Norén ('08), p. I05; Stiles ('08), p. 2 I 3.

6 Thibout ('96), Pl. XIV, Figs. Io and II.

8 Norén ('08), p. 106.

10 Young ('07), p. $19^{2}$.

${ }^{12}$ Coker ('02), p. $9^{2}$.

14 Burlingame ('08), p. I69.

${ }^{3}$ Coulter and Chamberlain ('10), p. 339.

5 Thomson $\left(' 09^{1}\right)$, p. 29.

7 l. c., Figs. 8 and 9.

9 Thomson $\left({ }^{\prime} 09^{1}\right)$, p. 28.

11 Young ('10), p. S2.

13 Jeffrey and Chrysler ('07).

15 Brooks and Stiles (10), p. 309. 
After the cutting off of the two primary prothallial cells, the antheridial cell divides into the tube-cell and the generative cell. The latter is cut off from the former in much the same way as the primary prothallial cells. This division is followed by the division of the generative cell into what may be called the stalk-cell and the body-cell, but the division in all the Podocarpeae is an anticlinal one, so that the products of division lie side by side. Jeffrey and Chrysler have described in Podocarpus ferrugineus and $P$. polystachyus ${ }^{1}$ an appearance as of a second derivative of the generative cell besides the so-called stalk-cell, and a similar appearance was noted by Mr. Brooks and the writer in P. spinulosus. ${ }^{2}$ Miss Young has suggested ${ }^{3}$ that this appearance is due to the partial encircling of the body-cell by the stalk-cell, and this may well be so in $P$. spimulosus.

In all the Podocarpeae the limiting membranes of the prothallial cells and stalk-cell break down, and the nuclei come to lie free in the general cytoplasm. Thus, at the time the grain is shed the body-cell is the only one surrounded by a definite membrane. In Podocarpus spinulosus it was observed that at this stage the tube-nucleus is the largest in the grain, and the same is true of $P$.andinus and $P$. latifolius. In no instance in $P$.andinus were more than eleven nuclei observed in one pollen-grain, so there is presumably no second derivative of the generative nucleus in this species.

\section{B. Later History (Development of Pollen-tube).}

The development of the gametophyte beyond the stage just described has been observed in very few cases. Miss Young ${ }^{4}$ has observed stages in Dacrydium laxifolium and $D$. intermedium in which the pollen-tubes have commenced to grow through the nucellus. Only in two cases, however, has the development been followed further, in Podocarpus coriaceus ${ }^{5}$ and in Phyllocladus sp. ${ }^{6} \quad$ These are the species in which the least development of prothallial tissue has so far been recorded, so that special interest attaches to the investigation of the later stages of the gametophyte in forms more typical of the order in respect of prothallial development. Observations have been made on the later history of the microgametophyte in Dacrydium cupressinum, Podocarpus macrophyllus, $P$. latifolius, and $P$. nagi. As in the case of the female gametophyte, it is to be regretted that the difficulties of collection of three of these species did not permit of the use of fixatives suitable for cytological work.

I. Dacrydium cupressinum. In this species it would appear that fertilization takes place a year after pollination. Ovules collected near Wellington, New Zealand, in July - that is, in the middle of the resting

1 Jeffrey and Chrysler ('07).

3 Young ('10), p. 83.

- Coker ('02), p. 94 .
2 Brooks and Stiles ('10), p. $3 \circ 9$.

4 Young ('07).

6 Young ('10), p. 84. 
period-all showed pollen-tubes that had penetrated a considerable way through the nucellus.

On germination of the pollen-grain the inner layer of the wall bursts through the outer and forms the pollen-tube. Miss Young ${ }^{1}$ has described the entry into the pollen-tube of the tube, stalk, and prothallial nuclei in $D$. intermedium, the body-cell remaining behind in the grain. The same thing takes place in the case of $D$. cupressinum. Although the tubes had penetrated a long way into the nucellus, in every case examined the bodycell remained behind in the grain (Pl. XLVIII, Fig. 25). In most cases the tube itself had grown straight down the nucellus and showed no sign of branching. Five or six nuclei were found in most of the tubes besides the nucleus of the body-cell. In the longer tubes, one nucleus, which occupied a position near the growing end of the tube, was much larger than the rest, and was probably the tube-nucleus. The remaining nuclei were indistinguishable from one another, and would be the stalk-nucleus and prothallial nuclei; there would thus be three or four of the latter. Four is the number found by Miss Young in the pollen-grain when ready for shedding, so, unlike Agathis, no further divisions occur among the prothallial nuclei after the shedding of the pollen. In one case a peculiar phenomenon was noticed. The growing nucellar tissue had apparently pressed against the pollen-tube so as to pinch off as it were the upper part attached to the pollen-grain, and thus containing the body-cell, from the lower part containing the tube-nucleus. In this case the tube-nucleus had presumably divided, for two large nuclei were found together near the tip of the tube in the place generally occupied by the solitary tube-nucleus(Pl. XLVIII, Fig. 26). Either nucleus of the pair was as large as an ordinary tube nucleus. This is, as far as I am aware, the only case so far recorded of the division of the tube-nucleus. In the pollen-grain and in the upper part of the tube starch grains are very abundant. Unfortunately, later stages of gametophytic development have not been available, so no further information can be given in regard to this genus in this connexion. ${ }^{2}$

II. Eupodocarpus. Material of two species of this subgenus has been used in this investigation; these species are Podocarpus latifolius and $P$. macrophyllus. Only early stages of the former species were available, and the following description applies almost entirely to $P$. macrophyllus.

The pollen-grains alight in a slightly concave receptacle formed by the apex of the nucellus. It was observed that in one case in $P$. macrophyllus the tube from a pollen-grain, that had come to rest at one extremity of the nucellus, grew along the top of the latter until it reached the middle of the concave portion. In all cases observed the pollen-tubes, after entering the nucellus, grow straight down until they reach the surface of the female

1 Young ('07), p. 193 .

${ }^{2}$ In Dacrydium Colensoi the body-cell nucleus gives rise to two unequal male nuclei (Stiles, '11). 
prothallus. Here they expand in a remarkable manner so as to cover almost completely the upper region of the prothallus. From this expanded portion branches grow down in all directions (P1. XLVIII, Fig. 27). The pollen-tube wall is rather thick, about twice as thick in fact as the megaspore membrane. At this stage wall formation was taking place in the female prothallus.

The body-cell is a conspicuous object, consisting of a dense mass of cytoplasm containing a large nucleus. As described for $P$. coriaceus, ${ }^{1}$ and as is also the case in P.nagi, the nucleolus is the only part which shows any marked tendency to take the safranin stain. The nucleus at this stage was always excentrically placed in the cytoplasm. The cell itself is not necessarily spherical ; in one case it was conical, with the nucleus at the base of the cone, and giving the impression of a moving cell with the nucleus in front.

Small nuclei are found in the tube-in one case they numbered fivewhile a mass in the pollen-grain staining densely with safranin suggests that some nuclei never leave the grain and disorganize there. No distinction could be made out between the prothallial, stalk-, and tube-nuclei; all the small nuclei in the tube appeared similar. Sometimes two or three of these small nuclei were clustered near the body-cell, as was found in the observed cases of $P$. nagi; but this was not always the case, for sometimes the body-cell was quite by itself. At this stage the body-cell is of considerable size.

No further change is noticeable in the gametophyte until the division of the body-cell. This evidently took place about July 20 , for in one ovule collected on this date, of four pollen-tubes which had penetrated the nucellus, one contained an undivided body-cell, while in each of the other three the body-cell had undergone division. Here, as described for $P$. coriaceus, ${ }^{2}$ the division of the body-cell results in the formation of two unequal male nuclei (Pl. XLVIII, Figs. 28, 29, 3I). The functional one is found embedded in the middle of the body-cell cytoplasm; the other moves, apparently in a very short space of time, to the side of the cytoplasm, and often that side remote from the female prothallus. The functional male nucleus takes deeply the safranin or haematoxylin stain, being in this respect in marked contrast to the body-cell nucleus. The non-functional male nucleus gradually undergoes degeneration. Several ovules showed very prettily the male nuclei just outside an archegonium (Fig. 3I). The functional male is still embedded in the middle of the body-cell cytoplasm, while the degenerate male nucleus is still obvious. In all cases observed at this stage it was remarkable that small nuclei, sometimes as many as six in number, were always observed clustered against the body-cell (Pl. XLVIII, Figs. 29 and 30). Whether they are the original prothallial, stalk-, and tube-nuclei, or whether some of these degenerate, while others in the neighbourhood survive and 
divide, is a question that could not be definitely decided, but the facts suggest the former alternative.

III. Podocarpus nagi. Owing to the exceedingly small quantity of material available of this species the observations are of a very meagre description. The youngest material examined was collected by Dr. Stopes at Tokyo on July i 3. The ovules were abundantly supplied with pollentubes, as many as eight having penetrated through one nucellus. Between this and the female prothallus they formed so complicated a tangle that it was found impossible to distinguish between the various tubes in a series of sections. Indeed, the number of pollen-tubes could only be found by counting the number of body-cells contained in them, so in the unlikely event of there being more than one body-cell in one tube the number of tubes would be correspondingly lower. Under these circumstances it was found difficult to estimate the number of prothallial nuclei in one tube ; in one case, however, eight small nuclei were found near a body-cell in one tube, while in several other cases at least six nuclei were present. Allowing for the presence of the stalk- and tube-nuclei, which by this time are indistinguishable from the prothallial nuclei, there may be at least as many as six prothallial nuclei in the pollen-tube at this stage.

The further course of events seems to follow closely that in P. macrophyllus, two male nuclei being produced, one of which comes to lie centrally in the body-cell cytoplasm, while the other is non-functional, and degenerates on the outside of the body-cell cytoplasm.

\section{xi. Embryology.}

The embryology of Podocarpus coriaceus has been described by Coker, ${ }^{1}$ and that of $P$. macrophyllus is similar. The fusion-nucleus sinks to the basal part of the archegonium and there undergoes successive divisions, so that at least sixteen free nuclei are formed before wall formation takes place. While these divisions are proceeding the basal part of the archegonium wall swells up and becomes conspicuous owing to its power of staining with safranin. This is shown in Pl. XLVIII, Fig. 32, which is a drawing of a section through two archegonia, in one of which the pro-embryo is undergoing the third division, while the other is in the eight-nucleate stage. (All the nuclei are of course not shown in a single section.) The stage directly after wall formation was not observed, but no doubt the same tiers of cells are formed as in $P$. coriaceus.

The embryo consists of a single cell for some time after the suspensors have commenced to elongate. Coker has observed the formation of several embryos from a single egg in $P$. coriaceus; there was no case of this seen in $P$. macrophyllis. The embryo later produces a large cylindrical mass

\footnotetext{
1 Coker ('02), p. 100.
} 
of tissue which ultimately differentiates into the radicle and the two cotyledons (Pl. XLVI, Figs. I2-I4). As the latter in the course of their growth destroy the prothallus cells a plug of prothallus tissue is left between them and presents a striking appearance (Pl. XLVI, Fig. I4).

In the mature seed the procambial strands are already obvious, and it is evident that the cotyledons will each contain two vascular bundles at some distance from one another (Pl. XLVI, Fig. I3).

\section{xii. Seedling Structure.}

As far as I am aware the only recorded observations on seedling structure of the Podocarpeae are the fragmentary ones of Geyler ${ }^{1}$ and Van Tieghem ${ }^{2}$ on Phyllocladus, and those of Hill and de Fraine ${ }^{3}$ on a single species of Podocarpus, $P$. chinensis ( $P$. macrophyllus, subsp. maki). Further observations on this part of the subject are therefore needed; in this work, however, no material of seedlings was available.

From the observations referred to it appears that in $P$. macrophyllus, subsp. maki there are two cotyledons, each traversed by a pair of vascular bundles endarch and collateral in nature. Transfusion tissue is developed laterally. The primary root is diarch, each pole of the primary xylem being continuous with the fused pair of xylem-strands of one cotyledon. The same arrangement probably obtains in Phyllocladus, but of other genera we know nothing.

xiii. Geographical Distribution.

The Podocarpeae have a very interesting distribution. Pherosphaera has two species, one of which is found only in the mountains of New South Wales, while the other occurs exclusively on the mountains of Tasmania. The genus Microcachrys has the same very limited range as the latter species, while Saxegothaea occurs only on the Chilian Andes. Dacrydium is essentially an island type, being almost limited to the islands of the Malay and Australasian region; one species, however (D. Fonkii), occurs in the Andes of Chili. The distribution of Phyllocladus is similar to that of Dacrydium, but is more restricted in its range. In marked contrast to the other genera is Podocarpus. This must be regarded as the dominant Conifer in the Southern Hemisphere, as it occurs in South America, the West Indian Islands, South and Central Africa, Australia, Tasmania, New Zealand, and the Australasian and Malay Archipelagoes. It stretches into the Northern Hemisphere in China, Japan, the Malay Peninsula, Burma, and India. On the whole it may be said that Podocarpus occupies the place in the Southern Hemisphere that is occupied in the Northern Hemisphere by Pinus. These two genera must be regarded, both from the point of view of numbers of species and of wide geographical distribution, as the successful Conifers of the present day.

\footnotetext{
1 Geyler, T. H. ('81).

2 Van Tieghem ('70).

${ }^{3}$ Hill, T. G., and de Fraine, E. ('08), p. 694.

$\mathrm{K} \mathrm{k}$
} 
Perhaps the most noticeable feature of the distribution of the living Podocarpeae is its similarity to that of the Araucarieae. ${ }^{1}$ This has been regarded ${ }^{2}$ as of significance in regard to the view of the near relationship of these two orders. We know, however, so little of the causes of presentday geographical distribution that it is doubtful what the significance of this similarity of geographical distribution is. The Araucarieae were probably abundant in the Northern Hemisphere in past times, ${ }^{3}$ but on the other hand little is known of the past distribution of the Podocarpeae. It has been suggested that the Podocarpeae may have been a southern offshoot of the Araucarieae, ${ }^{4}$ but there does not seem to be evidence either in support of, or against this view, from the facts of distribution.

\section{xiv. Fossil Podocarpeae.}

Very little is known as to the existence of Podocarpeae in past times, although many plant remains have been referred to this order. These fossils fall into three groups: impressions of leaves and branches, petrified wood, and impressions of cones, cone scales, and seeds.

\section{Impressions of Leaves and Branches.}

A good many impressions of leaves and branches have been referred to Podocarpus or allied genera; the more noteworthy of these records are as follows :

Mesozoic. Under the generic name of Protophyllocladus Berry has separated the mid and late Cretaceous species formerly included in the genus Thinnfeldia. ${ }^{5}$ A relationship to the recent Phyllocladus cannot, however, be regarded as by any means proved, for the characters on which Berry relies for identification, namely size and shape, petiolation, and venation, do not even show that the impressions are those of phylloclades. Indeed, Berry himself speaks of them as leaves, and mentions that Knowlton formerly pointed out the resemblance of Protophyllocladus lanceolatus, (Knowlton) Berry, to various species of Podocarpus.

From the Potomac or Younger Mesozoic Flora of the United States Fontaine has described fourteen species of Nageiopsis. ${ }^{6}$ The leaves of this genus are parallel-veined, and show a general resemblance to the leaves of Podocarpus $\S$ Nageia. In a revision of the genus Nageiopsis, Berry $^{7}$ has reduced Fontaine's fourteen species to three. Other species have been referred to the same genus by Seward, one from the Wealden 8 and another from the Inferior Oolite of Yorkshire. ${ }^{9}$ However, the parallel

\footnotetext{
1 See Seward and Ford ('06), p. 308, Map.

3 Seward and Ford, 1. c.

5 Berry ('03), p. 439.

7 Berry ('10), p. 189.

9 Seward ('00), p. 288.
}

2 Young ('10), p. 93.

4 Coulter and Chamberlain, ('10), p. 35I.

6 Fontaine ('89), p. 195, et seq.

8 Seward ('95), p. 21 I. 
venation of the leaves, the persistence of the latter, and the non-convergence to a union of the veins at the tip of the leaf are scarcely sufficient evidence of a Nageian affinity. Indeed, Nageiopsis anglica, the Yorkshire specimen, is regarded by both Seward and Berry as possibly of Araucarian affinity.

A second genus of Fontaine's ${ }^{1}$ from the Potomac is Phyllocladopsis. From Fontaine's figure, however, there is little evidence of Phyllocladean affinity.

From the Cretaceous of New Zealand Ettingshausen has described and figured various leaves which he refers to the genera Podocarpium and Dacrydinium. ${ }^{2}$ The evidence of a Podocarpean affinity is however slight, as the leaves do not differ in any essential feature from those of any Conifer with a Taxus-like leaf. The impression named by the same writer Ginkgocladus Novae-Zeelandiae ${ }^{3}$ is interesting, as it is apparently part of a phylloclade which might quite well have belonged to a Phyllocladus. As in other cases, however, the evidence is not definite.

Tertiary. Leaves from Tertiary beds referred to Podocarpus and Dacrydium have been described by Gardner from England, ${ }^{4}$ and by Ettingshausen from Australia ${ }^{5}$ and New Zealand. ${ }^{6}$ These cases are specially mentioned, as fruits in each of these three instances were found occurring with the leaves. As regards the latter it can only be said that although they might be Podocarpean leaves, the evidence is not sufficient to prove they might not have belonged to some other Coniferous genus. Similarly, the impression named Phyllocladus asplenioides by Ettingshausen ${ }^{7}$ appears to resemble a Phyllocladus, but this does not seem to be sufficient indication of relationship.

If all these references of leaf impressions are correct it means that forms near to the modern Phyllocladus, Dacrydium, and Podocarpus were in existence in Mesozoic times in Britain, in North America, and in New Zealand. But it is well known how unsatisfactory are references based on leaf impressions, and this is especially so in the case of the Coniferae, where throughout the group there is such uniformity of type as regards leaf structure. Even references of recent plants based on leaf characters have been very incorrect; thus the plant named by Sir W. J. Hooker Podocarpus? Diffenbachii ${ }^{8}$ ultimately turned out to be a species of Veronica. As Professor Seward has said, "Tempted by a resemblance in the form of the leaves, one is often inclined to assume a relationship with existing Conifers which rests on wholly insufficient evidence.' ${ }^{9}$

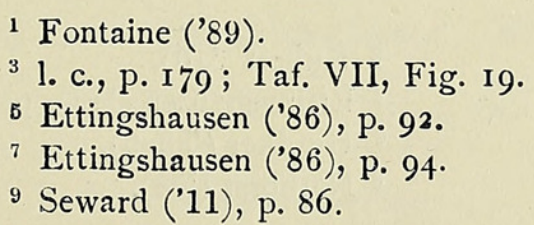

2 Ettingshausen ('87), p. I 77.

4 Gardner (' $83-6$ ), p. $4^{8}$.

6 Ettingshausen ('87), p. I 56.

${ }^{8}$ Hooker, Sir W. J. ('43), No. 547. 


\section{Petrified Wood.}

Gothan ${ }^{1}$ has recently described several examples of petrified wood which he ascribes to the genera Podocarpoxylon and Phyllocladoxylon on account of the structure of the wood, special stress being laid on the medullary ray pitting. Another species has also been described by Kubart under the name of Podocarpoxylon Schwendae. ${ }^{2}$ These woods certainly appear to resemble existing species of Podocarpeae as far as the structure of the wood is concerned; the difficulty lies in determining how far the structure of the Podocarpean woods examined by Gothan can be regarded as characteristic of the Podocarpeae, recent and fossil. A similar wood structure is known to exist in forms not very nearly related, and it is of course possible that this may be the case here. At present, therefore, it seems best not to regard as proved the references of petrified wood to a Podocarpean affinity.

\section{Impressions of Cones, Cone Scales, and Seeds.}

Ettingshausen has described an impression from the Cretaceous of New Zealand as a fruit of Podocarpium Ungeri, ${ }^{3}$ while from the Tertiary of Australia ${ }^{4}$ and New Zealand ${ }^{5}$ fruits referred to species of Podocarpus have been described by the same writer. None of the figures of these species can, however, be regarded as at all convincing of Podocarpean affinity.

Two fruits referred to Podocarpus have been figured by Gardner as occurring in the British Eocene Flora. ${ }^{6}$ These figures certainly show a resemblance to Podocarpus seeds, but unfortunately not much detail is evident to make certain their reference.

Of great interest are certain fossils that have been described by Professor Nathorst. The genus Carpolithes, ${ }^{7}$ as Nathorst says, shows much resemblance to the recent form Podocarpus spicatus in that a number of seeds are arranged on a spike.

Two fructifications of Rhaetic age recently described by Professor Nathorst are suggested by him as having possibly a Podocarpean affinity. ${ }^{8}$ They are Stachyotaxus and Palissya. There seems to be good evidence of an epimatium in the former genus at any rate, although it does not seem to be so asymmetrical as the typical Podocarpean epimatium. In any case these genera differ exceedingly from any recent Podocarpean fructification, for Stachyotaxus had two ovules to the cone scale, while Palissya had as many as Io or $\mathrm{I} 2$ to the scale, and it has been shown

1 Gothan ('05), ('07), ('08).

3 Ettingshausen ('87), p. I77.

5 Ettingshausen ('87), pp. I 56, $157^{\circ}$

7 Nathorst ('78), p. 27 , Taf. XV, Figs. I 4, I 5 .
2 Kubart ('10).

4 Ettingshausen ('86), p. 92.

6 Gardner ('83-6).

8 Nathorst ('08). 
that the most characteristic feature of the Podocarpeae is the single ovule borne medianly in relation to the cone scale. It may be of course that we have in these fossils connecting links between the Podocarpeae and other orders, but at the present time such considerations are at best only conjectures.

A very interesting petrified cone has been described by Hollick and Jeffrey from the Cretaceous of Kreischerville under the name of Strobilites microsporophorus. ${ }^{1}$ The cones were small and slender, while each sporophyll bore two sporangia containing microspores, each with two wings. The resemblance to a Podocarpean male cone is obvious, while Hollick and Jeffrey's figures are very reminiscent of the structure of the microsporophyll of Podocarpus andinus. The authors regard it as belonging to a 'generalized araucarineous type, nearer in the structure of its male sporophylls to the Abietineae, than are any of the existing Araucarineae '. ${ }^{2}$ Similarly, it is also nearer to the Podocarpeae than are any of the existing Araucarineae, and to the writer it seems quite possible that it combines features of all three orders, and is in this sense a synthetic type.

Prominence has been given in the past to the similarity of the fossil cone Walchia filiciformis ${ }^{3}$ to the Araucarieae. ${ }^{4}$ This may serve to emphasize the connexion between the Araucarieae and Podocarpeae, for the arguments that are used in favour of the relationship of Walchia with the Araucarieae may be used equally well in support of a relationship between Walchia and Saxegothaea.

Thus the consideration of the fossils referred to the Podocarpeae afford little or no evidence either as to the course of phylogeny in the order, or as regards past geographical distribution, and this is due to the unsatisfactory nature of the plant remains referred to an affinity with the order.

This absence of evidence, however, must not be regarded as equivalent to evidence of absence in past times. The present distribution of the Podocarpeae is almost entirely a Southern one, while it is chiefly the rocks in the Northern Hemisphere that have been explored for fossil plant remains. As Burlingame remarks of the Podocarpeae, "We know but little of the plant remains of those parts of the world in which these remains would be most likely to be found. ${ }^{5}$

\section{xv. Inter-Relationships of the Genera and Species.}

That the six genera included in the Podocarpeae in this paper form a natural group cannot, I think, be doubted when the sum of their characters is taken into consideration. The structure of the wood of the stem, the

1 Hollick and Jeffrey ('09), p. 66.

3 Zeiller ('92), p. 99, Pl. XV.

5 Burlingame ('08), p. I 5 .
2 1. c., p. 68.

4 Seward and Ford ('06), p. 373. 
anatomy of the leaves, the remarkable uniformity of structure exhibited by the male cones, the constant relationship of a single medianly placed ovule to a megasporophyll, the simple character of the latter, and the development of prothallial tissue in the male gametophyte, ${ }^{1}$ all give evidence of the natural relationship of the genera here included in the Podocarpeae. That we must look for the nearest approach to the common ancestor of them all among the types with the megasporophylls aggregated into cones seems obvious. Apart from the fact that the fructifications of Dacrydium and Podocarpus give evidence of their reduction from more perfect cones, ${ }^{2}$ it is the genera Pherosphaera, Microcachrys, and Saxegothaea which have a very limited distribution, and in every group of vascular plants it is as a rule among such genera of restricted range that we expect to find the more primitive members of the group. Many species and wide geographical range are the indications of a successful genus, and success in the struggle for existence means the evolution of characters capable of struggling with modern conditions. For this reason, although it is possible, yet it is extremely improbable that a genus with a wide range and many species will approach so nearly the primitive type of its order as the genera with few species and restricted range, which are probably old types making their last stand against newer conditions.

Again, it is in the structure of these species with female cones that we find most indications of primitiveness. The presence of a certain amount of centripetal wood in the axes of both the male and female cones of Saxegothaea, together with the gradual transition from foliage leaves to sporophylls in the case of the female cones, support this view.

The evidence derived from the development of ovulate structures affords fairly conclusive proof that the ovule was originally borne erect in the axil of the sporophyll, for it probably arises in this position in all the genera, although its position may be altered by later growth (Text-fig. 8). It was probably surrounded by a single integument, as it remains presumably throughout the whole course of its development in Pherosphaera.

The male cones are so uniform throughout this order that they afford little evidence as to the inter-relationships of the genera. The transverse dehiscence of the sporangia of Saxegothaea is probably more primitive than the oblique dehiscence in most of the species of Podocarpus. The wood of the stem is remarkably uniform throughout the order, but suggests that an arrangement of bordered pits in contact is primitive in the order.

From the account already given of the structure of the leaves of the Podocarpeae, ${ }^{3}$ it is evident that, with the exception of Nageia, all the leaves examined are modifications of one type. The central type is the leaf of Saxegothaea or Podocarpus andinus. There is a single vascular bundle with well-marked transfusion tissue developed right and left of the xylem, and

\footnotetext{
1 Pherosphaera is still unknown in respect of the male gametophyte.

${ }^{2}$ Brooks and Stiles ('10), p. 314. ${ }^{3}$ p. 453.
} 

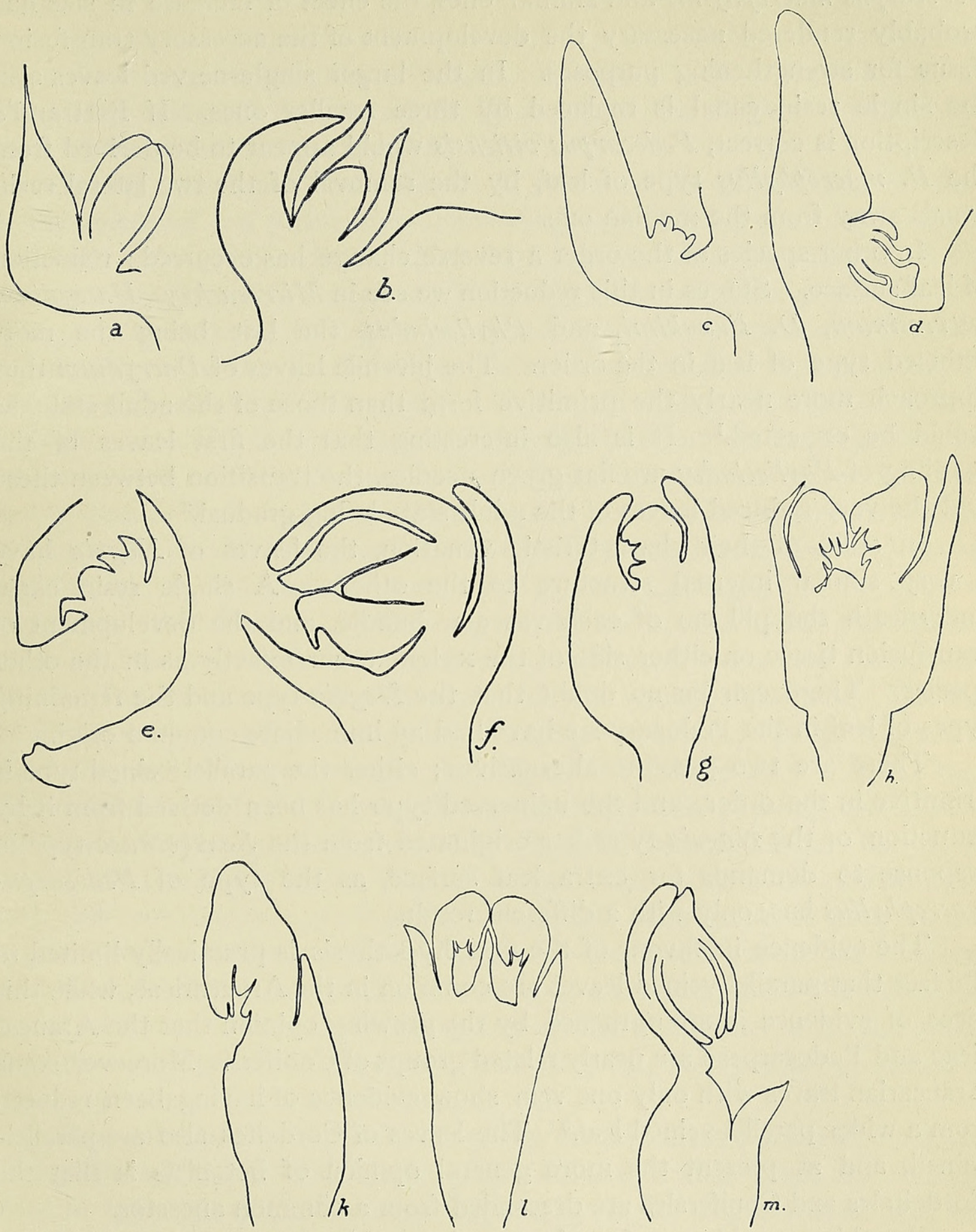

TEXT-FIG. 8. Diagrammatic representation of megasporophylls to show the relation of ovule and sporophyll throughout the Podocarpeae. a, Pherosphaera (after Pilger, '03); b, Phyllocladus (young stage, after Robertson, '06); c, Saxegothaea (young stage, after Norén, '08); d, Saxegothaea (older stage, after Norén, '08); e, Microcachrys (young stage); $f$, Dacrydium cupressinum (young stage); $g$, Podocarpus latifolius (young stage); $h, k$, Podocarpus latifolius (older stages); $l$, Podocarpus spinulosus; m, Dacrycarpus (after Pilger, '03). 
with a single functional resin canal on the under side. In the leaves of Podocarpus macrophyllus and similar ones, the effect of increase in size has probably rendered necessary the development of the accessory transfusion tissue for strengthening purposes. In the larger single-nerved leaves also the single resin canal is replaced by three smaller ones. If Bertrand's description is correct, Podocarpus vitiensis would appear to be derived from the $P$. macrophyllus type of leaf, by the removal of the two lateral resin canals away from the median one.

In other species of the order a reverse change has occurred : reduction of leaf surface. Stages in this reduction we see in Microcachrys, Dacrydium cupressinum, D. Franklini, and Phyllocladus, the last being the most reduced type of leaf in the order. The juvenile leaves of Dacrydium thus approach more nearly the primitive form than those of the adult state, as would be expected. ${ }^{1}$ It is also interesting that the first leaves of the seedling of Phyliocladus are flat green needles, the transition between these and the very reduced leaves of the adult state being gradual. ${ }^{2}$

In spite of their characteristic venation, the leaves of Nageia have a very similar internal structure to the others. A single resin canal underneath the phloem of each vascular bundle, and the development of transfusion tissue on either side of the xylem, occur exactly as in the other species. There can be no doubt that the Nageia type and the remaining types of leaf in the Podocarpeae have had an immediate common origin.

There are two possible alternatives; either the parallel-veined type is primitive in the order, and the uninerved type has been derived from it by reduction, or the Nageia type has originated from the Saxegothaea type in response to demands for extra leaf surface, as the type of Podocarpus macrophyllus has, only with a different result.

The evidence in favour of the first hypothesis is practically limited to the fact that parallel-veined leaves are common in the Araucarieae, while this piece of evidence is strengthened by the growing opinion that the Araucarieae and Podocarpeae are nearly related groups of Conifers. Moreover, some Araucarian leaves with only one vein show evidence of having been reduced from a wider parallel-veined leaf. ${ }^{3}$ The leaves of Cordaites also are parallelveined, and at present the more general opinion of botanists is that the Cordaitales and Coniferales are descended from a common ancestor.

But this resemblance of the leaves of Agathis to those of Nageia is only a superficial one. The internal structure of the leaves of Agathis is quite different from that of Nageia, especially as regards the distribution of the

${ }^{1}$ Cf. Goebel ('00, p. 154), who says with regard to the leaves of the Cupressineae, which in external characters closely resemble those of Dacrydium, 'the juvenile forms of these plants must undoubtedly be regarded as more primitive.'

2 Geyler ('81), p. 209 ; Coulter and Chamberlain ('10), p. 227 , Fig. $256, e, f$.

3 Seward and Ford ('06), p. $35^{\circ}$. 
canals. In Agathis these alternate with the vascular bundles, whereas in Nageia, as has been already observed, a single resin canal is present under each vascular bundle, and from the constancy of this character throughout the order it seems reasonable to attach importance to it. There is thus no convincing evidence that within the Podocarpeae the single-veined leaf has been derived from the many-veined one.

On the other hand, the evidence in favour of the greater primitiveness of the uninerved leaf seems more convincing. In the first place, with regard to leaves within the order, we find single-nerved leaves occurring in all the genera, while plurinerved leaves are found in one section of one genus only, and that genus the one which on general grounds must be admitted to be the least primitive in the order. In the second place, leaves of a closely similar structure are found in all other orders of Coniferae. In Araucaria Rulei ${ }^{\mathbf{1}}$ there is a single resin canal beneath the single vascular bundle as in the Podocarpeae, and, moreover, of all the Araucarieae it is this species which approaches most nearly Saxegothaea, not only in this respect, but also in the structure of the microsporangium, ${ }^{2}$ in the gradual transition between leaves and megasporophylls, ${ }^{3}$ and in the vascular anatomy of the megasporophyll. ${ }^{4}$ It is also of significance that Seward and Ford regard the leaf of $A$. Rulei as constituting in some measure a link between the two sections of the genus Araucaria. ${ }^{5}$ In the Taxeae also a leaf with a very similar structure prevails. The leaf of Taxus scarcely differs from that of Saxegothaea except in the absence of the resin canal from the former. Among the Abietineae the leaves of Tsuga Mertensiana and T. Pattoniana closely resemble those of Saxegothaea, while the leaves of other species may well be derivable from this type. Similarly, among the remaining orders, Taxodieae and Cupressineae, leaves with a not very different structure are found. These facts seem to me to point to this type of leaf as not only primitive in the Podocarpeae, but in the Coniferae as a whole. ${ }^{6}$ It is of course possible here, as elsewhere, to invoke reduction, but it seems an extraordinary thing if in all the Coniferous phyla the reduction from the primitive type has been so great, and yet has produced so nearly the same result in each case.

From these considerations it seems to the writer probable that the Saxegothaea type of leaf is the primitive one in this order, and that the Nageia type has probably been derived from the single-veined leaf, not merely during the course of phylogeny of the Podocarpeae, but during that of the genus Podocarpus itself.

The primitive Podocarpean plant can then be pictured as a tree, bearing probably spirally arranged leaves of a Yew- or Saxegothaea-like

\footnotetext{
1 Seward and Ford ('06), p. $35^{\circ}$.

2 Stiles ('08), p. 2 I 2.

${ }^{3}$ Seward and Ford ('06), p. $3^{6} \mathrm{I}$; Stiles ('08), p. 2 I 3.

4 Stiles ('08), p. 217.

5 Seward and Ford ('06), p. 35 I.

${ }^{6}$ Compare the remarks of Coulter and Chamberlain ('10), p. 225.
} 
appearance, and with its reproductive shoots bearing male and female cones, with the sporophylls spirally arranged. On the upper parts of the reproductive shoots there was a gradual transition between foliage leaves and sporophylls. Each microsporophyll bore two sporangia, while each megasporophyll bore in its axil a single erect ovule surrounded by a single integument.

From this primitive type we have had two main lines of development. In Pherosphaera there has been reduction in the size of the leaves and in the number of sporophylls in the cone; the megasporangium has, however, retained its primitive character. In Phyllocladus the reduction has proceeded still further, and there has occurred the special development of stems into phylloclades, physiologically to replace the leaves, here reduced to small insignificant scales. The ovule has also been clothed by a second integument completely surrounding the inner. The prothallial tissue in the male gametophyte consists of two or occasionally three cells; while in the small number of archegonia in the female gametophyte we perhaps have another reduction phenomenon. Owing to our absolute ignorance of the gametophytes of Pherosphaera, it is impossible to say whether in this respect Phyllocladus is further reduced than its otherwise more primitive relation.

Along the other line of descent we have intercalary growth taking place at the base of the megasporophyll, resulting in the removal of the ovule from the cone axis, and in many cases causing also its greater or less inversion. Probably correlated with this is the development of the incomplete outer integument or epimatium, for this is not present in any other phylum of Conifers, nor in the other Podocarpean line of descent. Whether this epimatium is an outgrowth of ovular or sporophyll tissue, it is at present impossible to say. The evidence of development in Saxegothaea and Microcachrys suggests the former, while a somewhat older state of Dacrydium cupressinum suggests the latter. The most primitive genus of this phylum is Saxegothaea, where the cone is still well developed. This is a somewhat smaller structure in Microcachrys, but is still a compact cone. The latter genus has also suffered reduction in its leaves and in the suppression of resin canals in the stem, though these are still present in the leaves and megasporophylls.

In Dacrydium Franklini the megasporangiate strobilus consists of about eight megasporophylls separated by appreciable internodes. The ovule is partially inverted, and the incomplete outer integument or epimatium is present, as in Saxegothaea and Microcachrys. As in the latter genus, resin canals are absent from the stem, but are present in the leaves and megasporophylls; in fact the internal structure of this plant, especially as regards the megasporophyll, is remarkably like Microcachrys. Curiously enough, both are limited in their distribution to Tasmania, though one is a small 
straggling mountain shrub, while the other is one of the tallest of forest trees.

In other species of Dacrydium, such as D. cupressimum, the female fructification contains but a single sporophyll, and so is reduced to the extreme limit. Occasionally, two fertile sporophylls may be borne on one 'strobilus'. The ovule has rather the appearance of being borne on the epimatium, but whether this is due to an outgrowth of the scale below the epimatium, or to intercalary growth of the basal part of the epimatium, cannot at present be said. In any case it is a new development not found in the more primitive members of the order or genus. The complicated structure of the inner integument is probably also a new development. The stems here contain resin canals as well as the leaves.

So far all the genera to which reference has been made in this section have the nucellus, integument, and epimatium free from one another, at least for a good part of their length. In the remaining genus, Podocarpus, the integument and epimatium are only free from one another for a very short distance in the neighbourhood of the micropyle. In the section Eupodocarpus the nucellus is free from the integument, at least in the species I have had an opportunity of examining, for about half its length. The characteristics of this line of evolution are fusion of parts and reduction of the female strobilus.

The two species, $P$. andinus and $P$. spicatus, in which the megasporangiate strobilus consists of about eight sporophylls on an elongated axis, are presumably to be considered the most primitive, reduction of the strobilus having proceeded to a less degree than in any other species. It is worthy of note also that the leaves are of the Saxbgothaea type, at any rate in $P$. andinus, while their external appearance suggests a similar structure in the case of $P$. spicatus.

In the section Eupodocarpus the fructification is reduced to three pairs of decussately arranged scales, of which the two upper pairs fuse to form the receptacle. Usually only one or two sporophylls are fertile. In the section Nageia the fructification is similarly reduced, while the peculiar venation indicates this section as a distinct offshoot of the pre-Eupodocarpus stock. Microcarpus with its single species would appear to be a reduced type on the Nageia line of descent. Finally, Dacrycarpus would appear to be the most specialized of them all as far as fusion of parts goes, for the megasporophyll is involved in the fusion. On the other hand, whereas in Eupodocarpus, and still more in Nageia, there is a tendency towards increased leaf surface, in Dacrycarpus, and also in Microcarpus, there is a reduction in this respect.

The suggested scheme indicating the inter-relationships of the genera and some of the species of the Podocarpeae is therefore as follows: ${ }^{1}$

\footnotetext{
${ }^{1}$ In this scheme genera and species shown above the oblique broken line exhibit fusion of parts in the ovulate structures; while those to the right of the vertical broken line have undergone reduction in their leaves.
} 


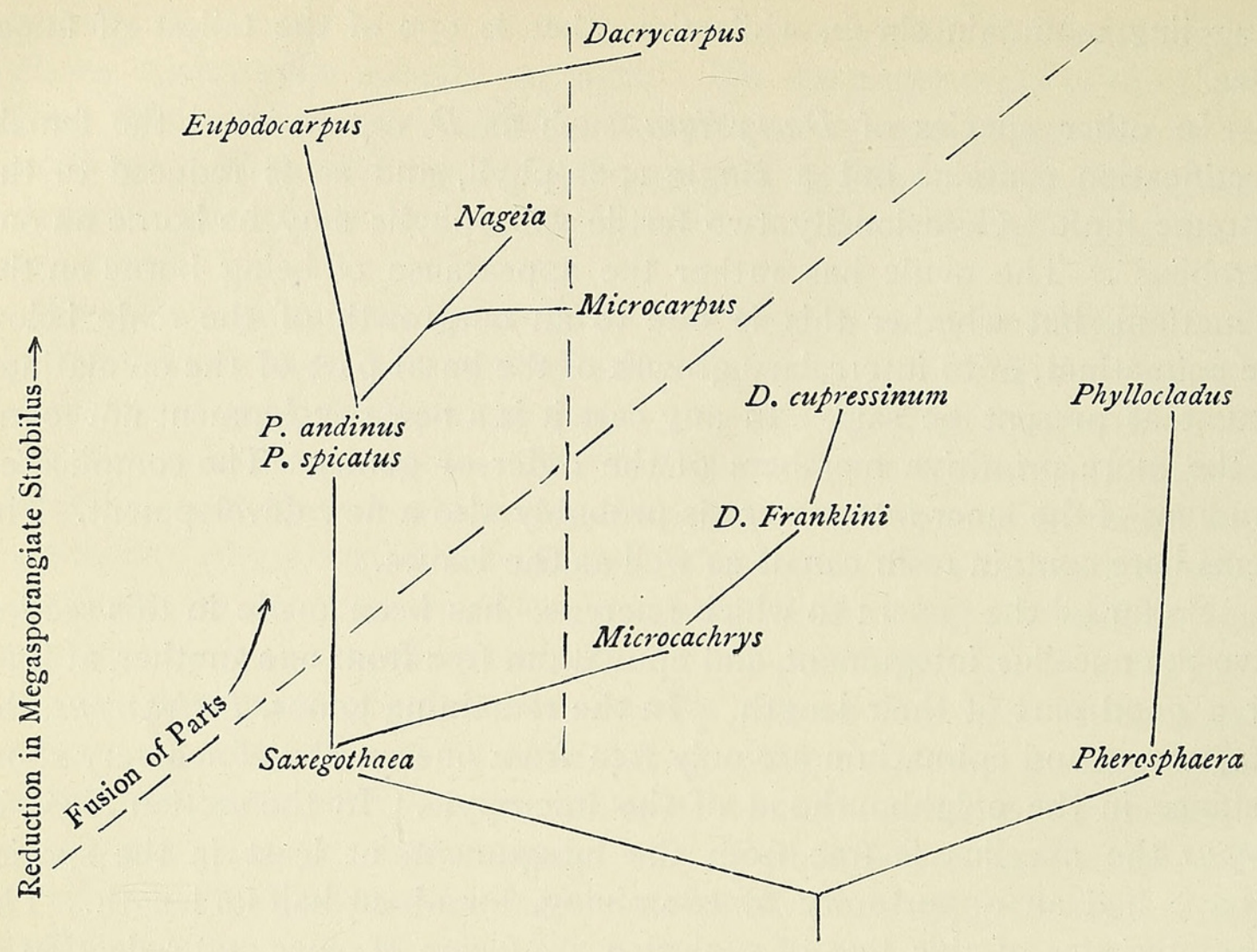

\section{xvi. Relations of the Podocarpeae to other Coniferae; PHYLOGENY.}

The question of the inter-relationships of the various phyla within the Coniferae is one on which very diverse opinions are held. The following quotation from the New Edition of Professors Coulter and Chamberlain's 'Morphology of Gymnosperms' shows how various are the views held with regard to the natural position of the Taxaceae (Taxeae and Podocarpeae). ' They have been called the oldest living conifers and the most recent ; they have been connected with Ginkgo through Cephalotaxus and with Cordaites on account of the structure of the ovuliferous shoot of Taxus; and the podocarps have been related to the araucarians through Dacrydium and Saxegothaea.' 1

During the last few years the opinion has been rapidly gaining ground that the Podocarpeae and the Araucarieae are directly descended from a common ancestor, the connecting link between the two orders being found in Saxegothaea. The first suggestion of this connexion really dates from as far back as Lindley, who actually classed Saxegothaea as one of the Pinaceae on account of its similarity to Agathis. ${ }^{2}$ Of late years the first suggestion of a revival of this view appears as a result of Miss Young's work on the male gametophyte of Dacrydium; this writer being struck with the development of prothallial tissue in the Podocarpeae, Araucarieae,

1 Coulter and Chamberlain ('10), p. 350.

2 Lindley ('53), p. $229 a$. 
and Abietineae, suggested in cautious terms the possibility of a common ancestry for the three orders. ${ }^{1}$ The investigation of Saxegothaea enabled a more definite statement to be made, so that Dr. Norén and the present writer in 1908 put forward independently the view that the two orders Podocarpeae and Araucarieae are related through Saxegothaea. Mr. Thomson and M. Tison, also working independently on Saxegothaea, have reached a similar conclusion. As the resemblance between Saxegothaea and the Araucarieae is not confined to a single character, but extends to the external features of the female cones, the internal structure of the cone scales, the male gametophyte, and, though not to so marked an extent, to the structure of the microsporangium and the wood of the stem, and in the case of Araucaria Rulei to the leaf, there can, I think, be little doubt that the resemblance is an indication of real affinities. One point of resemblance between the two orders, namely, the inversion of the ovule, appears to be due to parallel evolution. The primitive position of the ovule in the Podocarpeae, as Miss Young justly observes, ${ }^{2}$ appears to be erect and axillary, as pointed out in the preceding paragraph.

The only recent paper in which an opposed view is taken is that of Miss Gerry, ${ }^{3}$ who thinks that her work on the distribution of 'bars of Sanio' in the Coniferae indicates a relationship of the Podocarpeae with the Abietineae rather than with the Araucarieae. The evidence consists in the fact that 'bars of Sanio' are recorded as occurring in the tracheides of the xylem, either of stem or root, but not necessarily of both, in all recent Conifers except Araucaria and Agathis. Whether this is actually the case cannot be decided for certain, as, judging from the statements in Miss Gerry's paper, only one species of each genus appears to have been examined (at least no more are described), out of the fourteen species of Araucaria and ten of Agathis. Nor is the additional evidence derived from fossils any more convincing, for although it is stated that 'bars of Sanio' are absent from fossil Araucarian woods and present in woods of an Abietineous affinity, yet the statement means little, for in no case have the so-called Araucarian woods been found in connexion with reproductive organs that are undoubtedly Araucarian, which would alone render certain their reference. As an example of this, mention may be made of Professor Jeffrey's remarks on Geinitzia gracillima. ${ }^{4}$ The 'purely systematic botanists' referred the plant to Sequoia. The author of the paper also says that the cone scales alone, although furnishing him with ample evidence of Araucarian relationships, 'might by those less experienced in the details of Coniferous anatomy still be considered as belonging to the strobili of the Taxodineae or Cupressineae.' Next we learn that 'the pits in no case are contiguous or in more than a single row', which means, of course, that the pitting is

\footnotetext{
1 Young ('07), p. 194.

3 Gerry ('10), p. 122.
}

2 Young ('10), p. 93.

${ }^{4}$ Jeffrey ('11), p. $2 \mathrm{I}$. 
unlike that occurring in undoubted Araucarieae. Nevertheless Professor Jeffrey finds 'bars of Sanio' absent, and so concludes that the plant is one of the Araucarieae, and further that it furnishes 'evidence for the derivation of the Araucarian stock from an ancestry essentially resembling the existing Abietineae'. Sinnott's Paracedroxylon ${ }^{1}$ is regarded as 'a new type of Araucarian wood' for the same reason. Indeed, this reference to an Araucarian affinity seems even more unsatisfactory than that of Geinitzia.

But even if it be allowed that Araucarian wood is characterized by an absence of 'bars of Sanio', it would seem to be an utterly insufficient reason to assert, therefore, the nearer connexion of the Podocarpeae with the Abietineae than with the Araucarieae. In the first place, Miss Gerry's observations go to show that while 'bars of Sanio' are absent in Araucarieae they are not so abundant in the Podocarpeae as in the Abietineae. ${ }^{2}$ Again, it would be quite likely that 'bars of Sanio' should cease to be developed along the Araucarian line of descent and yet remain in the Podocarpean. In fact, when the striking resemblance of the reproductive organs of Saxegothaea and the Araucarieae in more than one respect is considered, together with the less-marked resemblances in the vegetative organs, it must be admitted by every impartial critic acquainted with the facts of the case as they are at present known, that this resemblance far outweighs in phylogenetic value the dissimilarity in the case of the 'bars of Sanio'.

A more difficult question is that regarding the relationship of the Podocarpeae and the Taxeae. A relationship between the two orders has for long been assumed by the retention of both in the one family Taxaceae. $\mathrm{Mr}$. Brooks and the writer in a previous paper ${ }^{3}$ expressed the opinion that evidence of relationship between the two orders was at present not very clear, though Phyllocladus might be a connecting link. M. Tison ${ }^{4}$ has stated that he has evidence that the Taxeae are derived from the Cupressineae, but as far as the writer is aware this evidence has not yet been published. Miss Young's recent work on Phyllocladus shows conclusively, as $\mathrm{Mr}$. Brooks and the writer suggested might be the case, that this genus is one of the Podocarpeae rather than intermediate between that order and the Taxeae. ${ }^{5}$ In the latter the structure of the wood of the stem, the character of the microsporophyll, the position of the ovules in Taxus and Torreya and the number appertaining to one megasporophyll in Cephalotaxus, the absence of prothallial tissue in the male gametophyte, and the absence or poor development of the megaspore membrane ${ }^{6}$ are all characters in marked contrast to the equivalent ones in the Podocarpeae. Our knowledge here is at present inadequate to enable a definite statement to be made ; it

\footnotetext{
1 Sinnott ('09), p. I 70.

3 Brooks and Stiles ('10), p. 3 I6.

5 Young ('10); see also Stiles ('11).
}

2 Gerry ('10), p. 12 I.

4 Tison ('09), p. I 56 .

6 Thomson $\left(' 05^{1}\right)$, p. 43 . 
is at least safe to say that there is as yet little evidence of any near connexion of the Taxeae and Podocarpeae.

Workers on gametophytic structure have found several points of similarity between the Abietineae and Podocarpeae. ${ }^{1}$ In the first place, prothallial cells are developed in the male gametophytes of each order, but whereas these are evanescent structures in the Abietineae, in the Podocarpeae they are generally more numerous and may persist up to the time of fertilization. The distribution and arrangement of the archegonia is also similar, and a third point of resemblance is found in the reduction of the functional male nuclei to one. As regards sporophytic characters, male cones and microsporangia are similarly constructed in the two groups, while in each order the pollen-grains are winged. This last point appears to be another case of parallel evolution, for in the Podocarpeae the wings seem to have arisen within the group itself, for the pollen of Saxegothaea is wingless, while in Microcachrys the wings are imperfectly developed. ${ }^{2}$ Among the Abietineae also the genus Pseudotsuga has wingless pollen. ${ }^{3}$ As regards the distribution of the archegonia we find a similar arrangement in the Taxeae and in Sciadopitys, ${ }^{4}$ while the reduction of the functional males to one is probably to be correlated with the absence of archegonial complexes. $^{5}$ On the other hand, there are great dissimilarities in the structure of the wood of the stem, and in the female fructification. The relative phylogenetic value of different characters is always a difficult thing to estimate, and personal opinions on such a question will probably always vary to some extent. The opinion of most workers is that it is to the reproductive structures, rather than vegetative characters, such as wood structure, that we should look for indications of relationship. In the case under consideration the differences between the simple cone scale of the more primitive Podocarpeae bearing a single ovule, and the more complicated 'pièces du cône' of the Abietineae each bearing two ovules, indicate that the relationship between the two orders cannot be a very near one. On the other hand, there are several characters which seem to indicate a common ancestry of the two orders, chief among which must be reckoned the similarity of the microsporophylls, the distribution of archegonia in the female gametophyte, the development of prothallial tissue in the male gametophyte, and the inversion of the ovules. In the last two instances the facts indicate that the Abietineae have advanced much further from the common ancestor than the Podocarpeae, for the prothallial tissue is reduced not only in amount but also in the length of time it persists, while the inversion of the ovules is much more complete. The position of the ovule on an outgrowth of the scale in Podocarpus, and especially the position

1 Coker ('02), p. I02; Young ('07), p. I94; Burlingame ('08), p. I75.

2 Thomson ('09'), p. 29.

4 Lawson ('10), p. 4I2.

s Lawson ('09), p. I63.

5 Lawson $\left(' 07^{2}\right)$, p. 2 g2. 
of the ovule in Dacrydium cupressinum on the epimatium, which is here developed to a greater extent than the megasporophyll, are very suggestive of a possible origin of the ovuliferous scale in the Abietineae. If the epimatium of Dacrydium cupressinum is called an ovuliferous scale we practically have the state of affairs in the Abietineae. It is, of course, not by any means suggested that Pinus is descended from Dacrydium, nor for that matter that any of the Abietineae have descended from any of the Podocarpeae, or indeed any living Coniferous group from any other as we know them, but Dacrydium and Pinus may have inherited the same potentialities from the same ancestor. These considerations thus suggest that the Abietineae have sprung from the same primitive stock as the Podocarpean-Araucarian phylum, but in the respects mentioned above have developed much further from their common ancestors than the Podocarpeae, while in the formation of perfect cones they have retained a primitive character lost in the more recent Podocarpean genera, but still present in the more primitive members of the order.

The point of view taken in the preceding paragraph involves the derivation of the complicated ovulate structure of the Abietineae from a simple sporophyll. This is, however, not at all a generally accepted hypothesis, for many botanists have thought that the simple cone scale has been derived by reduction from the more complicated double structure.

The view that the single cone scale groups have been derived from ancestors essentially resembling the existing Abietineae depends for its support largely on abnormalities, and on the vascular structure of the cone scales. The abnormalities consist mostly of structures sometimes found in members of the Abietineae in which the normal cone scale is replaced by a bract bearing in its axil a structure more or less like the short shoot of Pinus. ${ }^{1}$ From this it has been argued that the double cone scale of the Abietineae is to be regarded as derived from the fertile equivalent of such a brachyblast shoot, and various well-known modifications of this view have been put forward. ${ }^{2}$ But abnormalities, especially when they are supposed to be more or less of the nature of reversions, afford by themselves unsatisfactory evidence of phylogeny. As to the evidence of the vascular supply of the cone scales, this depends on the fact that in all groups of Conifers there is inverse orientation of the ovular supply as compared with the lower series of bundles serving the sporophyll (or the lower 'bract' scale in the case of the Abietineae). In most cases the ovular supply and sporophyll supply are independent of one another from the cone axis. These facts are supposed to point to the double nature of the apparently single cone scales of the Araucarieae and Podocarpeae, the two scales as we have them in the Abietineae being very closely fused together. The opinion that the facts do not point to this conclusion in the Araucarieae and Podocarpeae

1 See Coulter and Chamberlain ('10), p. 245 et seq.

2 See Worsdell ('00), p. 39. 
has already been expressed by all recent workers on their cone scales, ${ }^{1}$ and the evidence is against the double nature of the cone scale in these groups. Indeed the more primitive Podocarpeae are less like the Abietineae in respect of the cone scale than the more modern ones. There is indeed a suggestion of doubleness in Dacrydium cupressinum and Podocarpus, and here it has most clearly arisen within the group.

So we are left with the alternatives of supposing the forms with double cone scales as derived from a single-scaled ancestor, or of supposing the two lines of descent to be quite distinct. That different groups of Conifers have descended from different Pteridophytic or Pteridospermic ancestors seems to the writer to be quite impossible.

There are at present two views as to the phylogeny of the Conifers: the more popular one that regards the Conifers and Cordaitales as on the same line of descent, and the view that it is in the Lycopodialean alliance that we find the nearest approach to the ancestors of the Coniferae of to-day. Dr. Scott has made out the best case for the origin of the Araucarian alliance from Cordaitales-like ancestors, and the chief points of his argument are as follows : ${ }^{2}$

I. The stem structure of the Araucarieae is Cordaitalean.

2. The roots are like those of Cordaites.

3. The leaves are parallel-veined.

4. The staminate strobili and sporangia are like those of Cordaites.

Now if the Araucarieae and Podocarpeae are such nearly related groups as the writer supposes them, in considering the Cordaitalean origin of the Coniferae the Podocarpeae must be regarded as of as great importance as the Araucarieae.

Now in the first place the stem structure of the Podocarpeae, although of a simple coniferous type, is not at all Cordaitalean, except as regards the distribution of the primary vascular bundles, a point of resemblance which can be extended to many other forms. As regards the wood there is no reason why the Cordaitalean and Podocarpean types of wood should not have been derived from the same type; on the other hand, there is no evidence from this character of a connexion between the two orders.

In the second place the roots of the Podocarpeae, in so far as they have been examined, are not particularly reminiscent of the roots of the Cordaitales. It is true, indeed, that they are no more reminiscent of Lycopod roots; at least they furnish no definite evidence of a Cordaitalean origin. One interesting fact about the roots of the Podocarpeae is the possession of tubercles and mycorrhiza which have been compared by Osborn with the mycorrhiza in Amyelon, the root of Cordaites. He says

1 Seward and Ford ('06); Stiles ('08), p. 218 ; Thomson ('092), p. 352; Tison ('09), p. I55.

${ }^{2}$ Scott ('09), p. 653 . 
'... the Coniferae generally have an ectotropic mycorrhiza. It need not, therefore, be a matter of surprise that their Paleozoic ancestors should have had a similar relationship.' 1 This of course assumes the Cordaitalean origin of the Conifers, but when it is considered of what general occurrence among vascular plants is the presence of mycorrhiza, there seems no reason to regard its presence in two groups as any indication of relationship.

The third point, the parallel venation of the leaves, has been dealt with in a previous section of this paper. ${ }^{2}$ It was there shown that the evidence was in favour of the primitiveness of the single-veined leaf in the Podocarpeae in particular, and the Coniferae in general, so that in this case the evidence is directly against the Cordaitales theory.

Finally, the last piece of evidence supposed to favour the Cordaitalean origin of the Conifers, that the staminate strobili and sporangia of the Araucarieae are like those of the Cordaitales, no more favours this view when the Podocarpeae are taken into consideration, than the three preceding pieces of evidence, for the strobili and sporangia of the Podocarpeae are quite unlike those of the Cordaitales. It is interesting also that Hollick and Jeffrey's fossil cone, Strobilites microsporophorus, which those authors think may be in some ways intermediate between Araucarieae and Abietineae, closely resembles the male cone of the Podocarpeae and is also quite unlike the staminate strobili of Cordaites.

Thus, if it is correct, as it seems to the author, to regard the modern coniferous groups as terminating a bunch of radiating lines of evolution from a common ancestor, it seems quite impossible to regard that ancestor as approaching at all nearly the Cordaitales, for in one group, the Podocarpeae, the more primitive members, which exhibit undoubted resemblances to other groups, Araucarieae and Abietineae, as well as exhibiting other features which must be regarded as primitive, are unlike, in almost every character, the Cordaitales as at present known.

One is therefore led to a consideration of the opposed and rather unpopular view of the Lycopodialean origin of the Conifers. This view has received strong support from Campbell ${ }^{3}$ from a general consideration of the Conifers, and from Seward and Ford ${ }^{4}$ as regards the Araucarieae alone.

The most important piece of evidence in support of this view is derived from a comparison of the cones of the Lycopodiales and the Coniferae. In the Lycopodiales the sporophylls are aggregated into cones, and each sporophyll bears a single sporangium approximately in its axil; in some cases it is true the sporangium arises from stem tissue, but generalizing it may be said that the characteristic of the Lycopodialean phylum is the

\footnotetext{
1 Osborn ('09), p. 608.

3 Campbell ('05), pp. 534, 604.

${ }^{2}$ p. $49^{2}$.

4 Seward and Ford ('06), p. 385.
} 
possession of sporophylls with the single sporangium borne medianly in relation to the sporophyll. ${ }^{1}$

Now in the Podocarpeae and in the Araucarieae, the relation of ovule to megasporophyll is the same. Each sporophyll bears a single sporangium medianly on its upper surface. In most cases in the Podocarpeae the sporangium in its later stages appears on the surface of the sporophyll and not in its axil, and moreover is usually more or less reversed. In every case so far investigated, however, the evidence points to the fact that the sporangium in the very young strobilus does actually arise in the axil of the sporophyll, and in an erect position; it is only later in its ontogeny that it becomes reversed and carried away from the axis. In fact, in the youngest stages, which are almost certainly more primitive than the older, the condition is identical with that in the Lycopodiales. Among the latter the genus Spencerites affords an interesting comparison with the Podocarpeae, for here the sporangium is borne on the upper side of the sporophyll away from the axis, and, moreover, may be regarded as reversed.

The chief evolutionary tendency in the Podocarpeae, as has already been pointed out, is reduction in the number of sporophylls in the female strobilus. What are regarded as the more primitive members of the order still, however, retain their sporophylls in cones, and so approach more nearly the majority of Lycopods than do the more specialized Podocarpeae.

The microsporophylls also are easily comparable with those of the Lycopods. The sporophylls are still aggregated into cones, but whereas in the Lycopods there is constantly a single microsporangium in the axil of each microsporophyll, in the Podocarpeae there are constantly two borne on the under side. This difference is not a very serious one. That septation of a single sporangium into more than one has taken place in other cases is more than probable. Indeed, the two sporangia forming the synangium of Tmesipteris, and the three sporangia in the sporangiophore of Psilotum, are considered by some botanists as derived in this way ${ }^{2}$ from the single sporangium as it exists in the Lycopod, and in Lepidostrobus Brownii and in Isoetes we have cases in which this septation by means of sterilization of formerly sporogenous tissue has proceeded only partially towards completion. ${ }^{3}$ Indeed, such a case of incipient septation may be present in the genus Lycopodium itself, as in Lycopodium clavatum. ${ }^{4}$

The shifting of the sporangia to the under side presents little difficulty to the view under consideration. Shifting of the position of the sporangia in regard to the sporophyll has certainly taken place in other cases. It is possible, though indeed not by any means certain, that in the Ferns the position of the sori has shifted from a marginal to a superficial one. ${ }^{5}$

1 Bower ('08), p. 326.

2 1. c., p. 427.

- Sykes ('08), p. 50, Text-fig. 7, ix.

3 1. c., pp. 326,697 .

5 Bower ('08), p. $66_{3}$. 
Among the Equisetales in Palaeostachya the sporangiophores are found on the upper side of the sporophyll, while in Cingularia the sporangia are below the sporophylls. In this case the value of the analogy is perhaps lessened to some extent through the doubt which exists as to the correct reference to the Equisetales of Cingularia; the argument, however, still holds good if that genus really belongs to the Sphenophyllales. Moreover, if the microsporophylls and megasporophylls are actually homologous with one another, and all workers on the Podocarpeae are agreed that the female scale is actually a simple sporophyll, a shifting of the sporangium to the other side of the sporophyll must have taken place in the evolution of one or other kind of sporophyll; unless, indeed, the homosporous ancestor bore sporangia on both sides of the sporophyll, a state of affairs which, having regard to the relation of sporangia to sporophylls in all orders of the Pteridophyta, one must regard as extremely unlikely.

Nor is the possession of the seed-habit in the Conifers to be regarded as evidence against the Lycopodialean ancestry of these forms, as Professor Seward and Miss Ford have already pointed out. ${ }^{1}$ The seed-habit had already been evolved in the Lycopodiales in Palaeozoic times, as in the cases of Lepidocarpon and Miadesmia; in the recent genus Selaginella, some approach to it appears in Selaginella apus and S. rupestris, ${ }^{2}$ while one of its accompanying phenomena, the reduction of the number of spores in the megasporangium, occurs in several species. ${ }^{3}$ There is thus abundant evidence that the potentiality of seed-production existed in this phylum as well as in the Fern phylum.

The vascular anatomy of the sporophylls affords an interesting comparison between the two orders. In the Lycopods the sporangium supply consists of a single medianly placed vascular bundle. In the living genera there is no special sporangial supply apart from this, but in some species of the genus Lycopodium there is evidence of the remains of a median sporangial supply given off from the upper surface of the sporophyll bundle. ${ }^{4}$ This is the state of affairs which exists in the young state of the megasporophyll in Saxegothaea and Microcachrys ${ }^{5}$ later it is much modified in the former case owing to the development of ovular bundles which attach themselves laterally to the sporophyll bundle. In the more modified fructification of Dacrydium Franklini the central median bundle of the ovular supply is lost, and the lateral bundles alone form the ovular supply; in the species of Podocarpus examined these two lateral supply bundles are carried down into the axis of the strobilus independently of the sporophyll bundle. That this condition is to be accounted for by the greater relative

\footnotetext{
1 Seward and Ford ('06), p. 394.

2 Lyon, F. M. ('01).

${ }^{3}$ Lyon, 1. c., p. I38; Mitchell ('10), p. 24 ; Sykes and Stiles ('10), p. 529.

4 Sykes ('08), p. 43 .

5 Thomson ('092), p. 349 .
} 
importance of the ovule as compared with the sporophyll has already been suggested by Mr. R. B. Thomson, ${ }^{1}$ and by Mr. Brooks and the writer. ${ }^{2}$

The vascular supply of the microsporophyll of the Podocarpeae is just the same as that of the Lycopodiales as far as its distribution is concerned.

As regards vegetative organs further evidence in support of the view under discussion is derived from a consideration of the leaves. The characteristic of the leaves of living Lycopods and many of the fossil ones is their relative smallness and their possession of a single median vascular bundle. Arguments have been advanced already in the course of this paper to show that the primitive type of coniferous leaf was the common uninerved type characteristic of all Conifers except a few Araucarieae and the Nageia section of Podocarpus. Some single-veined Araucarian leaves, it is true, have probably been reduced from broader leaves, ${ }^{3}$ but there is no evidence of this in the leaves of any of the Podocarpeae or of any other order. The slight tendency to form wider leaves with parallel veins, as exhibited in Agathis and Podocarpus $\S$ Nageia, may be compared with the still slighter tendency to the same thing in Sigillaria, where in some species (Sigillariopsis) the leaves were traversed by two parallel veins. ${ }^{4}$

The presence of leaf-gaps in the stele of the Coniferales has been regarded by some botanists as affording important evidence in the consideration of the origin of the Conifers. This line of argument was first used by Professor Jeffrey in 1902, when he inferred that the Coniferales were descended from the Fern-plexus on the ground that foliar gaps occur in the stele of both these groups, but are absent in the Lycopodiales. ${ }^{5}$ Coulter and Chamberlain regard this argument as a very strong one, for in discussing the objections to Seward and Ford's view of the Lycopodialean origin of the Araucarieae they say: 'Perhaps the most fundamental objection is the presence in araucarians of foliar gaps and of wood indistinguishable from that of Cordaitales.' 6

It is clear that this objection is based on the assumption that the presence or absence of leaf-gaps in the stele is a character fixed and unalterable in the phylum, an assumption for which, although it is so generally accepted as a fact, there is no supporting evidence. There certainly is evidence that in the evolution of the Lycopodialean vascular system, just as in the Cycadofilices, ${ }^{7}$ one of the most important tendencies was the elimination of primary centripetal wood. Thus Dr. Scott remarks, 'A gradual transition may be traced from the protostelic type, through the medullated forms of Lepidodendron and the ribbed Sigillarias, to the smoothbarked Sigillarias, in which the ring of wood separates, more or less com-

\footnotetext{
1 Thomson $\left({ }^{\prime} 09^{2}\right)$ p. 35 I.

2 Brooks and Stiles ('10), p. 314.

3 Seward and Ford ('06), p. 350.

4 Arber and Thomas ('08), p. 148 ; Scott ('09), p. ${ }^{2} 3$ o.

5 Jeffrey ('02), p. II 9 .

${ }^{6}$ Coulter and Chamberlain ('10), p. 3 I I.

7 Scott ('02), p. 25.
} 
pletely, into distinct bundles.' ${ }^{1}$ In such a series we have the ancient Lepidodendron pettycurense, ${ }^{2}$ with its solid xylem core, $L$. selaginoides (=L. vasculare $),{ }^{3}$ where parenchyma was intermingled with the tracheides in the middle of the stele, and $L$. Wunschiamum, ${ }^{4}$ where a large pith occupied the middle of the stem, and the primary xylem was reduced to a comparatively small ring surrounding the pith. A further reduction of primary xylem is exhibited in Sigillaria spimulosa, by the partial division of the narrow ring of primary xylem into bundles, and ultimately in S. Menardi the xylem was completely split up into separate bundles, the primary parts of which were very small compared with the size of the stem, for in Brongniart's specimen the pith was about $15 \mathrm{~mm}$. across, while the ring of bundles, the greater part of which was secondary wood, was only about I $\mathrm{mm}$. in thickness. ${ }^{5}$

Thus in the evolution of the Sigillaria Menardi type of stele from the exarch protostele of the earlier Lepidodendrons, such as L. rhodamnense and $L$. pettycurense, the chief tendency has been towards elimination of the primary centripetal wood, which was replaced by secondary centrifugal wood. If we suppose this tendency to have full play we shall at length reach a condition in which the centripetal xylem of the stem has disappeared altogether. The stele in its primary state will then consist of a ring of bundles, each consisting of little more than the proxylem elements, the great mass of wood in the stem being secondary. Under these circumstances it is not only possible but likely that the mode of insertion of the leaf-traces will differ from their mode of insertion on a stele containing much primary centripetal wood.

Thus it appears to the writer that the presence of leaf-gaps in the stele of the Coniferales is a character that cannot be legitimately used as an argument against the derivation of this group of plants from an ancestor without leaf-gaps in the stele.

As regards the structure of the elements themselves the nature of the pitting of the tracheides furnishes an argument against the Lycopodialean ancestry of the Conifers, but here it seems that in Renault's Sigillariopsis Descaisnei there were pitted tracheides as well as scalariform ones, ${ }^{6}$ though the approach to a coniferous type does not seem very near.

The presence of a double leaf-trace in the Abietineae has been looked upon as furnishing an important piece of evidence in favour of the Cordaitalean relationship of the Coniferae. But in a similar way the presence of a single leaf-trace in the Podocarpeae (except Nageia) may be regarded as furnishing equally important evidence in the opposite direction.

Gametophytic and embryonic structures have not been considered in

${ }^{1}$ Scott ('09), p. 634.
3 Scott ('08), p. 146.
3 Scott ('08), p. 215.

2 Kidston ('07), p. 207.

4 Seward and Hill ('00), p. 907, and Seward ('10), p. I64.

6 Renault ('79), p. 270; Scott $\left({ }^{\circ} 08\right)$, p. 230. 
this discussion, as exceedingly little is known about these structures in either Cordaitales or fossil Lycopodiales. It is worthy of note that Campbell, who is most competent to speak on this matter, says, 'In the character of the sporangium and the early development of the prothallium, Selaginella undoubtedly shows the closest affinity to the Spermatophytes, especially the Gymnosperms, of any Pteridophyte.' 1

The phylogenetic importance of the presence of a suspensor in the embryo of both Lycopods and Conifers is now considerably lessened, owing to the discovery of a suspensor in some of the Ophioglossales ${ }^{2}$ and in Danaea. $^{3}$

During the last few years there has been a growing tendency to take for granted the Cordaitalean ancestry of the Coniferales. The favourable reception accorded to this view is no doubt largely due to the acceptance of the Celakovskian or some similar idea of the brachyblast nature of the ovulate structure of the Abietineae. The Abietineae were at first the most prominently studied Conifers, and it was natural to explain the simple cone-scaled forms studied later in terms of the more complex Abietineae. Satisfactory evidence has, however, yet to be produced in favour of the more primitive nature of the double cone scale, and to the writer the evidence seems to point in the reverse direction, namely, to the primitiveness in the Coniferales of a type bearing female cones composed of aggregations of simple sporophylls, each sporophyll bearing a single erect axillary ovule. Such a type is not found to-day, the various coniferous orders having all departed more or less from it in different directions. This supposed primitive Conifer is very suggestive of the Lycopodiales, but is not reminiscent of the Cordaitales. Further discoveries may necessitate a modification or the withdrawal of this view, but the evidence at present available is, in the opinion of the writer, much in favour of the Lycopodialean ancestry of the Conifers.

\section{xvii. SumMary.}

I. Vegetative Organs. In the Podocarpeae the stem in its primary condition contains a ring of endarch collateral vascular bundles, these in some, and perhaps in all, being very small. Generally there is a resin canal in the cortex outside each vascular bundle.

Except in Podocarpus $\S N a g e i a$ the leaf-trace consists of a single strand. In Podocarpus nagi there is a triple leaf-trace.

Except in Podocarpus $\S$ Nageia there is a single median vascular bundle throughout the length of the leaf. This strand is accompanied by two lateral masses of transfusion tracheides, and usually by a single resin canal on the under or phloem side. Sometimes this single canal is replaced by three

1 Campbell ('05), p. 534.

2 Lyon, H. L. ('05), p. 455 ; Bower ('08), p. 47 I ; Lang ('10), p. 6 I 1.

3 Campbell ('09), p. 69 I. 
canals. In Nageia the leaf is parallel-veined, but each bundle is accompanied by transfusion tissue and a single resin canal as in the single-veined species. In the larger leaved species of the latter accessory transfusion tissue is developed.

2. Spore-producing Members. The male cones are very uniform structures throughout the Podocarpeae, each cone consisting of a number of usually spirally arranged sporophylls, each of which bears two microsporangia. In Saxegothaea the microspores are without wings; in Microcachrys the wings are variable in number and ill-developed; in Phyllocladus, Dacrydium, and Podocarpus there are usually two wings on the microspore, though cases are known in which there are three wings.

The megasporophylls are characterized by the constant relation of one median ovule to the sporophyll. There can be little doubt that the original position of this was an erect axillary one, a position retained to-day by Pherosphaera and probably Phyllocladus. In most of the genera there has been a considerable alteration from this position due to intercalary growth at the base of the sporophyll. This has resulted in Saxegothaea and Microcachrys in the inversion of the ovule, and its removal to a situatic a on the upper surface of the sporophyll remote from the axis. Probably correlated with the inversion of the ovule is the development of the incomplete outer integument or epimatium. In some species of Dacrydium the ovule has shifted its position so as to be inserted on the epimatium. In Podocarpus fusion of parts has taken place, the integument, epimatium, and nucellus being partly fused in Eupodocarpus; the fusion has proceeded further in Nageia, and to the greatest extent in Dacrycarpus. Another novelty in Podocarpus is the development of the ovular stalk. This may be regarded as a further development of the epimatium. In Phyllocladus, where the ovule has retained its erect position, there has resulted the development of a second integument which symmetrically surrounds the inner one.

Another evolutionary tendency has been towards the reduction of the female cone to a single fertile sporophyll.

3. Gametophytes. The female prothallus has been examined in Podocarpus, Dacrydium, and Phyllocladus. The archegonia occur at the apical end of the prothallus, and as far as at present known to the number of from one to four in Phyllocladus and Dacrydium, from five to ten in Podocarpus coriaceus and $P$. macrophyllus to as many as nineteen in $P$.nagi. Each archegonium is surrounded by a separate layer of jacket-cells, but in the species examined cases have been observed of two or more archegonia surrounded by a common jacket, and this may be the rule in $P$. nagi; a sufficient number of cases has, however, not been examined.

The male gametophyte is characterized by the development of several prothallial cells. These vary in number from two, the usual number in Phyllocladus, to eight, a common number in Podocarpus. The pollen-tubes 
in Podocarpus are remarkable for their large size and the extent of their branching between the nucellus and the prothallus. The body-cell nucleus divides into two male nuclei, only one of which is functional.

4. A short account is given of the present state of our knowledge of the Embryology, Seedling Structure, and Geographical Distribution of the Podocarpeae, and of the records of fossil plant remains referred to the order.

5. Theoretical Considerations. An attempt is made to show the probable lines of evolution in the Podocarpeae, and that the Podocarpeae are probably related to the Araucarieae, and, though to a much less extent, to the Abietineae. Evidence has yet to be produced before a close connexion between the Podocarpeae and Taxeae can be recognized. A consideration of the available evidence shows that there is much to be said for the view that regards the Coniferales as descendants of Palaeozoic Lycopodialean ancestors.

The University, LEEDS.

\section{LITERATURE.}

Arber, Agnes: On the Structure of the Palaeozoic Seed Mitrospermum compressum (Will.). Annals of Botany, vol. xxv, I9IO.

Arber, E. A. N., and Thomas, H. H.: On the Structure of Sigillaria scutellata, Brongn., and other Eusigillarian Stems, in Comparison with those of other Palaeozoic Lycopods. Phil. Trans. Roy. Soc. London, ser. B, vol. cc, I908, p. I33.

Archer, W. : Note on Microcachrys, Hook. fil., and on a new allied Genus of Coniferae of Van Diemen's Land. Hooker's Journal of Botany and Kew Garden Miscellany, vol. ii, 1850, p. $5 \mathrm{I}$.

Baker, R. T., and Smith, H. G. : A Research on the Pines of Australia. Sydney, 19 ro.

BERNARD, C. : Le bois centripète dans les feuilles de Conifères. Beihefte zum Botanischen Centralblatt, Bd. xvii, 1904, p. 24 I.

: Le bois centripète dans les bractées et dans les écailles des Conifères. Beihefte zum Botanischen Centralblatt, Bd. xxii, 1907, p. 2 I I.

Berry, E. W.: The American Species referred to Thinnfeldia. Bull. Torrey Bot. Club, vol. xxx, $1903, \mathrm{p} \cdot 438$.

: A Revision of the Fossil Plants of the Genus Nageiopsis of Fontaine. Proc. U. S. National Museum, vol. xxxviii, I910, p. I85.

Bertrand, C. E. : Anatomie comparée des tiges et des feuilles chez les Gnétacées et les Conifères. Ann. des Sciences Naturelles, Botanique, sér. 5, vol. xx, I874, p. 5 . : Étude sur les téguments séminaux des Végétaux Phanérogames

Beust, F.: Untersuchungen über fossile Hölzer aus Grönland. Allgem. Schweiz. Gesellschaft, neue Denkschrift, Bd. xxix, I884.

BlackWell, E. W. : see LAING and BlackWell ('06).

Bower, F. O. : The Origin of a Land Flora. London, 1908.

Brooks, F. T., and Stiles, W.: The Structure of Podocarpus spinulosus, (Smith) R.Br. Annals of Botany, vol. xxiv, 1910, p. 305 .

Burlingame, L. L.: The Staminate Cone and Male Gametophyte of Podocarpus. Bot. Gazette, vol. xlvi, I908, p. I6I.

Campbell, D. H. : Mosses and Ferns. New York, 1905. p. 69 I.

Annals of Botany, vol. xxiii, I909, 
Chamberlain, C. J., see Coulter and Chamberlain ('10).

Chrysler, M. A., see JeFFrey and Chrysler ('07).

Coker, W. C. : Notes on the Gametophytes and Embryo of Podocarpus. Bot. Gazette, vol. xxxiii, 1902, p. 89 .

: On the Gametophytes and Embryo of Taxodium. Bot. Gazette, vol. xxxvi, I 903 , p. I.

Coulter, J. M., and Chamberlain, C. J. : Morphology of Gymnosperms. Chicago, igro.

de Fraine, E., see Hill and de Fraine ('08).

Eichler, A. W.: Coniferae, in Engler, A., und Prantl, K., Die natürlichen Pflanzenfamilien, ii, I, I 889, p. 28.

Endlicher, S.: Synopsis Coniferarum. Sangalli, 1847.

Ettingshausen, C. von. Beiträge zur Kenntniss der Tertiärflora Australiens. Denksch. der math.naturwiss. Classe der Kaiserlichen Akad. der Wissenschaften, Wien, Bd. liii, I886, p. 8I. : Beiträge zur Kenntniss der fossilen Flora Neuseelands. Denksch. der p. 143 .

Favre, E.: Recherches sur la fleur femelle du Podocarpus sinensis. Ann. Sci. Nat., Bot., sér. 5, vol. iii, 1865 , p. 379 .

Fontaine, W. M. : The Potomac or Younger Mesozoic Flora. Monogr. U. S. Geol. Survey, xv, I 889 , p. I 94 .

Ford, S. O., see SEWARD and Ford ('06).

Forster, G. : De Plantis Esculentis Insularum Oceani Australis commentatio botanica. Berolini, I 786 .

Gardner, J. S.: A Monograph of the British Eocene Flora. Vol. ii, Gymnospermae. London, I $883-6$.

Gärtner, J. : De Fructibus et Seminibus Plantarum, Tom. i. Stutgardiae, i 788.

Gerry, E. : The Distribution of the 'Bars of Sanio' in the Coniferae. Annals of Botany, vol. xxiv, 1910, p. II9.

Geyler, T. H.: Einige Bemerkungen über Phyllocladus. Abhandl. Senckenberg. Naturforsch. Gesellsch., xii, I 88 I.

Goebel, K.: Organography of Plants. Eng. ed., vol. i, Oxford, I900.

- Organography of Plants. Eng. ed., vol. ii, Oxford, 1905.

Gothan, W.: Zur Anatomie lebender und fossiler Gymnospermen-Hölzer. Abhandl. Königl. Preuss. Geol. Landesanstalt, Heft xliv, 1905.

: Die fossilen Hölzer von König Karls Land. Kungl. Svenska Vetenskapsakademiens Handlingar, Bd. xlii, No. I0, I907.

: Die fossilen Hölzer von den Seymour- und Snow Hill-Inseln. Wissenschaftliche Ergebnisse der Schwedischen Südpolar-Expedition 190I-3, Bd. iii, Lieferung 8, Stockholm, 1908 .

IIIll, A. W., see Seward and Hill ('00).

Hill, T. G., and de Fraine, E.: On the Seedling Structure of Gymnosperms, I. Annals of Botany, vol. xxii, I908, p. 689 .

Hollick, A., and JefFrey, E. C. : Studies of Cretaceous Coniferous Remains from Kreischerville, New York. Mem. New York Bot. Gard,, vol. iii, New York, 1909.

Hooker, Sir J. D.: On the Huon Pine, and on Microcachrys, a New Genus of Coniferae from Tasmania. London Journal of Botany, vol. iv, 1845 .

: Flora of Tasmania, in The Botany of the Antarctic Voyage, iii, I, London, 1860.

Hooker, Sir W. J. : Icones Plantarum. Vol. vi (New Series, vol. ii), I843.

Jeffrey, E. C. : The Structure and Development of the Stem in Pteridophytes and Gymnosperms. Phil. Trans. Roy. Soc. London, vol. cxcv, I902, p. 119.

: Comparative Anatomy of the Gymnosperms and their Allies. In Coulter, J. M., and Chamberlain, C. J., Morphology of Angiosperms, chap. xvi, 1903, p. 296.

: The Comparative Anatomy and Phylogeny of the Coniferales. Part II. The Abietineae. Mem. Boston Soc. Nat. Hist., vol. x, no. I, 1905 .

- The Wound Reactions of Brachyphyllum. Annals of Botany, vol. xx, 1906, p. 383 . see Hollick and JeFFrey ('09). 
Jeffrey, E. C. : The Affinities of Geinitzia gracillima. Bot. Gazette, vol. li, I9I I, p. 2 I.

, and Chrysler, M. A.: The Microgametophyte of the Podocarpineae. Amer. Nat., vol. xli, I907, p. 355 .

KIDston, R. : On the Internal Structure of Sigillaria elegans of Brongniart's 'Hist. des vég. fossiles'. Trans. Roy. Soc. Edin., vol. xli, I905 p. 533.

: Note on a New Species of Lepidodendron from Pettycur (Lepidodendron pettycurense). Proc. Roy. Soc. Edinburgh, vol. xxvii, I907, p. 207.

KIRK, A. : The Forest Flora of New Zealand. Wellington, N. Z., r889.

KubArt, B. : Podocarpoxylon Schwendae, ein fossiles Holz vom Attersee (Oberösterreich). Osterr. bot. Zeitsch., No. 5, I9I I, p. I6r.

Labillardière, J. J. : Novae Hollandiae Plantarum Specimen. Vol. ii, Paris, 1806.

Laing, R. M., and Blackwell, E. W. : Plants of New Zealand. Christchurch, \&c., N. Z., 1906.

Lambert, A. B. : A Description of the Genus Pinus. London, 1803.

: A Description of the Genus Pinus. Vol. ii, London, i824.

: A Description of the Genus Pinus. Ed. 2, vol. ii, London, 1832 .

LANG, W. H. : On a Suspensor in Helminthostachys zeylanica. Annals of Botany, vol. xxiv, I9Io, p. 6 II.

Lawson, A. A.: The Gametophytes, Archegonia, Fertilization, and Embryo of Sequoia sempervirens. Annals of Botany, vol. xviii, I904 ${ }^{1}$, p. I.

: The Gametophytes, Fertilization, and Embryo of Cryptomeria japonica. Annals of Botany, vol. xviii, $1904^{2}$, p. 4 I 7 .

: The Gametophytes, Fertilization, and Embryo of Cephalotaxus drupacea. Annals of Botany, vol. xxi, $1907^{1}$, p. I.

: The Gametophytes and Embryo of the Cupressineae with special reference to Libocedrus decurrens. Annals of Botany, vol. xxi, $1907^{2}$, p. $28 \mathrm{I}$.

: The Gametophytes and Embryo of Pseudotsuga Douglasii. Annals of Botany, vol. xxiii, I909, p. 163.

- : The Gametophytes and Embryo of Sciadopitys verticillata. Annals of Botany, vol. xxiv, 1910, p. 403 .

Lindley, J. : A Natural System of Botany. Second ed., London, i 836.

: Notice of Certain Ornamental Plants lately introduced into England. Journ. Hort.

Soc., vol. vi, 185 I, p. 258.

: Paxton's Flower Garden. Vol. ii, $185^{2}$.

: The Vegetable Kingdom. Third ed., London, i 853 .

Lyon, F. M. : A Study of the Sporangia and Gametophytes of Selaginella apus and Selaginella rupestris. Bot. Gazette, vol. xxxii, 1901, pp. $124,170$.

Lyon, H. L. : A New Genus of Ophioglossaceae. Bot. Gazette, vol. xl, 1905, p. 455.

Mitchell, G.: Contributions towards a Knowledge of the Anatomy of the Genus Selaginella. V. The Strobilus. Annals of Botany, vol. xxiv, I9 10, p. I9.

Miyake, K.: The Development of the Gametophytes and Embryology in Cunninghamia sinensis. Beihefte zum Bot. Centralblatt, Bd. xxvii, Abt. i, Heft I, p. I, March Io, I9I I.

Nathorst, A. G. : Beiträge zur fossilen Flora Schwedens. Stuttgart, 1878.

: Palaeobotanische Mitteilungen. 7. Ueber Palissya, Stachyotaxus, und Palaeo. taxus. Kongl. Svenska Vetenskap. Acad. Handl., Bd. xliii, No. 8, December, 1908.

Noelle, W.: Studien zur vergleichenden Anatomie und Morphologie der Koniferwurzeln mit Rücksicht auf die Systematik. Bot. Zeitung, Bd. lxviii, I910, p. I69.

Norén, C. O.: Zur Kenntniss der Entwicklung von Saxegothaea conspicua, Lindl. Svensk Bot. Tidskrift, ii, 1908, p. IоI.

Oliver, F. W.: The Ovules of the Older Gymnosperms. Annals of Botany, vol. xvii, I903, p. 45 I. , and Salisbury, E. J. : On the Structure and Affinities of the Palaeozoic Seeds of the Conostoma group. Annals of Botany, vol. xxv, I9II, p. I.

Osborn, T. G. B. : The Lateral Roots of Amyelon radicans, Will., and their Mycorrhiza. Annals of Botany, vol. xxiii, I909, p. 603.

Parlatore, F. : Studi organografici sui fiori e sui frutti delle Conifere. Firenze, 1864.

Penhallow, D. P.: The Anatomy of the Coniferales. Amer. Nat., vol. xxxviii, 1904.

: A Manual of the North American Gymnosperms. Boston, U.S.A., 1907.

Persoon, C. H. : Synopsis Plantarum, pars 2. Parisiis Lutetiorum et Tubingae, 1807. 
Pilger, R. : Taxaceae, in Engler, A., Das Pflanzenreich, iv, 5, Leipzig, I903.

Renault, B. : Structure comparée de quelques tiges de la Flore Carbonifère. Nouv. Arch. Mus. $2^{\mathrm{e}}$ Série vol. ii, I879, p. 2 I 3.

Richard, L. C. and A. : Commentatio botanica de Coniferis et Cycadeis. i 826.

Robertson, A. (see also Arber, Agnes): Some Points in the Morphology of Phyllocladus alpinus, Hook. Annals of Botany, vol. xx, I906, p. 259.

Salisbury, E. J., see Oliver and Salisbury ('11).

Saxton, W. T.: Contributions to the Life-History of Callitris. Annals of Botany, vol. xxiv, I9Io, p. 557.

Schenk, in Zittel, K. A. von : Handbuch der Palaeontologie. Abt. ii, München, I 890.

Scott, D. H. : The Old Wood and the New. New Phytologist, vol. i, I902, p. 25.

- Studies in Fossil Botany. Vol. i, Pteridophyta. London, I908.

: Studies in Fossil Botany. Vol. ii, Spermophyta. London, I9o9.

: Presidential Address to the Linnean Society of London. Proc. Linn. Soc., I9Io.

Seward, A. C. : Catalogue of the Mesozoic Plants in the Department of Geology, British Museum. The Wealden Flora, Part II : Gymnosperms. London, I 895 .

: Catalogue of the Mesozoic Plants in the Department of Geology, British Museum.

The Jurassic Flora, I : The Yorkshire Coast. London, I900.

: Fossil Plants. Vol. ii, Cambridge, I9 Io.

: The Jurassic Flora of Yorkshire ; Presidential Address to the Yorkshire Naturalists'

Union, 1910. Naturalist, I9I I, pp. I, 8I.

, and Ford, S. O. : The Araucarieae, Recent and Extinct. Phil. Trans. Roy. Soc.

London, ser. B, vol. cxcviii, I906, p. 305.

, and Hill, A. W.: On the Structure and Affinities of a Lepidodendroid Stem.

Trans. Roy. Soc. Edinburgh, vol. xxxix, I900, p. 907.

Shibata, K. : Cytologische Studien über die enclotrophen Mycorrhizen. Jahrb. f. wiss. Bot., Bd. xxxvii, 1902, p. 643 .

Sinnotr, E. W.: Paracedroxylon, a New Type of Arancarian Wood. Rhodora, vol. xi, I 909, p. 165.

SMith, H. G., see BAKER and Smith ('10).

Stiles, W. : The Anatomy of Saxegothaea conspicua, Lindl. New Phytologist, vol. vii, 1908, p. 209.

- see BRooks and STILES ('10).

- see Sykes and Stiles ('10).

- : A Note on the Gametophytes of Dacrydium. New Phytologist, vol. x, I9I I, p. 342.

Stopes, M. C. : Beiträge zur Kenntnis der Fortpflanzungsorgane der Cycadeen. Flora, Bd. xciii, Heft $4, \mathrm{I} 904$, p. 435 .

Strasburger, E. : Die Coniferen und die Gnetaceen. Jena, r872.

: Die Angiospermen und die Gymnospermen. Jena, I 879.

Sykes, M. G. : Notes on the Morphology of the Sporangium-bearing Organs of the Lycopodiaceae. New Phytologist, vol. vii, I908, p. 4I.

: The Anatomy and Morphology of the Leaves and Inflorescences of Welwitschia mirabilis. Phil. Trans. Roy. Soc. London, Series B, vol. cci, I910, p. I79.

, and Stiles, W. : The Cones of the Genus Selaginella. Annals of Botany, vol. xxiv, 1910, p. 523 .

Thibout, E. : Recherches sur l'appareil mâle des Gymnospermes. Lille, 1896 .

Thomas, H. H., see Arber and Thomas ('08).

Tноmson, R. B. : The Megaspore-Membrane of the Gymnosperms. University of Toronto Studies, Biological Series, No. 4 , Toronto, $1905^{1}$.

: Preliminary Note on the Araucarineae. Science, N.S., vol. xxii, $1905^{2}$, p. 88.

: The Araucarieae-a Protosiphonogamic Method of Fertilization. Science, N. S., vol. $\mathrm{xxv}, \mathrm{I} 907$, p. $27 \mathrm{I}$.

: On the Pollen of Microcachrys tetragona. Bot. Gazette, vol. xlvii, 1909', p. 26.

: The Megasporophyll of Saxegothaea and Microcachrys. Bot. Gazette, vol. xlvii,

$1909^{2}$, p. 345 .

Thunberg, L. P.: Flora Japonica. Lipsiae, I 784 .

Tison, A. : La nucelle stigmatifère et la pollinisation chez le Saxe-Gothaea conspicua. Comptes Rendus, vol. cxlvii, I908, p. I 37 . 
Tison, A. : Sur le Saxe-Gothaea, Lindl. Mém. de la Soc. Linn. de Normandie, tom. xxiii, 1909, p. I 39 .

VAHL, M., see WARMing and VAHL ('09).

Van Tieghem, P.: Anatomie comparée de la fleur femelle et du fruit des Cycadées, des Conifères et des Gnétacées. Ann. des Sci. Nat., Bot., sér. 5, vol. x, I869, p. 269.

: Recherches sur la symétrie de structure des plantes vasculaires. Ann. des Sciences Naturelles, Bot., sér. 5 , vol. xiii, 1870 , p. I.

Warming, E., and VAhl, M. : Oecology of Plants, an Introduction to Plant Communities. Oxford, r 909 .

Worsdell, W. C. : On Transfusion Tissue. Trans. Linn. Soc., ser. 2, vol. v, I897, p. 30 I.

: Observations on the Vascular System of the Female 'Flowers' of the Coniferae. Annals of Botany, vol. xiii, I899, p. 527 .

: The Structure of the Female 'Flower' in Coniferae. Annals of Botany, vol. xiv, I900, p. 39.

Young, M. S.: The Male Gametophyte of Dacrydium. Bot. Gazette, vol. xliv, I907, p. I89.

: The Morphology of the Podocarpineae. Bot. Gazette, vol. 1, 1910, p. 8I.

Zeille R, R. : Bassin houiller et permien de Brive : flore fossile, $189^{2}$.

\section{EXPLANATION OF FIGURES IN PLATES XLVI-XLVIII.}

Illustrating Mr. Stiles's paper on the Podocarpeae.

[Figs. 5 and 10 are from photographs by Miss E. Ramsden, and Fig. 24 is from a drawing by Miss E. J. Welsford, University of Leeds. Figs. I-4, 6-9, and I I-I 4 are from photomicrographs, and Figs. $15^{-2} 3$ and $25^{-32}$ are from drawings made by means of a Zeiss-Abbé camera lucida.]

\section{PLATE XLVI.}

Fig. I. Podocarpus andinus. Transverse section through stem in primary condition.

Fig. 2. P. elongatus. Transverse section through stem shortly after the commencement of secondary thickening.

Fig. 3. P. nagi. Transverse section through stem in primary condition.

Fig. 4. P. nagi. The same a little higher up, showing the three vascular bundles of the leaf-base.

Fig. 5. $P$. andinus. Branch bearing male cones.

Fig. 6. P. andinus. Transverse section through microsporophyll.

Fig. 7. Saxegothaea conspicua. Transverse section through axis of female cone. nucellus.

Fig. 8. S. conspicua. Transve:se section through ovule, showing epimatium, integument, and

Fig. 9. Microcachrys tetragona. Longitudinal section through megasporophyll.

Fig. 10. Podocarpus macrophyllus. Branch bearing leaves and female fructification. ov., ovule; rec., receptacle.

Fig. I I. P. latifolius. Longitudinal section through young female fructification.

Fig. I 2. P. macrophyllus. Transverse section through radicle of embryo.

Fig. 13. P. macrophyllus. Transverse section through cotyledons of embryo.

Fig. 14. P. macrophyllus. Longitudinal section through embryo.

\section{PLATE XLVII.}

Figs. 15-16. Podocarpus andinus. Leaf-traces in transverse section. $\times 200$.

Fig. 17. P. amarus. Transverse section of primary vascular bundle in the stem. $\times 200$.

Fig. 18. P. nagi. Transverse section of primary vascular bundle in the stem. $\times 200$.

Fig. 19. Dacrydium cupressinum. Juvenile leaf, transverse section of vascular bundle. $\times 200$.

Fig. 20. D. cupressinum. Adult leaf, transverse section of vascular bundle. $c_{\text {., }}$ canal; ph., phloem; t.t., transfusion-tissue. $\times 200$.

Fig. 21. Podocarpus nagi. Transverse section of concentric bundle at the base of the petiole. $\times 200$. 
Fig. 22. Dacrydium Franklini. Transverse section (in outline) through megasporophyll and young ovule. s.s., sporophyll supply bundle; $r$., resin-canal; o.s., ovular supply bundle; $e_{\text {., }}$ epimatium; $i$., integument ; $n$., nucellus ; $g$., gametophyte.

Fig. 23. Podocarpus latifolius. Transverse section through vascular bundle of megasporophyll.

Fig. 24. P. nagi. Part of a stem with leaves and female fructifications. Natural size.

\section{PLATE XLVIII.}

Fig. 25. Dacrydium cupressinum. Longitudinal section through the apical part of the nucellus of an ovule. The upper parts of two pollen-tubes are shown containing the body-cell and several small nuclei. $\times 440$.

Fig. 26. D. cupressinum. Longitudinal section through middle region of the nucellus of an ovule, showing the lower part of a pollen-tube in which the tube-nucleus has divided. $\times 375$.

Fig. 27. Podocarpus macrophyllus. General view of the apical part of the nucellus, showing the depression at the top, and a single pollen-tube with body-cell and two smaller nuclei. $\times 96$.

Fig. 28. P. macrophyllus. The same with several pollen-tubes. In one tube the body-cell is still undivided; in another the male nuclei are present. $\times 80$. nuclei.

Fig. 29. P. macrophyllus. The functional and non-functional male nuclei with three small

Fig. 3o. P. macrophyllus. A section throngh the cytoplasm surrounding the same body-cell as that shown in Fig. 29, and showing three more small nuclei.

Fig. 31. P. macrophyllus. Apical part of an archegonium just before fertilization. $\times 235$.

Fig. 32. P. macrophyllus. Two pro-embryos, one undergoing the division from 4 to 8 nuclei, the other in the I6-nucleate stage. Only the nuclei seen in one section are shown. $\times$ I 50 . 


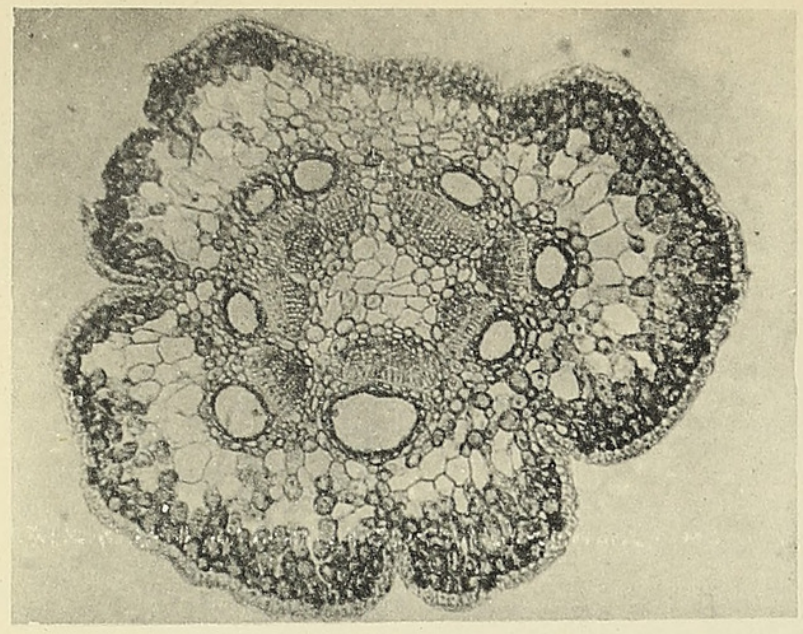

1 .

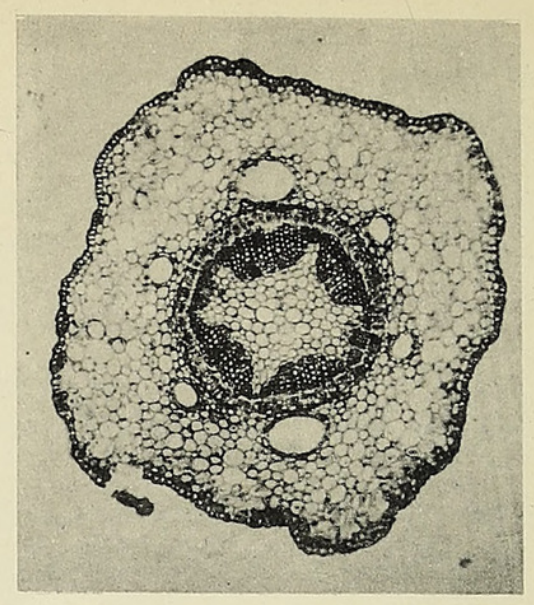

2.

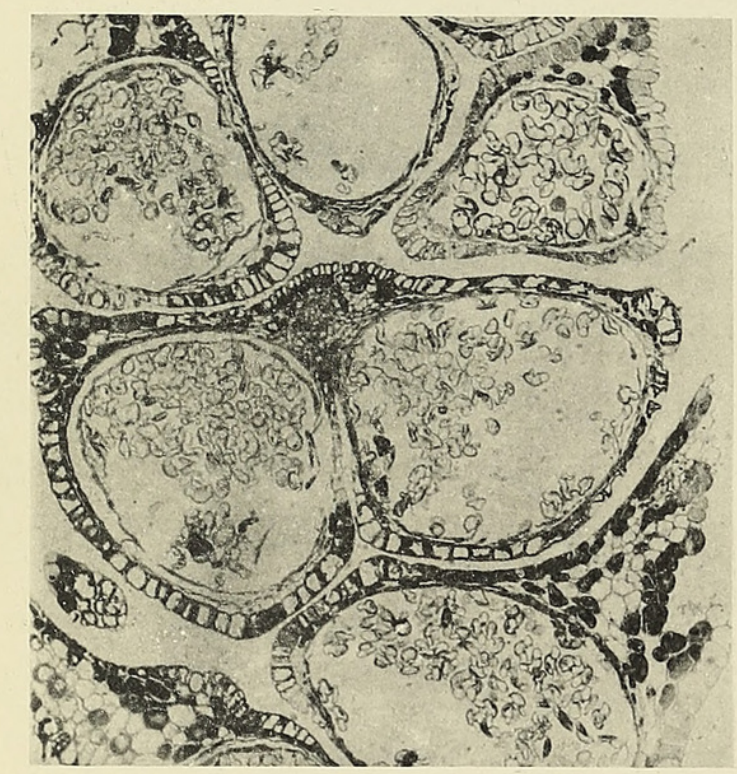

6.

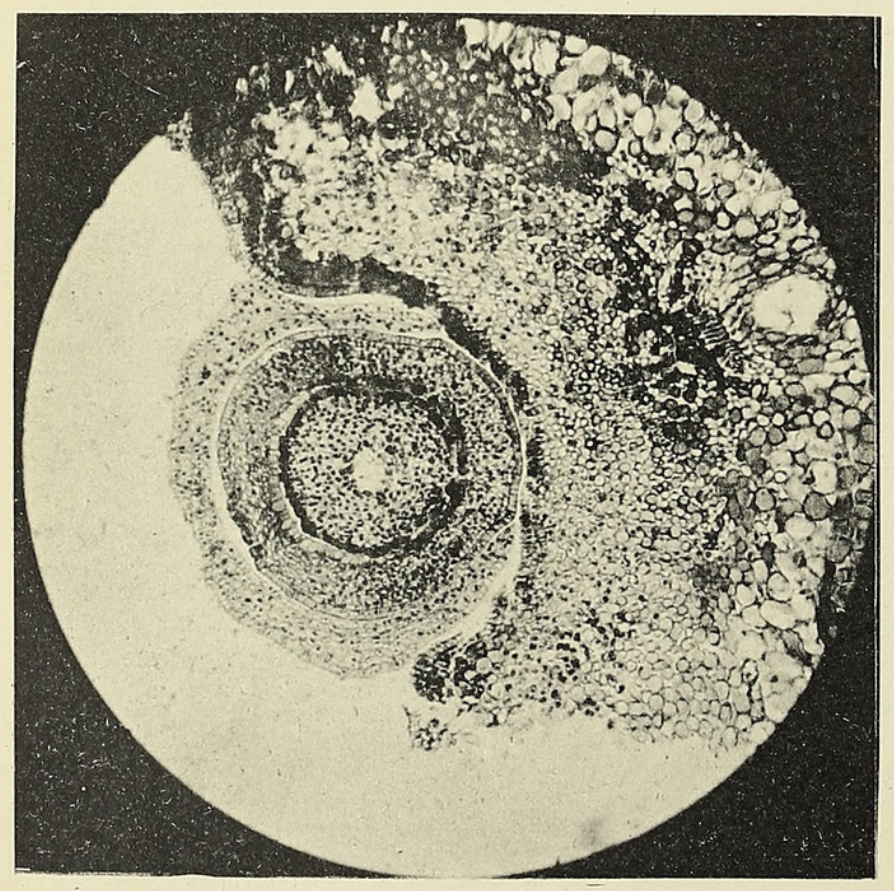

8.
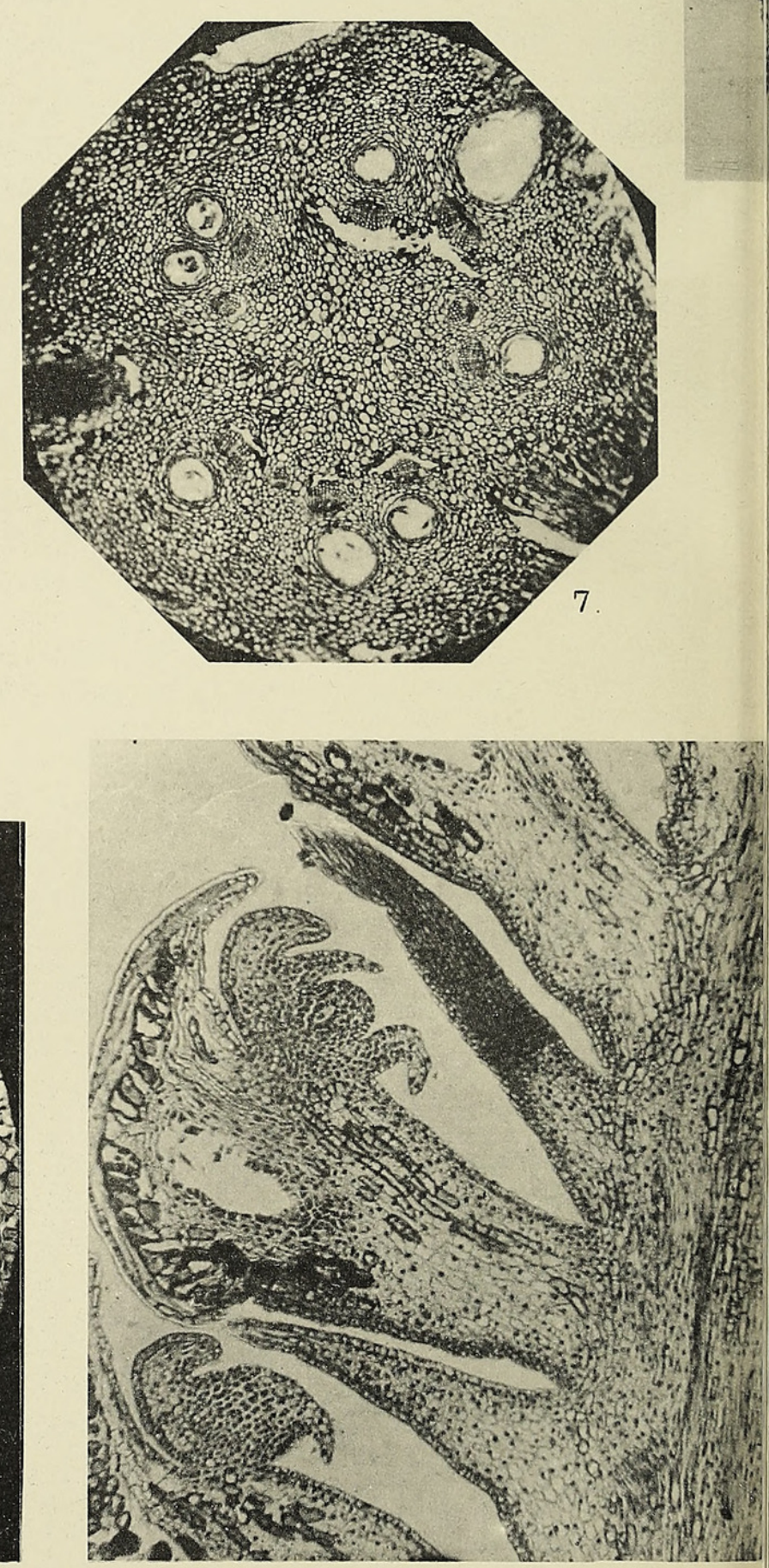

9 
Vol.XXVI. Pl. XLVI.
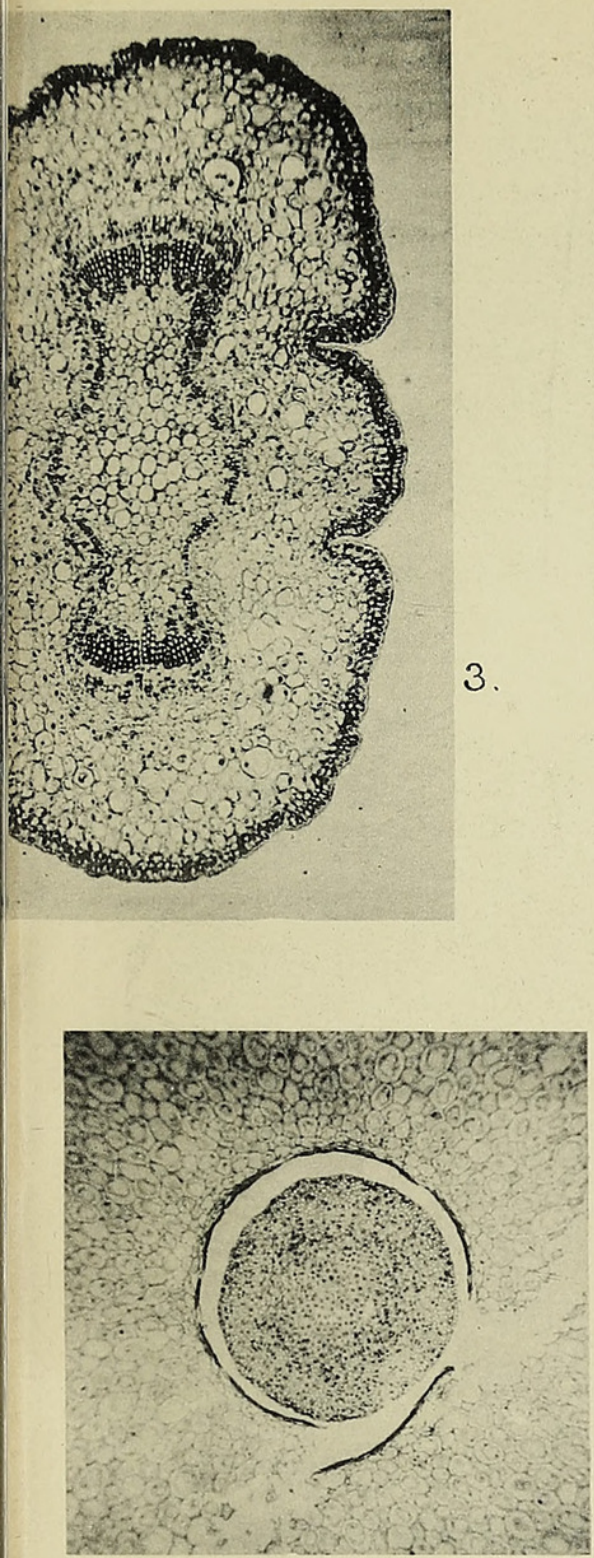

12

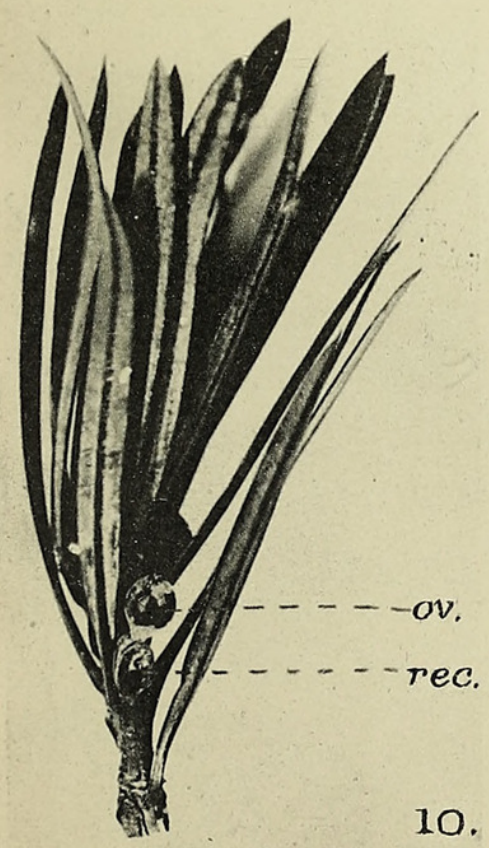

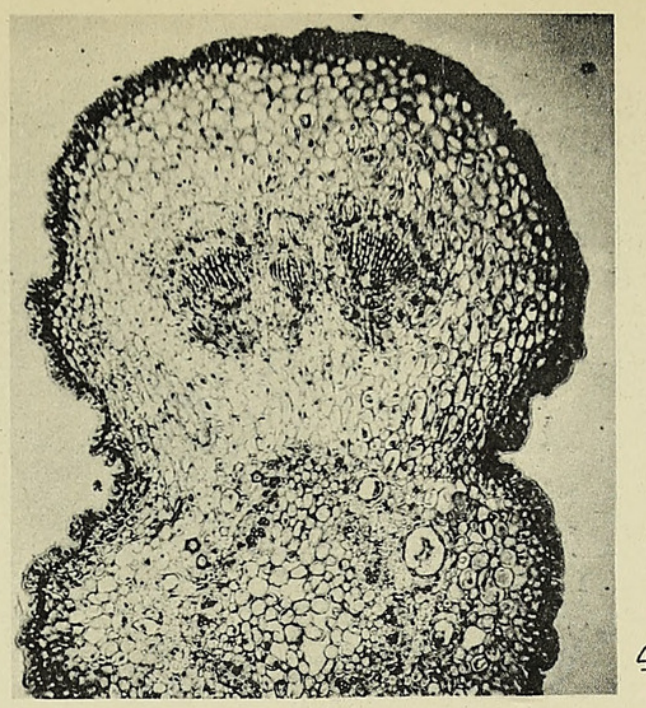

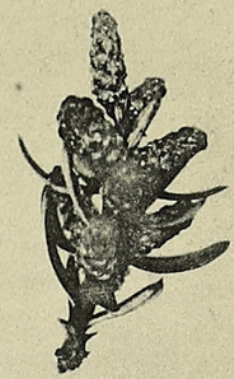

5.
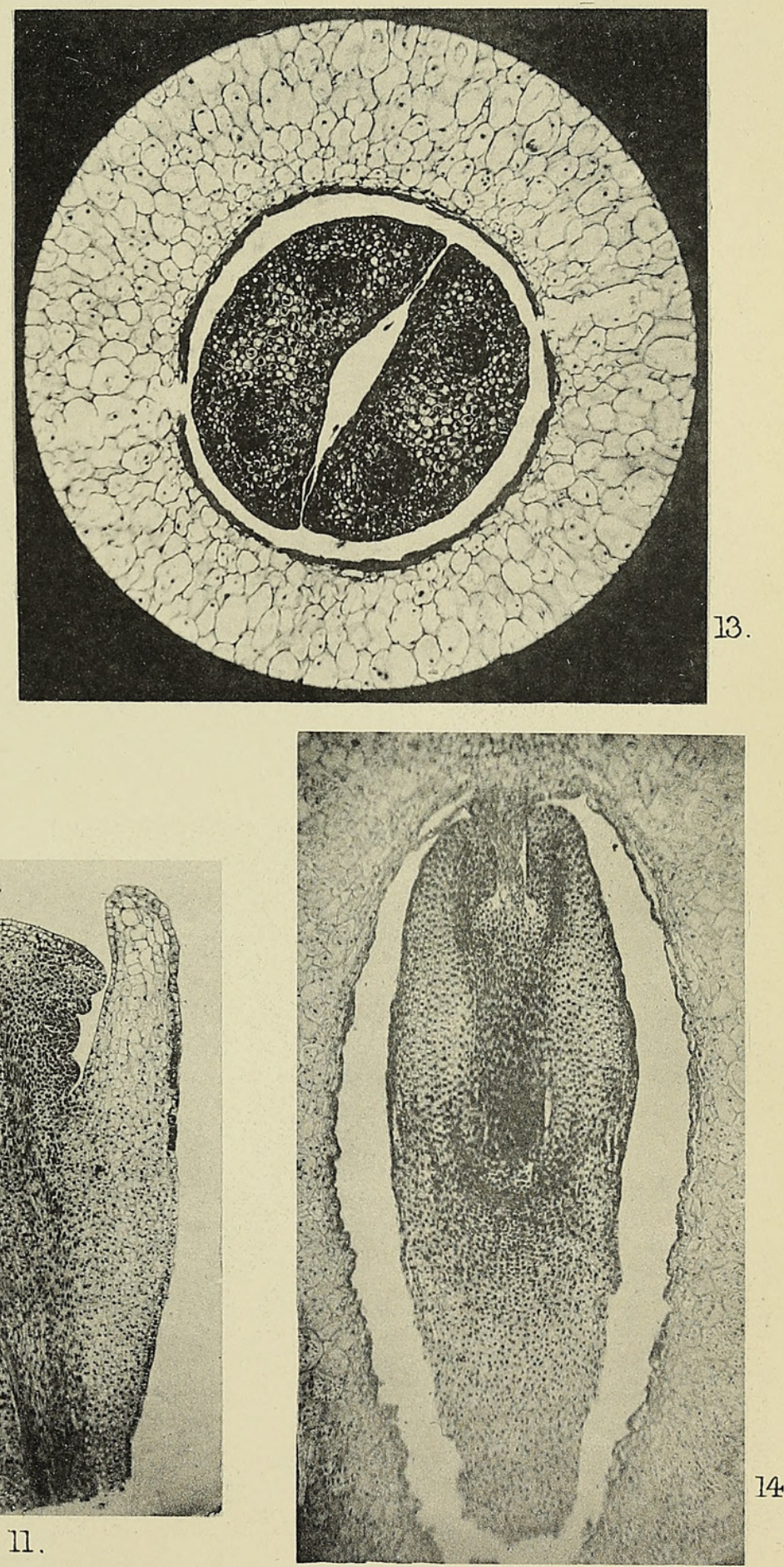

11. 

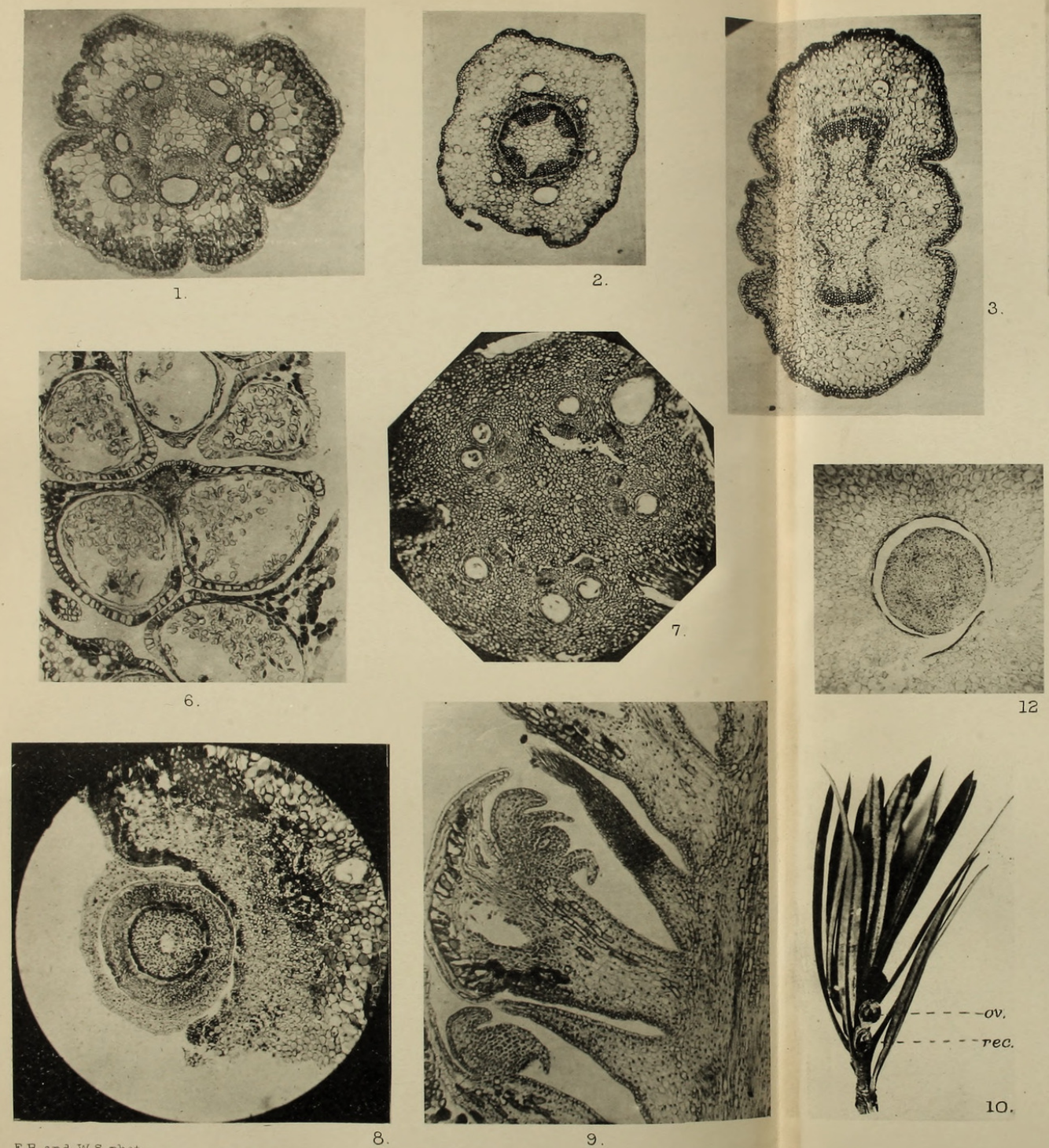
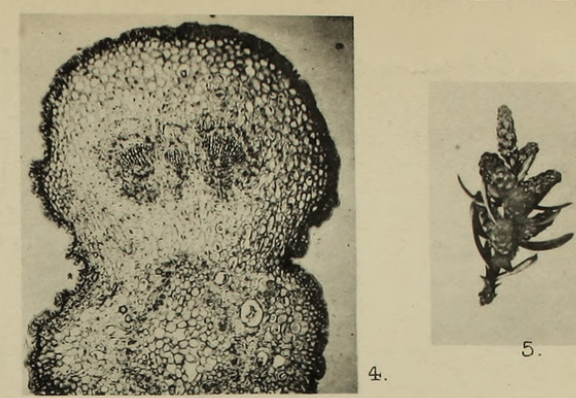
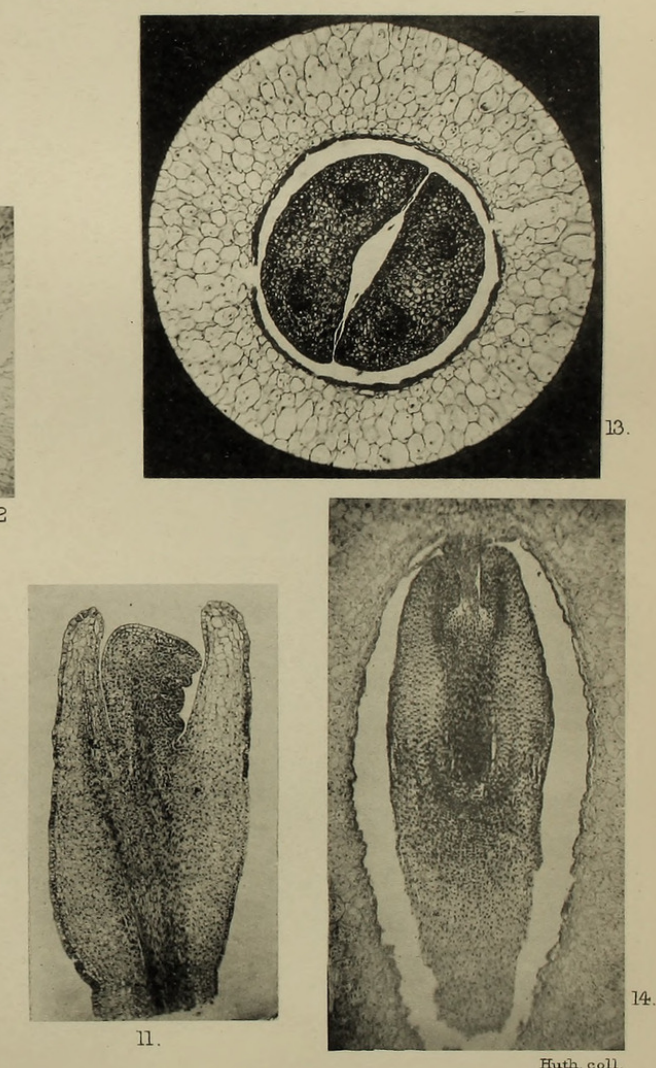
Annals of Botany.
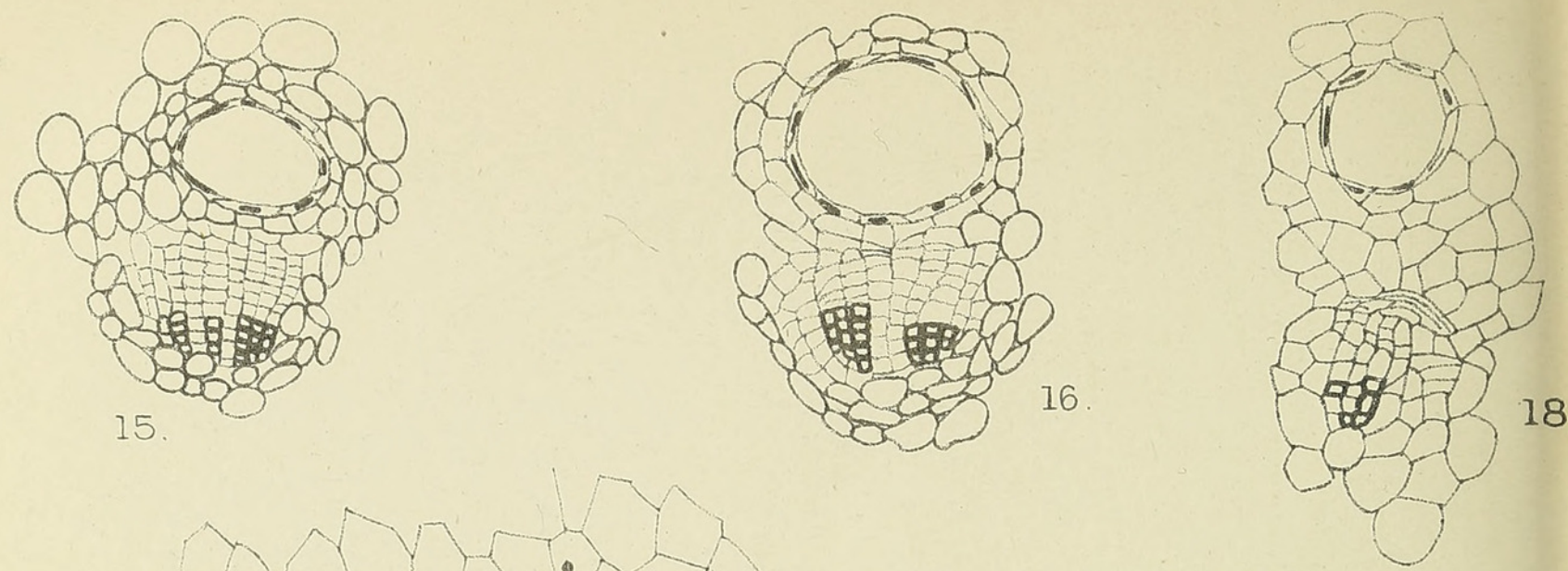

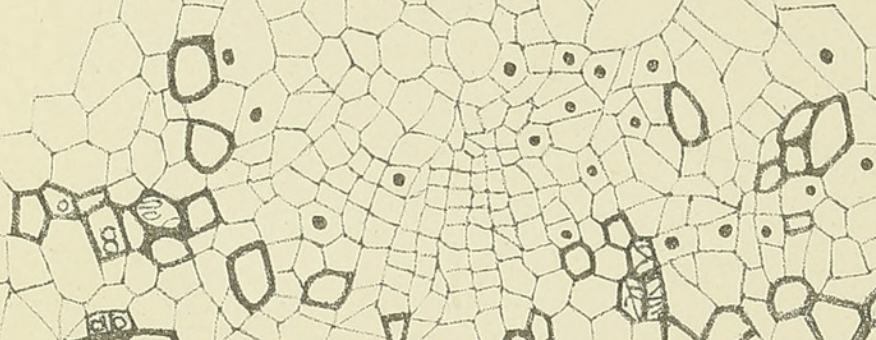

800 D 80 . 00.00

100 $\because \cdot 0$

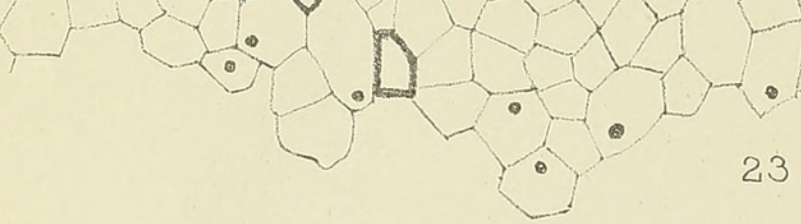

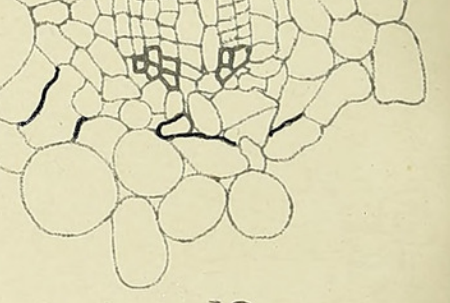

19.
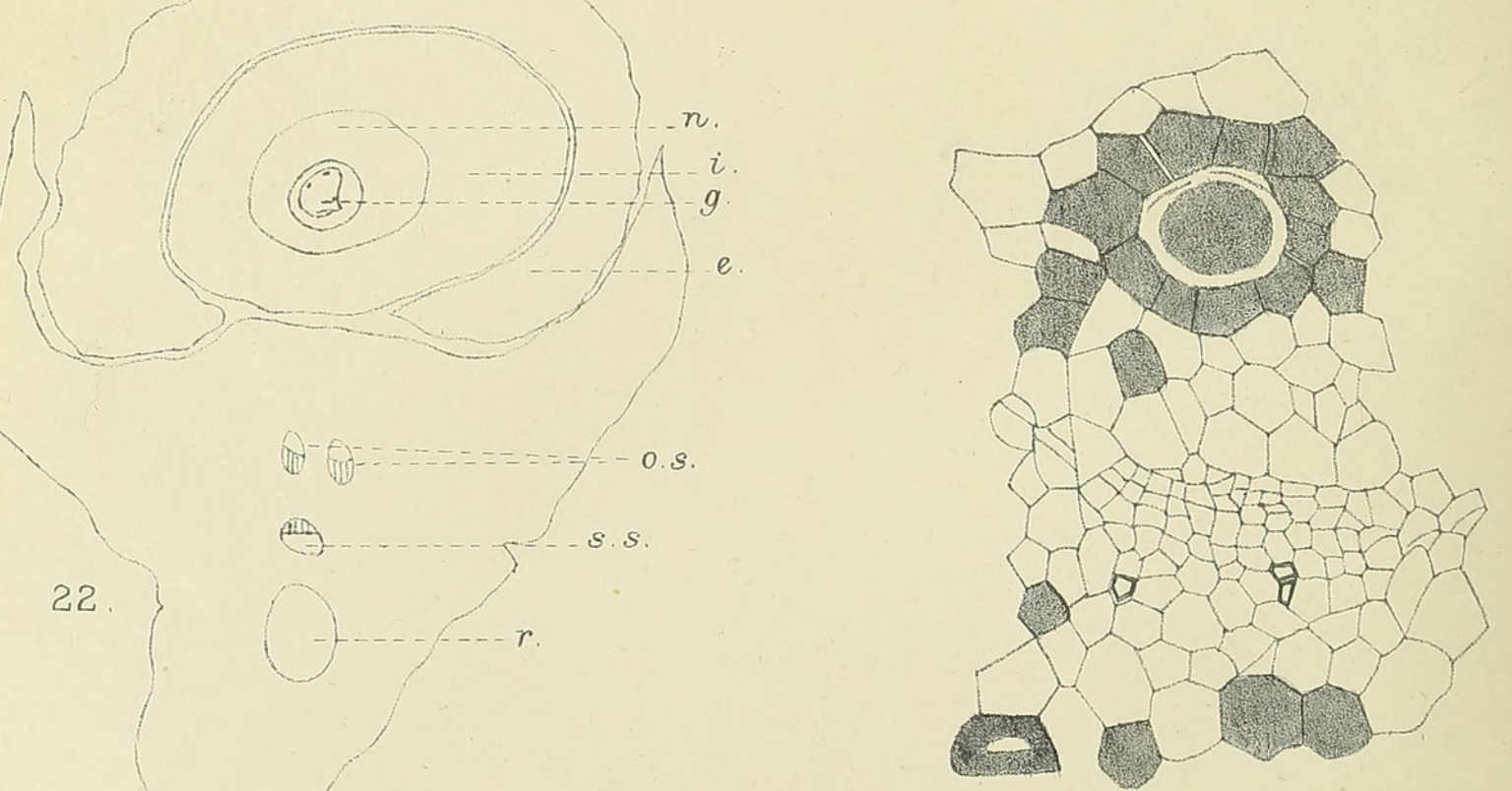

17.

E.J.W. and W.S.del. 

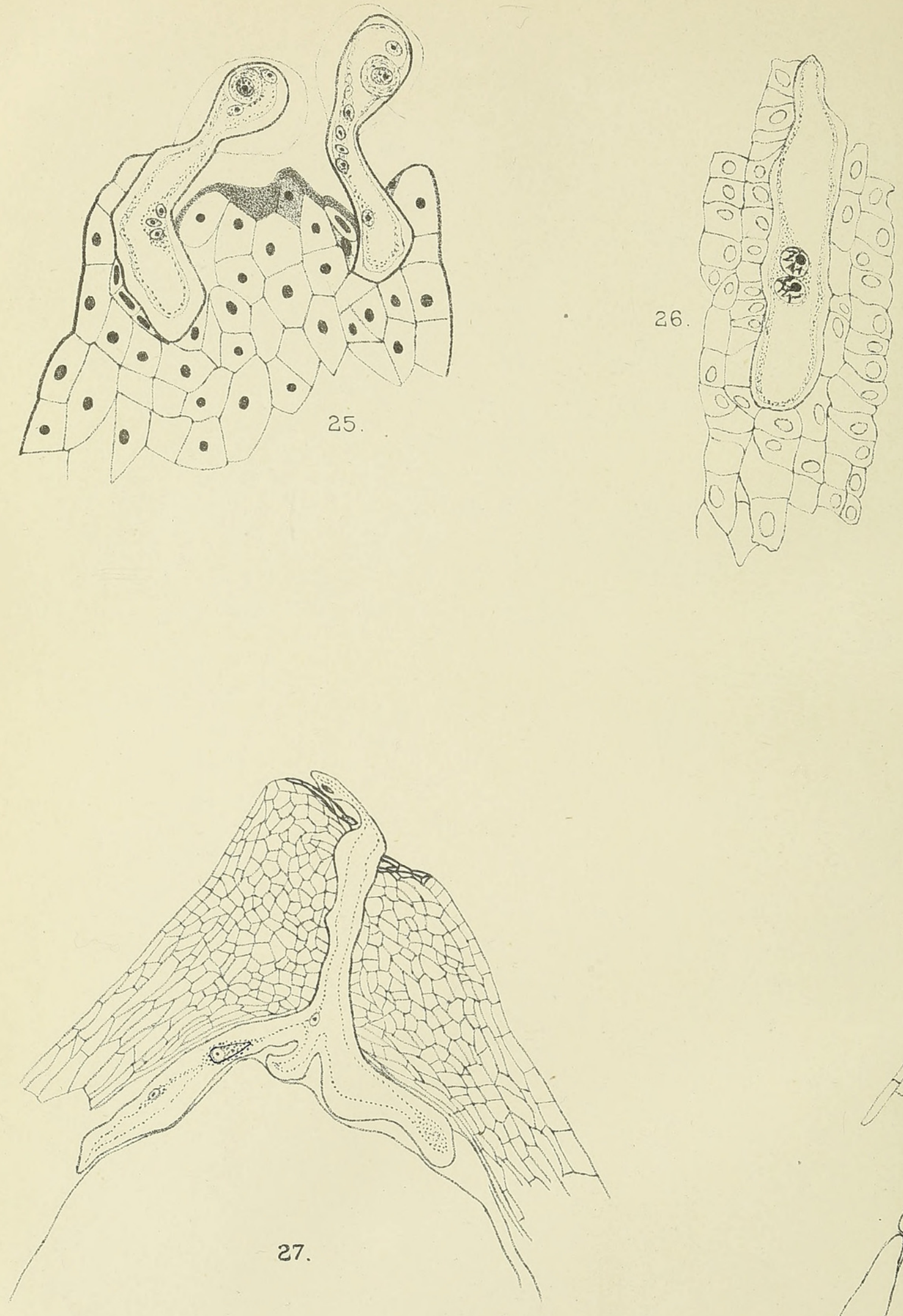

W.S. Ael. 
$6 ?$

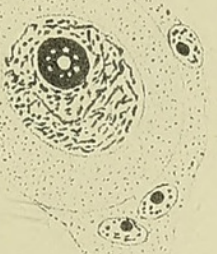

29

(5i)

(5)

30

\section{1}

312

NTh

Anत

सरी

If

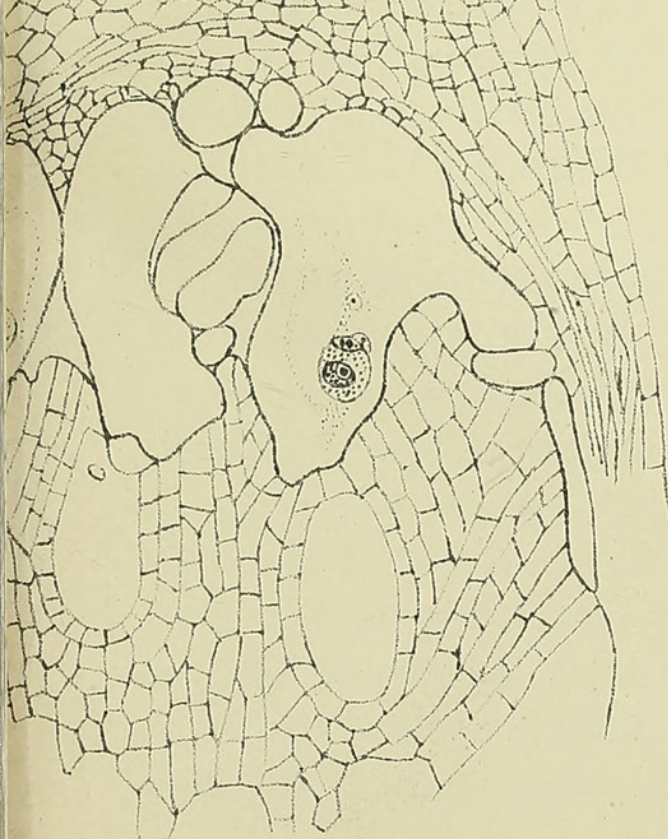

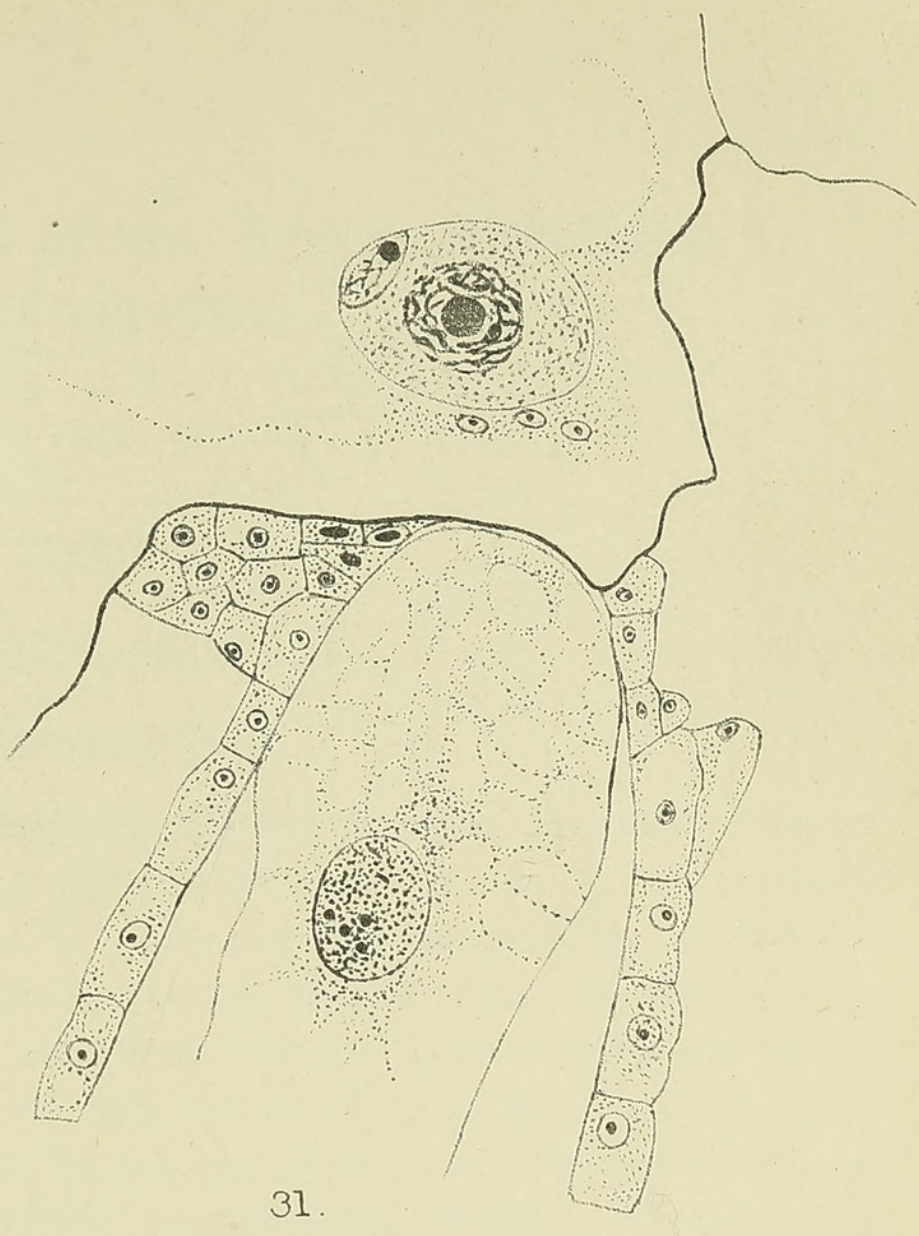

31

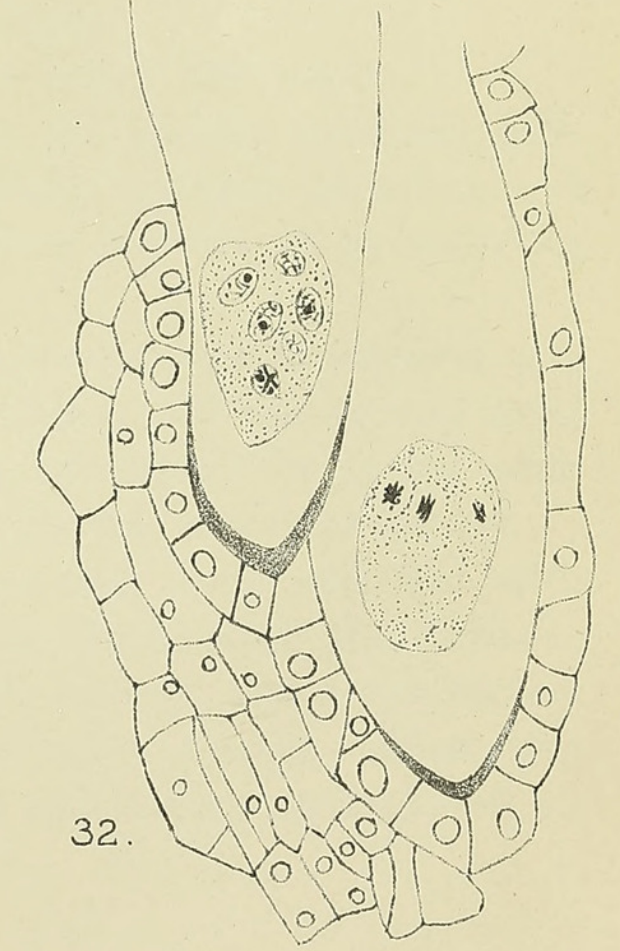

Huth. lith et imp 

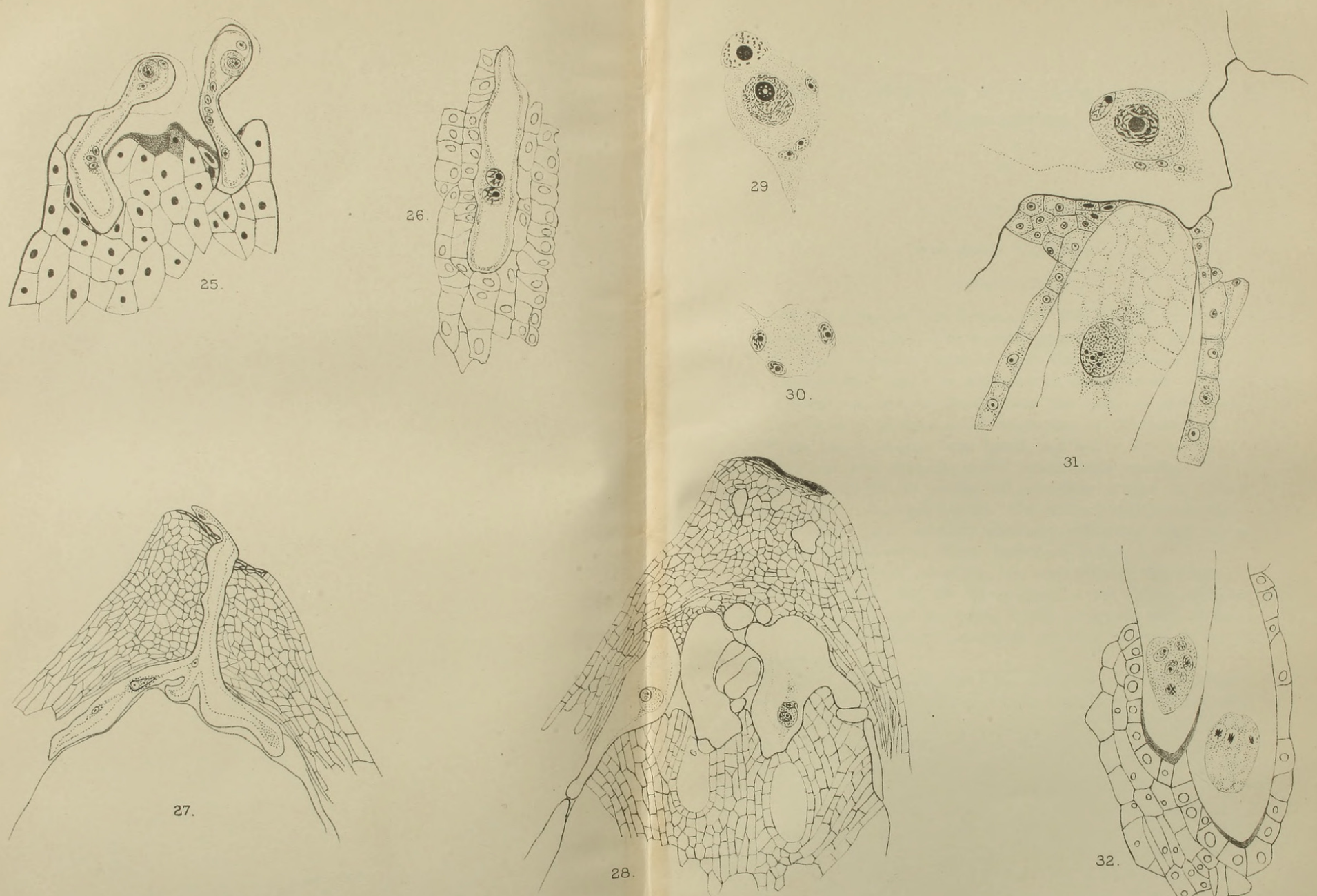


\section{$2 \mathrm{BHL}$ Biodiversity Heritage Library}

Stiles, Walter. 1912. "The Podocarpeae." Annals of botany 26, 443-514. https://doi.org/10.1093/oxfordjournals.aob.a089399.

View This Item Online: https://www.biodiversitylibrary.org/item/236773

DOI: https://doi.org/10.1093/oxfordjournals.aob.a089399

Permalink: https://www.biodiversitylibrary.org/partpdf/319913

\section{Holding Institution}

Smithsonian Libraries

\section{Sponsored by}

Biodiversity Heritage Library

\section{Copyright \& Reuse}

Copyright Status: Not in copyright. The BHL knows of no copyright restrictions on this item.

This document was created from content at the Biodiversity Heritage Library, the world's largest open access digital library for biodiversity literature and archives. Visit BHL at https://www.biodiversitylibrary.org. 